Florida International University FIU Digital Commons

$1-30-2012$

\title{
Three Empirical Essays on Startups' Survival using the Kauffman Firm Survey
}

Mohamad Nassereddine

Florida International University, mnassere@fiu.edu

DOI: $10.25148 /$ etd.FI12042306

Follow this and additional works at: https://digitalcommons.fiu.edu/etd

\section{Recommended Citation}

Nassereddine, Mohamad, "Three Empirical Essays on Startups' Survival using the Kauffman Firm Survey" (2012). FIU Electronic Theses and Dissertations. 573.

https://digitalcommons.fiu.edu/etd/573

This work is brought to you for free and open access by the University Graduate School at FIU Digital Commons. It has been accepted for inclusion in FIU Electronic Theses and Dissertations by an authorized administrator of FIU Digital Commons. For more information, please contact dcc@fiu.edu. 


\section{FLORIDA INTERNATIONAL UNIVERSITY}

Miami, Florida

THREE EMPIRICAL ESSAYS ON STARTUPS' SURVIVAL USING THE KAUFFMAN FIRM SURVEY

A dissertation submitted in partial fulfillment of the

requirements for the degree of

DOCTOR OF PHILOSOPHY

in

ECONOMICS

by

Mohamad Nassereddine 
To: Dean Kenneth G. Furton

College of Arts and Sciences

This dissertation, written by Mohamad Nassereddine and entitled Three Empirical Essays on Startups' Survival using the Kauffman Firm Survey, having been approved in respect to style and intellectual content, is referred to you for judgment.

We have read this dissertation and recommend that it be approved.

Hassan Zahedi

Cem Karayalcin

Sheng Guo

Peter Thompson, Major Professor

Date of Defense: January 30, 2012

The dissertation of Mohamad Nassereddine is approved.

Dean Kenneth G. Furton

College of Arts and Sciences

Dean Lakshmi N. Reddi

University Graduate School

Florida International University, 2012 


\section{DEDICATION}

This dissertation is dedicated to my parents, my sisters, my nephews and nieces. Without my family I would have never been able to finish any chapter of this dissertation. Thank you for providing me with moral support whenever I need it. Thank you for your love. 


\section{ACKNOWLEDGMENTS}

I would like to thank my advisor and committee chair Dr. Peter Thompson, who demonstrated patience and understanding towards my shortcomings, my situations and my person. His support and assistance has helped me tremendously towards reaching the last step of my dissertation journey. He has successfully put in question all the beliefs I had when I first entered the PhD program. He has improved my critical mind and taught me professionalism. Without him I could have never completed this dissertation successfully. Above all, I see him as a mentor for whom I have the upmost admiration.

I wish to thank the members of my committee, Dr. Cem Karayalcin. Dr. Sheng Guo and Dr. Hassan Zahedi for their support, guidance and, most importantly, their critics. I am especially grateful to Dr. Karayalcin for his help in and out of the PhD program. I would like to thank Dr. Sheng Guo for always being available to help whenever I had econometrics issues. I would also like to thank Dr. Hassan Zahedi for his help in statistics.

I would like to express gratitude to all the professors, colleagues and staff of the Department of Economics for always being understanding and ready to help. Thanks to them my experience within the department was relaxed and enjoyable.

Finally, highest appreciation to my father for encouraging me to pursue this $\mathrm{PhD}$. He has always been patient and making this process very comfortable. Special thanks to my mom who has always been protective of me and ready to listen when I needed to talk. My sisters, that I love, supported me and completed this cocoon of security in which I live. Thanks to all my friends from Miami and around the world. 


\section{ABSTRACT OF THE DISSERTATION \\ THREE EMPIRICAL ESSAYS ON STARTUPS' SURVIVAL USING THE KAUFFMAN \\ FIRM SURVEY}

by

Mohamad Nassereddine

Florida International University, 2012

Miami, Florida

Professor Peter Thompson, Major Professor

This dissertation studies newly founded U.S. firms' survival using three different releases of the Kauffman Firm Survey. I study firms' survival from a different perspective in each chapter.

The first essay studies firms' survival through an analysis of their initial state at startup and the current state of the firms as they gain maturity. The probability of survival is determined using three probit models, using both firm-specific variables and an industry scale variable to control for the environment of operation. The firm's specific variables include size, experience and leverage as a debt-to-value ratio. The results indicate that size and relevant experience are both positive predictors for the initial and current states. Debt appears to be a predictor of exit if not justified wisely by acquiring assets. As suggested previously in the literature, entering a smaller-scale industry is a positive predictor of survival from birth. Finally, a smaller-scale industry diminishes the negative effects of debt.

The second essay makes use of a hazard model to confirm that new service-providing (SP) firms are more likely to survive than new product providers (PPs). I investigate the possible explanations for the higher survival rate of SPs using a Cox proportional hazard model. I examine six hypotheses (variations in capital per worker, expenses per worker, owners' experience, industry wages, assets and size), none of which appear to explain why SPs are more likely than 
PPs to survive. Two other possibilities are discussed: tax evasion and human/social relations, but these could not be tested due to lack of data.

The third essay investigates women-owned firms' higher failure rates using a Cox proportional hazard on two models. I make use of a never-before used variable that proxies for owners' confidence. This variable represents the owners' self-evaluated competitive advantage.

The first empirical model allows me to compare women's and men's hazard rates for each variable. In the second model I successively add the variables that could potentially explain why women have a higher failure rate. Unfortunately, I am not able to fully explain the gender effect on the firms' survival. Nonetheless, the second empirical approach allows me to confirm that social and psychological differences among genders are important in explaining the higher likelihood to fail in women-owned firms. 


\section{TABLE OF CONTENTS}

CHAPTER

PAGE

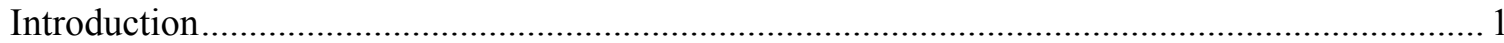

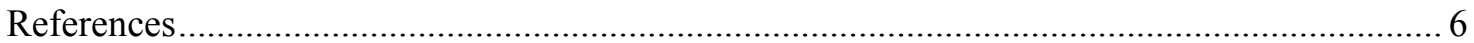

Chapter 1 Startups Survival Analysis using the Kauffman Firm Survey: An Analysis of

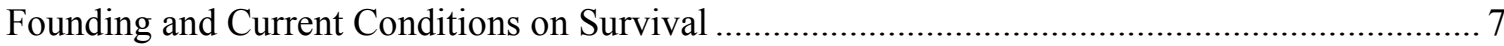

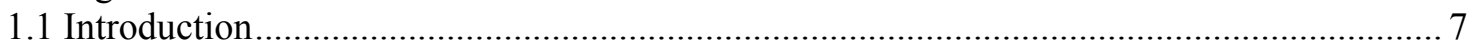

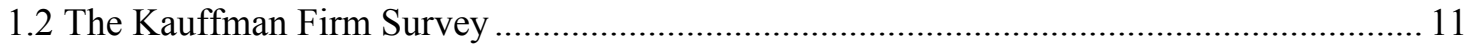

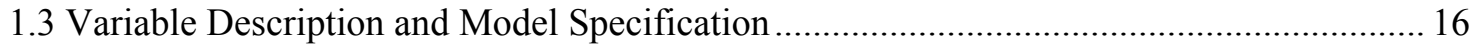

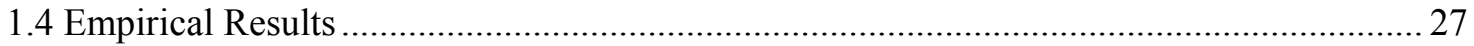

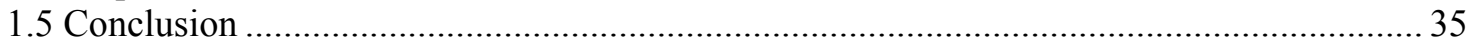

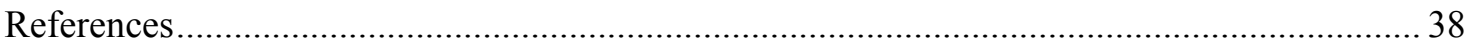

Chapter 2 Firms' Survival within the Product-Service Spectrum using the KFS: How the Choice

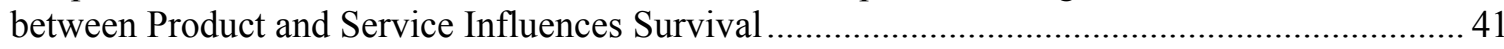

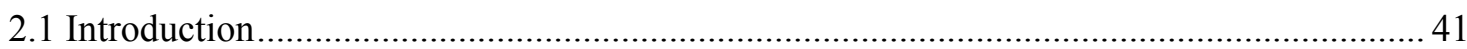

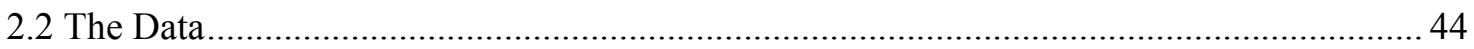

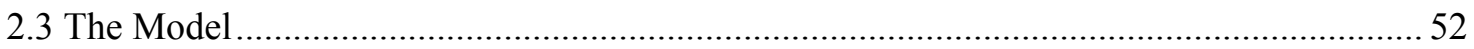

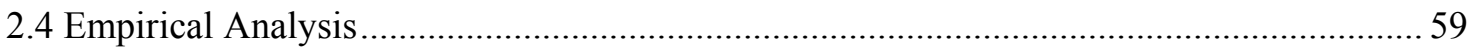

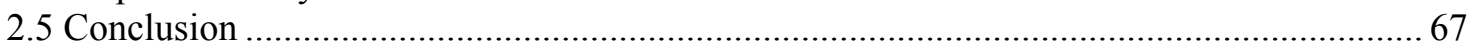

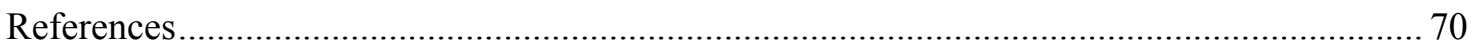

Chapter 3 Why are Women-Owned Firms Associated with Higher Failure Rates? A Cross Gender

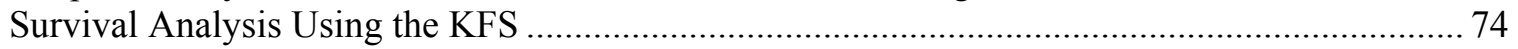

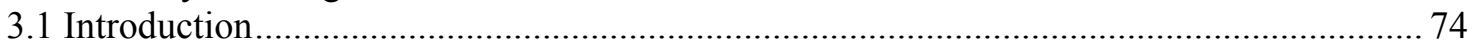

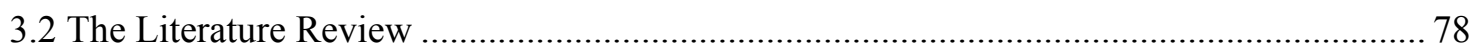

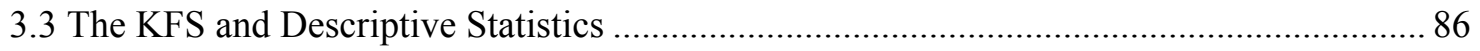

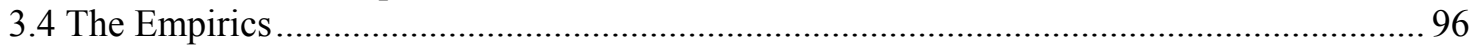

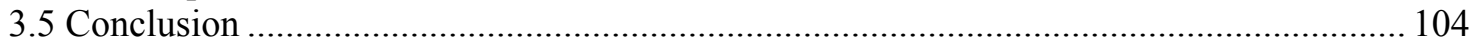

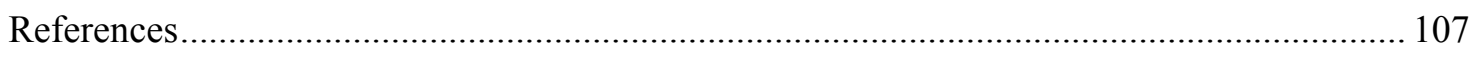

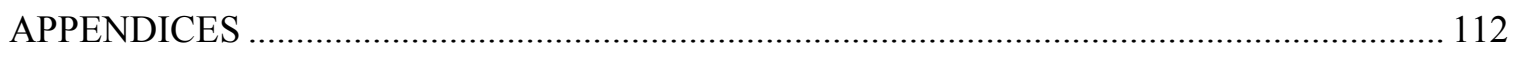

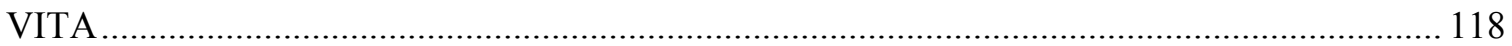




\section{LIST OF TABLES}

TABLE

PAGE

Table 1.1 Firms' Outcomes (2004-2007) in Percentages ........................................................... 13

Table 1.2 Firms'Distribution by Industry in Percentages ........................................................... 14

Table 1.3 Distribution of Firms by Employment Size Category in Percentages .......................... 15

Table 1.4 Percentage in Two-digit Industries with Fewer than 20 Employees in 2004 ............... 20

Table 1.5 Regressions of Survival in 2005 using 2004 Control Variables ................................. 28

Table 1.6 Regressions of Survival in 2006 using 2005 Control Variables ................................... 30

Table 1.7 Regressions of Survival in 2007 using 2006 Control Variables .................................. 32

Table 1.8 Regressions of Survival in 2006 using 2004 Control Variables ................................... 33

Table 1.9 Regressions of Survival in 2007 using 2004 Control Variables .................................. 35

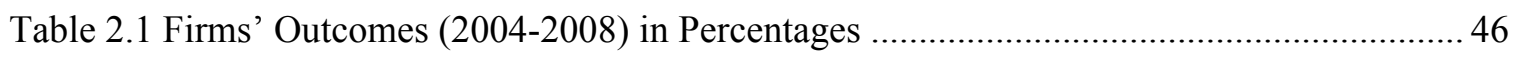

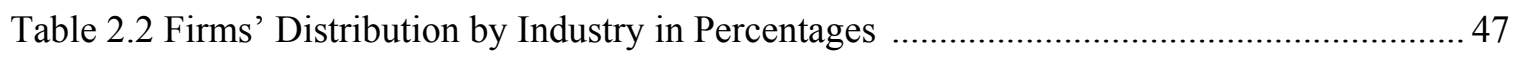

Table 2.3 Distribution of Firms by Employment Size Category in Percentages .......................... 49

Table 2.4 The Sample of the Surviving Population by Provider Categories in Percentages ......... 50

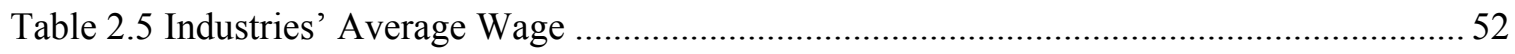

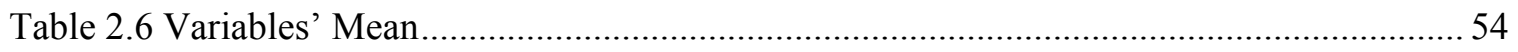

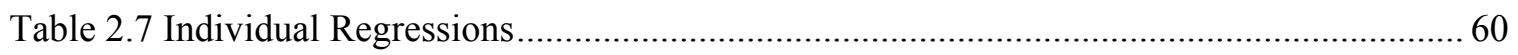

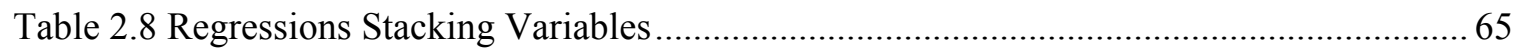

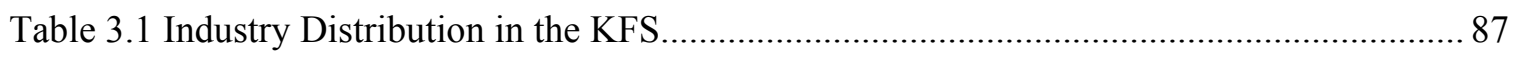

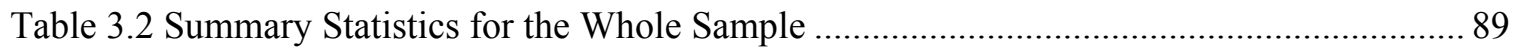

Table 3.3Summary Statistics Comparison between Genders .................................................. 93

Table 3.4 Women-Owned Firms' Industry Distribution........................................................ 95

Table 3.5 Men-Owned Firms' Industry Distribution ............................................................... 96

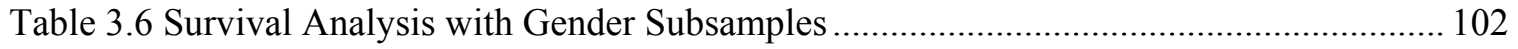


Table 3.7 Survival Analysis for the Gender Effect using Intereaction Variables... 


\section{INTRODUCTION}

Economic sustainability and growth rely heavily on individuals' ability and desire to become entrepreneurs. According to the Small Business Administration (SBA), small businesses comprise 99.7 percent of all employer firms in the U.S. economy. Needless to say, policies designed to accommodate entrepreneurship and small businesses creation are necessary in order to get the economy out of a recession and motivate job creation. Recently, President Obama unveiled an economic plan to reduce unemployment by motivating job creation in the private sector.

However, the recent economic downturn has pushed many companies out of business and firms' survival studies are now needed more than ever to comprehend what factors contribute to firms' survival in order to give small businesses a chance to remain in business and create jobs.

The recent release of the Kauffman Firm Survey (KFS), a longitudinal dataset that follows newly founded firms on a yearly basis, provided an opportunity to review previous findings and contribute to the literature with new findings. This entire dissertation makes use of the KFS to investigate three questions related to firm survival.

The first essay analyzes the effects of a firm's current and founding conditions on its survival. Prior to this research, studies such as Audretsch and Mahmood (1994) and Åstebro and Bernhardt (2003) have reported evidence of the non-negligible effects of founding conditions on a firm's survival ability.

This motivates the question of why there is a lack of studies comparing current to founding conditions' effects on firms' survival. To the best of my knowledge this question has yet to be addressed. Moreover, previous studies lacked adequate data. For example, Åstebro and Bernhardt (2003) used the "Characteristics of Business Owners", which imposes a five-year gap on the data waves. Other studies restricted their analysis to specific industries. The release of the KFS allows me to remediate these data issues. 
I attempt to answer the question stated above through an empirical approach. Thus, using probit models, I investigate the effects of variables in the literature that have been found to affect firms' survival. On the one hand, the effects of current conditions are estimated using the probability of survival at time $t$ using the independent variables measure at $t_{t-1}$. On the other hand, the founding conditions effects represent the probability of survival at time $t$ using the variable measure at $t_{0}$.

The literature has previously documented unambiguous positive effects of size (Geroski, Mata and Portugal 2010; Mata and Portugal 1994) and experience (Thompson 2005; Klepper and Simons 2003) on survival. I follow the literature and control for these variables as well. Additionally, Audretsch and Mahmood (1994) confirm the importance of industry measures to control for the environment of the firm. Thus, an industry dummy allows me to control for the scale of operation within the industry that a firm operates in. Last, I add financial leverage dummies to the model. Firms' debt over assets ratio is calculated and attached to a corresponding dummy measure $(0$, lower than 1,1 , greater than 1 and infinite). Previously, studies such as Cooley and Quadrini (2001) claimed that debt was a determinant of failure. Åstebro and Bernhardt (2003), however, claim that survival probability was increasing with external initial debt.

The first chapter results allow me to reiterate the importance of size and experience on firms' survival. Moreover, I find that the effects of size are greater in the current conditions, while the effects of experience are more important at foundation. Also, leverage seems to decrease the firms' survival prospects when the debt is not used to acquire assets. These results on leverage hold true both in the current and founding conditions. Finally, the industry scale measure seems to matter at entrance only (foundation). Firms entering a smaller-scale industry are more likely to survive. 
The second essay examines which side of the product-service spectrum is most likely to contribute to firms' survival. That is, firms need to make the decision at startup to be a service provider(s) (SP), a product provider(s) (PP) or a provider of both services and products (PB). I am not aware of any study in the literature that tackles firms' survival from this perspective. This essay was motivated by the hole found in the literature and thus represents an attempt to better understand which factors motivate firms' survival.

The survival analysis is conducted using a Cox proportional hazard model. The first goal of the paper is to provide proof that one side of the product-service spectrum is indeed more likely to survive than the other. I focus the study on SPs and PPs. The firms were part of the KFS in which firms respondents were asked if they provide services, products or both. Thus, each firm was associated with a dummy variable. The results indicate that SPs were associated with lower failure. In a continuing endeavor, I test six hypotheses (which could explain the hazard rate behavior). The survival associated with being an SP or a PP is tested using these hypotheses first individually and then by successively adding them. The hypotheses (capital per worker, expenses per worker, owners' experience, size, assets and industry wage) are stated using the variables on which SPs and PPs differ the most, together with the literature on firms' survival.

The study provides insights on factors that could promote PPs' and SPs' survival. For instance, I find that capital per worker is the most important contributor to PPs' survival ability. I also find that an increase in assets increases PPs' failure rates once size is controlled for. Unfortunately, I am not able to explain empirically the reasons behind PPs' higher failure rates. Thus, I suggest that SPs' higher ability to evade taxes and customers' retention ability should be the next hypotheses to be tested.

The third essay contributes to the owners' gender firms' survival literature. There are disagreements among researchers on whether women-owned firms are more likely to fail. On the one hand, a majority of the research (Boden and Nucci 2000; Carter, Williams and Reynolds 
1997) confirms that women-owned firms are associated with higher failure rates. On the other hand, papers such as Kalleberg and Leicht (1991), found no negative effects of gender on survival.

An overwhelming number of studies have tried to explain the gender effect on survival through variables on which women-and men-owned companies differ greatly. The variables mostly represented human capital measures, industry of operation, firm's size and financial capital structure. However, evidence suggests that differences across genders exist as well at social and psychological level.

The KFS provides two variables that could be used as proxies for social and psychological measures. The first one is home-operated businesses. Women tend to be more likely to operate their businesses from home, and Boden and Nucci (2000) reported that businesses operating from home use less financial capital at startup. Furthermore, Boden and Nucci found that startup financial capital was positively linked to business survival. Owners' were asked by the Kauffman Foundation if they believed they had a competitive advantage. Thus, I use this self-reported judgment variable as a proxy of owners' confidence.

I use the home-operated dummy and the competitive advantage dummy, along with other measures found in the literature (size, experience, debt and equity), within two survival models with Cox specifications. The first model is used on both women- and men-owned firms' subsamples. I find that women have better coefficients for survival on most variables, indicating that the gender effect on firms' survival is most probably the result of differences within these variables. For instance, women may benefit from a greater effect on survival from hiring a marginal employee, but men have more employees. Competitive advantage, however, seem to be more beneficial to men. After confirming that women-owned companies within the KFS were more likely to fail, I pursue my investigation and add the variables successively with the corresponding gender's interaction variables. Although I was not able to completely explain the 
gender effect on firms' survival, the last model—which adds the competitive advantage dummy - indicates that psychological differences among genders are an important factor in explaining women-owned firms' higher failure rates. 


\section{REFERENCES}

Audretsch, D.B. \& Mahmood, T., 1994. The rate of hazard confronting new firms and plants in U.S. manufacturing. Review of Industrial Organization, 9(1), pp.41-56.

Åstebro, T. \& Bernhardt, I., 2003. Start-up financing, owner characteristics, and survival. Journal of Economics and Business, 55(4), pp.303-319.

Boden JR., R.J. \& Nucci, A.R., 2000. On the survival prospects of men's and women's new business ventures. Journal of Business Venturing, 15(4), pp.347-362.

Carter, N.M., Williams, M. \& Reynolds, P.D., 1997. Discontinuance among new firms in retail: The influence of initial resources, strategy, and gender. Journal of Business Venturing, 12(2), pp.125-145.

Cooley, T.F. \& Quadrini, V., 2001. Financial markets and firm dynamics. American Economic Review, pp.1286-1310.

Geroski, P.A., Mata, J. \& Portugal, P., 2010. Founding conditions and the survival of new firms. Strategic Management Journal, 31(5), pp.510-529.

Kalleberg, A.L. \& Leicht, K.T., 1991. Gender and Organizational Performance: Determinants of Small Business Survival and Success. The Academy of Management Journal, 34(1), pp.136-161.

Klepper, S. \& Simons, K.L., 2003. Dominance by birthright: entry of prior radio producers and competitive ramifications in the US television receiver industry. The SMS Blackwell Handbook of Organizational Capabilities: Emergence, Development, and Change, pp.1542.

Mata, J. \& Portugal, P., 1994. Life duration of new firms. The Journal of Industrial Economics, 13, pp.227-245.

The Office of Advocacy. 2011. Frequently Asked Questions. The U.S. Small Business Administration. Available at: http://www.sba.gov/sites/default/files/sbfaq.pdf.

Thompson, P., 2005. Selection and firm survival: Evidence from the shipbuilding industry, 18251914. Review of Economics and Statistics, 87(1), pp.26-36. 


\section{CHAPTER 1}

\section{Startups Survival Analysis using the Kauffman Firm Survey: An Analysis of Founding and Current Conditions on Survival.}

\subsection{Introduction}

This paper reports the results of a study of the effects of current and founding conditions on firm survival using the Kauffman Firm Survey (KFS). We know from prior work that a firm's founding conditions have persistent effects on its survival and growth (Mata and Portugal 1994, Mata et al. 1995, Audretsch and Mahmood 1994, Carroll et al. 1996, Åstebro and Bernhardt 2003, Huynh et al. 2008, Geroski et al. 2010), but data limitations have left us with many unanswered questions.

Empirical research on survival or growth requires a dataset with three characteristics: a large sample containing a large range of sizes, firms that are followed from birth and short intervals between follow ups. Before the KFS, research on firm dynamics were conducted on databases each lacking one or more of the needed characteristics. For example, Åstebro and Bernhardt (2003) use a sample of firms taken from the "Characteristics of Business Owners" (CBO), a survey published by the US Census in 1982, 1987 and 1992. The study was conducted on a sample from the survey of new firms created in 1987 and the sample is checked again in 1992, a five year gap, to determine who survived. A five-year gap is a large gap in time, enough to suggest that their results could be improved. Some of the firms found dead in 1992 could have died in 1988 or later.

The Kauffman Firm Survey is a new panel dataset on firms created in 2004, and firms are followed consistently every year. The KFS has all the needed characteristics and presents a bonus. It surveys a large range of industries. This paper contributes to the literature by filling some of the gaps brought about by the lack of data availability regarding the different firm and 
industry specific variables. I use the KFS to check on the reliability of past research conducted in the literature by studying the current state effects on survival together with the initial state.

Growth and survival analyses have been relatively well covered in the literature on firm dynamics. Both areas share common variables such as size ${ }^{1}$, experience and owners' characteristics just to cite a few. Gibrat's Law ${ }^{2}$ states that a firm's growth rate is independent of its size. Past studies have provided empirical evidence suggesting that Gibrat's Law could be wrong or at least wrong to some extent (Kumar 1985, Evans 1987, Hall 1987). Hall (1987) rejects Gibrat's law for small firms although she accepts the law for larger firms. Evans (1987) shows that the growth rate and its variance are negatively correlated with a firm's size and age. Evans also reported that survival was increasing with age, a result found in other studies (Dunne et al. 1989). Evans reinforced Hall, confirming that Gibrat's Law was indeed holding for larger firms. Dunne et al. (1989) conducted their study on the growth and failure of manufacturing plants. Their results suggested that failure rates decline with plant size and age.

Few models have been developed to explain these age effects. Among them, Cooley and Quadrini (2001) is notable. Cooley and Quadrini (2001) added a theoretical model of size (equity) and age effects on firm's dynamics, providing a significant contribution to the firm's dynamics literature. They differentiate their contribution from previous research by taking both size and age dependency into consideration simultaneously, after introducing financial frictions into the model. Cooley and Quadrini claim that debt matters and is a cause of failure. The model depicted by Cooley and Quadrini predicts that younger firms tend to take on more debt which in turn increases the volatility of their profits, thus increasing their failure rate.

\footnotetext{
${ }^{1}$ The empirical literature has been more developed on the subject with papers such as Dunne et al. (1989); Mitchell (1994), Audretsch and Mahmood (1994), Haveman (1995), Geroski et al. (2010) Huynh et al. (2008). Theoretically, on the other hand, size effects on growth and survival is harder to find. Jonavovic (1982), a reference, assumes that initial size does not matter and current size includes all the information on the firm history allowing survival or exit. This is contrary to some of the empirical findings cited above reporting the importance of initial size for survival.

${ }^{2}$ See Sutton (1997).
} 
Although the age hypothesis cannot be tested directly using the KFS (all firms are part of the same cohort together with the KFS being a relatively new dataset), it is tested for indirectly through the debt hypothesis. Financial conditions (debt, equity and leverage) have also been a critical part of firms' dynamics in the literature and the KFS offers a full range of data available at every life stage of the financial health of the company. Cooley and Quadrini also found that leverage (described as debt over equity) was decreasing with firm's size because smaller firms take on more debt. Relating these findings to the size and survival literature (probability of exit decreases with size), I can assume that the probability of exit should be decreasing with leverage. Åstebro and Bernhardt (2003) studied the initial financing conditions of the firm effects on survival. They argue that probability of survival is increasing with initial external debt, although a negative correlation exists between initial bank loans and survival. On the other hand, Huynh et al. (2008) suggest that a firm's exit probability is increasing with leverage ${ }^{3}$.

I test for the effects of quality using years of experience in the industry, as suggested by Thompson (2005). A literature promoting experience as an important contributor to survival has been developed. Research has tackled two main areas pertaining to firms' experience. First, past studies ${ }^{4}$ find the effects on owners' pre-entry experience to be a persistent determinant of performance in the years following entry. Second, the more related the experience is to the industry in which the firm operates the more valuable it is. Thompson studies both effects in the shipbuilding industry and his findings reinforce Klepper and Simons' (2000) suggestion that firms with more experience in related fields of the industry perform better than de novo entrants with less experience.

${ }^{3}$ Huynh et al. (2008) describe leverage as debt over assets. Exit is increasing with the leverage variable and therefore with debt value relative to asset value (leverage $=$ debt /assets). This is the definition I use in the paper. This confirms the results found by Cooley and Quadrini (2001).

${ }^{4}$ Carroll et al. (1996), Jovanovic and Rousseau (2001). 
Firm-specific characteristics are not the only major predictors of survival and growth. The environment in which the firm operates is also significant. Audretsch (1991), and Audretsch and Mahmood (1994) emphasize the need to consider the industry together with firm characteristics. I introduce a dummy representing the scale of the industry in which the firm operates. The minimum efficient scale (MES) specific to an industry could be an important determinant of survival. Growth constraints indicate that the higher the scale of the industry the more difficult it is for firms to reach the MES.

I make use of probit regressions, which allows me to estimate the effects of current and initial conditions on the firm's survival in the following period for every year the firm stays alive. The current conditions' effects on survival are estimated, letting me determine how the state of the company during a year affects its survival next year. The initial state effects are obtained the same way but only regressing on founding conditions variables. On one hand, the study finds that size is a more important positive predictor of survival in the current condition although I do find the founding conditions to be a significant positive predictor of survival as well. On the other hand, the relevance of owners experience is a more important positive predictor of survival in the founding stage. Current relevant owners' experience is also found to be a positive contributor to survival. Both stages associate diminishing returns to relevance of owners' experience.

The probability of survival seems to be decreasing with leverage. The companies that have negative equity seem to be the most prone to exit. Evidently, a firm needs to use the debt it owes adequately or debt will drive the firm to exit. Entering a lower scale industry seems to increase the probability of survival and the results are significant in the first year and in the years following entrance. It is the choice of entrance into an industry that is significant as opposed to the yearly activity in a low scale industry. Moreover, entrance in a low scale industry decreases the negative effect of debt. 
The first section of the paper describes the Kauffman Firm Survey and provides summary statistics on the full dataset. The second section introduces the variables used, in addition to providing a description of three different models. A brief literature review accompanies the model descriptions. The third section presents the results in two parts. The first part analyses the current year condition on survival and the second part adds the effects on survival of initial condition. Finally, I conclude the paper with a summary of the findings and a discussion for future research possibilities.

\subsection{The Kauffman Firm Survey}

I use the public release of the KFS, a panel data set covering a broad range of topics, allowing the study of a sample of firms created in 2004. The dataset contains information on a variety of topics including financing, organizational structure and legal status, business characteristics and strategy, owners demographics and work behavior.

The KFS is based on a random sample of businesses--from the Dun and Bradstreet (DB) database - created in 2004. The questionnaires sent to the sample were designed by the Mathematica Policy Research. The baseline questionnaire was sent in 2004 and due to the quest for a longitudinal database, follow-up questionnaires were sent every following year. So far adding to the baseline are three following waves consisting of 2005, 2006 and 2007 data.

'The development and change aspects involved with innovations in high-tech industries motivated the Foundation to oversample firms in these fields. The screening/eligibility test allowed only 15 percent of the potential pool of firms to be part of the sample. The initial sample of firms passed "the eligibility test" defining a new business in 2004 and consisted of 4,928 firms out of an initial pool of 32,429 businesses. Respondents were paid $\$ 50$ to answer using a selfadministered web survey or a computer-assisted telephone interview.

Eligibility was determined with two tests. A firm had to be a new company and it had to be a company created individually by de novo entrepreneurs. The first test ensures that the 
company had started its activity in 2004. Therefore, if the firm had started activity in 2003 (or earlier) under any other form of structure and the 2004 initial year of activity for example only marked a restructuring (e.g., sold business, renamed business, or change in activity), the firm did not qualify to be part of the sample. The second test checked ownership and provenance of the firm. It could not be a subsidiary of any other business, could not have been a spin off, nor inherited by previous owners. Finally, it could not be a not-for-profit company. Firms that passed both tests were part of the sample in the baseline questionnaire and follow ups. The baseline questionnaire records data at the birth of the firm, and therefore is used as the initial conditions of operation in the study.

As previously stated, there are four waves available in the current Kauffman Firm Survey. Firms that participated in the first wave satisfied two conditions. They first needed to be part of the baseline sample, and needed to have survived the first year of activity. The first wave found that 7.4 percent ( 6 percent plus 1.4 percent) of the 4,928 (369) were out of business by the end of 2005 (see Table 1.1). There were 4,523 businesses left in 2005. More businesses were found have closed by the time of the second and third follow ups. Some of the surviving firms chose not to answer and sample weights were adjusted accordingly.

The possible reasons for exit were determined at the beginning of the survey. Firms that ceased operation temporarily were a small minority in the sample. In the first year 3 percent of the sample temporarily ceased operation, 3.1 percent in the second and 1.7 percent in the third year. I exclude those firms from the study because the survey extends four years. A firm described as active in any year had to have been described as active in all previous years. A firm that ceased operation temporarily (for example one that exits in 2005 and is seen as reappearing in 2007) is dropped from the sample (36 observations were dropped). 
Any reason that will bring the respondents to declare that the same original business is no longer in operation, with at least one of the original founders is defined as inactive in my study ${ }^{5}$. Hence, businesses that were sold or that merged with other businesses were also described as closed because of the change in ownership. Only 1.4 percent of the businesses were sold or merged the first year, compared with 1.3 percent and 0.8 percent respectively in the second and third years.

Table 1.1

Firms' Outcomes (2004-2007) ${ }^{6}$ in Percentages

\begin{tabular}{|lccc|}
\hline Year & $\mathbf{2 0 0 5}$ & $\mathbf{2 0 0 6}$ & $\mathbf{2 0 0 7}$ \\
Survived & 89.6 & 80.2 & 73.4 \\
Closed operations & 6.0 & 14.0 & 21.4 \\
Sold to or merged with another business & 1.4 & 2.7 & 3.5 \\
Temporarily ceased operations or other & 3.0 & 3.1 & 1.7 \\
$\quad$ TOTAL & 100.0 & 100.0 & 100.0 \\
\hline
\end{tabular}

Source: Kauffman Firm Survey Microdata. Sample includes only surviving firms over the 2004-2007 period, and firms that have been verified as going out of business over the same period. The original sample size in 2004 was 4,928 .

Some firms were reported to have no owner in 2004, 2005, 2006 and 2007, and were dropped from the sample (respectively, 41, 22, 23 and 16 observations were deleted). Some firms surveyed could also be firms created to reduce taxes on an individual. It has been shown in prior research, both theoretical and empirical (Gordon 1998, Åstebro and Bernhadt 2003), that paying fewer taxes could be an incentive for individuals to create companies as a tax shelter because corporate tax rules are often advantageous compared to income tax. Hence, I expect some of the firms surveyed were also created as tax shelters. The way I chose to correct for this issue was to drop the firms that reported no sales in all years of activity (58 observations were deleted).

\footnotetext{
${ }^{5}$ Hall (1987) considers mergers as the exit of two firms and the creation of a new firm. The creation of a new firm is irrelevant in my study.

${ }^{6}$ From A. Robb et al. "An overview of the Kauffman Firm Survey", Results from the 2004-2007 Data", 2009
} 
Table 1.2

Firms' Distribution by Industry ${ }^{7}$ in Percentages

\begin{tabular}{|c|c|c|c|}
\hline Industry names and (code) & $\begin{array}{l}\text { KFS New } \\
\text { Employer } \\
\text { Businesses }\end{array}$ & $\begin{array}{l}\text { Census } \\
\text { Employer } \\
\text { Firm } \\
\text { Births }\end{array}$ & $\begin{array}{l}\text { PSED } \\
\text { New } \\
\text { Businesses }\end{array}$ \\
\hline $\begin{array}{l}\text { Professional (54), } \\
\text { Management, and Educational Services (61) }\end{array}$ & 15.5 & 14.1 & 16.1 \\
\hline Retail Trade (44) & 15.6 & 12 & 18.6 \\
\hline $\begin{array}{l}\text { Administrative and Support, and Waste } \\
\text { Management and Remediation Services (56) }\end{array}$ & 11.4 & 6 & 2.1 \\
\hline Construction (23) & 9.8 & 15.7 & 10 \\
\hline Other Services (except Public Administration) (81) & 8 & 8.5 & 0.3 \\
\hline Manufacturing (31) & 7.2 & 3.2 & 3.5 \\
\hline Wholesale Trade (42) & 6 & 4.5 & 1.5 \\
\hline Real Estate, Rental and Leasing (53) & 3.7 & 5.1 & 5.3 \\
\hline Finance and Insurance (52) & 4.7 & 2.2 & 3.1 \\
\hline Health Care and Social Assistance (62) & 4.2 & 7.7 & 2.9 \\
\hline Information (51) & 2.6 & 1.4 & 4.2 \\
\hline Transportation and Warehousing (48) & 2.9 & 3.3 & 2.4 \\
\hline Arts, Entertainment, and Recreation (71) & 3.1 & 2.1 & 3.2 \\
\hline Accommodation and Food Services (72) & 3.9 & 9.1 & 10.9 \\
\hline Agriculture, Forestry, Fishing, and hunting (11) & 1.4 & 0.4 & 2 \\
\hline Mining (21) & 0 & 0.3 & 0.5 \\
\hline Utilities (22) & 0 & 0.1 & 0.5 \\
\hline Management of Companies and Enterprises (55) & 0 & 0.1 & 6.7 \\
\hline Unclassified (99) & 0 & 2.2 & 5.6 \\
\hline
\end{tabular}

Source: Kauffman Firm Survey, Baseline data: Tabulations by Mathematica Policy Research, Inc; and Office of Advocacy, U.S. Small Business Administration, from longitudinal data (established with some first-quarter payroll) provided by the U.S. Census Bureau; Reynolds, P. 2004. Entrepreneurship in the United States Assesment, Miami, Fla: Florida International University.

The distribution of firms by industry shows by comparison to the U.S Census that the KFS has a higher proportions of businesses in many industries such as manufacturing, professional management, education, retail and wholesale, finance and insurance, just to cite a few. However, the KFS has a lower proportion of firms in construction, health care and social assistance, and accommodation and food services (see Table 1.2).

\footnotetext{
${ }^{7}$ From A. Robb et al. "An overview of the Kauffman Firm Survey", Results from the 2004-2007 Data", 2009
} 
The sample surveyed shows that the majority of firms start as small with fewer than 5 employees (75.1 percent). Also, the distribution of firms by size shows similarities with the Census. For example, 10.35 percent of the KFS sample start with 10 or more employees, compared to 10.4 percent $^{8}$ in the Census. Table 1.3 also shows that the KFS was not able to capture any firm in its sample with 500 employees or more. The Foundation suggests this could be because few firms have the capacity to begin at such a large scale. Note that the number of small firms with fewer than 5 employees and the ones with 20 or more employees are a bigger part of the distribution by 2007. On the other hand, firms with 5 to 19 employees are a smaller part of the distribution by 2007 .

Table 1.3

Distribution of Firms by Employment Size Category ${ }^{9}$ in Percentages

\begin{tabular}{|ccc|}
\hline Number of Employees & All firms in 2004 & All surviving Firms in 2007 \\
$\mathbf{1 - 4}$ & 75.1 & 76.7 \\
$\mathbf{5 - 9}$ & 14.6 & 13.0 \\
$\mathbf{1 0 - 1 9}$ & 6.6 & 6.0 \\
$\mathbf{2 0 - 9 9}$ & 3.4 & 3.8 \\
$\mathbf{1 0 0 - 4 9 9}$ & 0.3 & 0.4 \\
$\mathbf{5 0 0 +}$ & 0.0 & $0.0^{10}$ \\
\hline
\end{tabular}

Source: Kauffman Firm Survey, Baseline data; Office of Advocacy, U.S. Small Business Administration, Statistics of U.S. businesses, U.S. Census, 2004.

The KFS reports an 89.6 percent survival rate in the first year of activity. This rate is higher than those found in previous studies. For instance, the U.S. Small Business Administration

\footnotetext{
${ }^{8}$ A. Robb et al. "An overview of the Kauffman Firm Survey”, results from the 2004-2007 data”, 2009.

${ }^{9}$ From A. Robb et al. "An overview of the Kauffman Firm Survey", results from the 2004-2007 data", 2009.

${ }^{10}$ This number rounds to 0.0 . Actual number is 0.04 .
} 
found the survival rate of single establishment firms founded in 1997 was only 75 percent in the first year. The $\mathrm{CBO}$ has found rates similar to the U.S. Small Business Administration for different cohorts of single establishment firms (Shane, 2008). The KFS could be registering higher rates for a simple reason: firms created in the beginning of 2004 and closing shortly after may have been omitted from the sample due to the screening method. Therefore, a firm that would have closed before the baseline survey was issued in 2005 could not be part of the sample ${ }^{11}$.

\subsection{Variable Description and Model Specification}

- $\quad$ The variables

The KFS reports a wide range of information regarding the birth and evolution of establishments in the sample. I concentrate on a small part of the firms' descriptive and financial variables. I also took into consideration the industry in which the firms operate because the environment of operation could affect survival rates (Huynh et al. 2008, Thompson 2005, Mata and Portugal 1994.) The variable describing survival is the dependant variable and takes the form of a dummy equal to 1 if the firm is active (survived), and equal to 0 if inactive (out of business) respectively during 2004, 2005, 2006, 2007.

Only firms created in 2004 and that survived the first year are part of the sample. As previously stated, a firm is considered to be out of business if it was sold to another business, merged with another business, has temporarily stopped operation (those observations were dropped) or just closed. To correct for non-response, I added the condition that a firm needed to be active in the previous year as well. Thus, survival in a current period is equal to 1 only if survival in the previous period is also equal to 1 and the business has not been declared to be out of business in the current period.

\footnotetext{
${ }^{11}$ Hall (1987) suggests that the sample bias created by the earlier death probability of younger firms is not a problem in her study of growth.
} 
I created three models. The first two models (M1 and M2) control for firm specific variables, with M2 adding leverage dummies to M1. M3 completes the series, adding an industry specific variable. I use the total number of employees on the firm's payroll (part time and full time) to proxy for the size of the firm. Most reasonable measures of size are positive functions of number of employees. The total value of assets and revenues could be good proxies for size but I believe that the number of employees is a better proxy. The reason is straightforward. The value of assets recorded in the KFS is most likely the book value, and therefore, has depreciation accounted for. Thus, although the firm can remain the same size from one year to the next, its recorded asset value will decrease. Moreover, firm's asset value described by the survey is classified in range variables. I could not use sales as a measure of size for the same reason. Thus the proxy for size is the first control variable on the right hand side (RHS) of M1. The total number of employees variable does not include the number of owner-operators. Regressions were run adding the number of owner-operators to the total number of employees and results were found to be similar ${ }^{12}$.

The survey reports the years of experience each owner has in the industry previous to the creation of the firm, giving me the second control variable on the RHS of M1- owners' previous industry experience proxies for quality of the firm. The intuition is that the more the owners have experience in the related industry prior to starting the firm, the higher the probability for it to be of a higher quality. Thompson (2005) studies the effects of previous years of experience in the industry in which the firm competes and finds it to be highly significant and important. I adopt the same approach.

I constructed the experience of the firm by calculating the mean experience brought in by each owner. The survey has an upper bound for years of experience equal to 40 years. Whether

\footnotetext{
${ }^{12}$ See Appendix 1.1 for results of first year regression on current conditions and last year regression on initial conditions using M3.
} 
the corresponding owner has 41 or more years of experience, he/she is registered as having $40+$ years of experience bringing me to censor the years of experience variable from above, and lock it to a maximum of 40. Assuming decreasing returns to experience, censoring from above should have little or no consequence. The latter assumption means that the marginal product of human capital is assumed to be decreasing. The argument could be made in which mean owners' relevant experience is not the best measure of the firm's experience. An average weighted according to the time put in the company by each owner would be a better measure. The more an owner works in the company, the higher the weight of his experience. Unfortunately, this method is impossible to apply given the data. The possibility of decreasing returns to experience is allowed for by including the square of the relevant experience.

Following the literature ${ }^{13}$, each firm in each period had their leverage calculated as a debt to value ratio ${ }^{14}$ defined as debt over assets and both values are reported by the survey. The KFS describes "total debts" to be the sum of the total debt owed by the owners ${ }^{15}$ and in the business' name. ${ }^{16}$ "Total assets" is the sum of all assets held by the firm. The dataset reports range variables for "total debt" and "total assets." 17 Operations not being possible on range variables, I use the ranges' midpoints as point of reference (I did not have access to the ranges' means and medians). The use of the median technique has been exploited in previous research ${ }^{18}$ including some

\footnotetext{
${ }^{13}$ See Cooley and Quadrini (2001) and Huynh et al. (2008).

${ }^{14}$ Debt to value $=\operatorname{debt} /($ debt + equity $)=\operatorname{debt} /$ assets and debt $=$ assets - equity.

${ }^{15}$ Debt taken by owner $=$ personal credit cards balance, personal loans taken from bank or family members or any other creditor, business credit cards for which the owner is responsible.

${ }^{16}$ Debt taken under business name $=$ credit cards balance established for the business, bank loans for the business, credit line of business, any other kind of loans taken under the business name (such as family, government, employees, other businesses).

${ }^{17}$ The survey classifies financial information under range variables.

${ }^{18}$ Kennickell (1997) suggests that range variables reported in the Survey of Consumer Finances is a limitation to research and thus suggests in Kennickell (1998) to use the midpoints of the respective ranges.
} 
working papers using the $\mathrm{KFS}^{19}$ and is accepted as an admissible replacement for real values. Asset values are book values and therefore are subject to depreciation.

A firm's calculated leverage is classified into dummy variables (five dummies were created). A leverage dummy equal to 0 at a given period means that the firm has not reported any debt and therefore the firm is financed entirely by equity (because of collinearity, this dummy was omitted from the regression). A leverage higher than 0 and lower than 1 in a given period means that the firm reported some existing debts of an amount smaller than its assets value and some positive equity was reported by the firm. A company that finances its assets completely with debt in a given time shows a leverage equal to 1 . A leverage equal to 1 means that the company has no equity or no equity left. An overleveraged firm has a leverage greater than 1 and has negative equity. The assets value is worth less than the debt owed by the firm. It could also be an indication that the firm has used some of the debt to pay for services or other aspects of business not describable as assets. I expect to see a negative value on this leverage. An infinite leverage $\mathrm{e}^{20}$ is the worst situation for a firm and could be thought of as a firm that borrowed money but has no assets to justify the debt. The firm spent the entire amount of the debt on expenses without accumulating any form of assets (e.g., locals, stock, machinery etc). I expect the coefficient attributed to this variable to be the most negative in the regressions. A firm with infinite leverage only has negative equity.

\footnotetext{
${ }^{19}$ The working paper by Braymen and Neymotin entitled "Immigrant enclaves and the success of entrepreneurial ventures" (december 2, 2009) assigned midpoints to the range variables whenever the respondent was asked to choose a range in the KFS. Robb and Coleman's working paper entitled "The impact of financial capital on business performance: a comparison of women- and men-owned firms" (may $7,2009)$ uses a similar approach.

${ }^{20}$ Although a division by 0 is algebraically undefined, the reader must consider that the assets' value is never really 0 . The value of assets is more likely to tend to 0 so the limit on the ratio goes to infinity.
} 
Table 1.4

Percentage in Two-digit Industries with Fewer than 20 Employees in 2004

\begin{tabular}{|lc|}
\hline \multicolumn{1}{|c|}{ Industry description } & $\begin{array}{c}\text { Firms } \\
\text { with } \\
\text { number } \\
\text { of } \\
\text { employees } \\
\text { below 20 }\end{array}$ \\
Forestry, fishing, hunting, and agriculture & $93 \%$ \\
support & \\
Mining & $82 \%$ \\
Utilities & $71 \%$ \\
Construction & $91 \%$ \\
Manufacturing & $69 \%$ \\
Wholesale trade & $86 \%$ \\
Retail trade & $86 \%$ \\
Transportation and warehousing & $83 \%$ \\
Information & $80 \%$ \\
Finance and insurance & $90 \%$ \\
Real estate and rental and leasing & $95 \%$ \\
Professional, scientific, and technical & $92 \%$ \\
services & \\
Management of companies and enterprises & $66 \%$ \\
Administrative and support and waste & $83 \%$ \\
management and Rremediation services & $76 \%$ \\
Educational services & $85 \%$ \\
Health care and social assistance & $84 \%$ \\
Arts, entertainment, and recreation & $72 \%$ \\
Accommodation and food services & $93 \%$ \\
Other services (except public & \\
administration) & 9 \\
\hline & \\
\hline
\end{tabular}

Note: The percentages represent how many firms employing the number of employees described by the scale variable can be found in the industry as of 2004 .

The scale variable represents the percentage of firms in the observation's two-digit industry that employs fewer than 20 employees (see Table 1.4). Åstebro and Bernhardt (2003), use two variables for 1 to 19 employees and 1 to 49 employees, the first variable being a subset of 
the second. Regressions were run using Åstebro and Bernhardt and adding their variables do not add explanatory power to the study (The results can be found in Appendix 1.2).

\section{- Model specification}

The dependent variable of interest (survival in a given period) is a dichotomous qualitative variable with outcomes survive $=1$ and exit $=0$. Therefore, a binary response regression model is needed in order to quantify the probability of survival. This study will use probit. As stated in the previous section, there are three model specifications. Each specification was run for survival in 2005, 2006 and 2007.

It is perhaps unusual to run separate regressions in order to capture the evolution of each variable over time and their influence on survival from one year to the next. Researchers usually use weighted regression models over many years (Geroski et al. 2010, Huynhh et al. 2008). Hazard models seem to be the most used tool of analysis although Mata and Portugal (1994) found similar results no matter the regressions (Weibull, ordered probit, ordered logit, Cox proportional hazard) using different model specifications, different assumptions of distribution and different sample definition. Hence probit should be just as effective and it has the advantage to be an easier model. The disadvantage of running separate probit regressions is that time effects cannot be controlled for. However, using the KFS, I only have access to one cohort of firms created in 2004. Thus, no age variable could be used in the regression and I could not test directly the age theory (this means that there is no age effect because firms are all the same age). Moreover, Thompson (2005) shows that the age effect on exit is eliminated when quality proxies are added to the regression. Thompson (2005) uses prior experience to proxy for quality and concludes that the age effect found on survival could be explained by selection bias. Hence, a separate probit should be a good tool of analysis.

Assuming that the total number of employees is a good proxy for size and considering that it has been used as such in many papers (Geroski et al. 2010, Mata and Portugal 1994), I 
introduce it as a control variable in the base regression model. The M1 model is a simple model that controls only for size and quality, using total number of employees and the owners' mean industry experience as respective proxies. Decreasing returns to experience were also allowed for by using the square of the mean relevant experience variable.

Some studies have been conducted on the determinants of growth over time, while others have focused on the initial starting size (Dunne et al. 1989, Mata and Portugal 1994, Haveman 1995, Audretsh and Mahmood 1994, Geroski et al. 2010, Sharma and Kesner 1996, Mitchell 1994). A simple reason for the higher failure rate of smaller firms is that larger firms have the option to downsize when needed (cut expenses). Moreover, in difficult times, larger firms can withdraw from dying markets and refocus on the ones still alive. The withdrawing choice is more difficult for smaller firms because of the smaller scope of their operations. Others ${ }^{21}$ have suggested that larger firms are less susceptible to financial constraints and therefore have access to funds during unexpected difficult times or even to finance projects. An interesting alternative explanation deals with the costs of production. There are lower costs associated with producing at a larger scale (Lucas 1978). These lower costs could happen for two reasons. First, a larger size allows the firm to operate further down the cost curve. The second reason is that fewer financial constraints allow the firm to operate at higher scale. Moreover, the bigger a firm is, the closer to the minimum efficient scale (MES) of production it is and the lower its costs of production.

Geroski et al. (2010) also report a non-instantaneous increase in survival prospects as a firm's size increases. This latter relationship between survival and size is partly consistent with Jovanovic (1982), in which firms adjust their size instantaneously (by learning about their efficiency as time goes by) according to past performance, and only current size matters in predicting survivability. The KFS allows me to see if size is indeed an increasing factor of

\footnotetext{
${ }^{21}$ Fazzari et al. (1988) was a pioneer paper that asked the cash flow effect on investment question. Zingales 1998, like Fazzari et al. (1998), study the effect of capital market imperfections on survival. They find that highly leveraged firms are less likely to survive.
} 
survivability $^{22}$. Regarding the founding conditions, entering larger sends a positive signal and relaxes the liquidity constraints proposed by Evans and Jovanovic (1989). Thus, I expect positive and significant coefficients on the number of employees in both current and founding conditions regressions.

Pre-entry relevant experience has also been shown to be an important predictor of survival. After showing pre-entry relevant experience to be a good proxy for quality, Thompson (2005) affirms that relevant experience does indeed have persistent effects on survival and moreover, the effects do not decay over a long period of time. Geroski et al. (2010) indirectly test the hypothesis (following previous research like Wernerfelt 1984, Barney 1991 and Youndt et al. 1996) that human capital is the factor that provides the hedge because it cannot be replicated by the competitors. Geroski et al. (2010) use education as a proxy for human capital, and find that education reduces the hazard of exit. Lucas (1978) shows that having better quality human capital allows a firm to lower its cost at any given level of production, thus seeking to produce at a larger scale.

The link between financial variables and firm dynamics has just recently started to attract the attention of researchers. Lack of financial data was the main reason empirical studies proved to be a challenge. Firms are reluctant to disclose information regarding their financial structure. Whenever the financial data is available, sampled firms are already too old and have already overcome the first stages of growth. We know that younger firms grow faster than older, and that survival is positively related to age (Evans 1987, Dunne et al. 1989). Thus, if the sample is aged, we can assume that exit rates will be too low to conduct interesting research. This is commonly referred to as a sample bias problem ${ }^{23}$.

\footnotetext{
${ }^{22}$ I do find an increase in the coefficient on size for the second year. I also find that the coefficient on size is greater on current state than the coefficient on initial state.

${ }^{23}$ See Hall (1987).
} 
The model M2 adds five financial leverage dummies to the base model. Huynh et al. (2008) used quintiles dummies and found that the nonlinear model fitted the data better than the linear one. Thus, adding dummies to the regression (different slopes) helps me model the nonlinear property of leverage on survival.

Cases were found with reported assets value equal to 0 . These observations are associated with an infinite ratio representing the worst case of financial state for the firm. No debt was reported in some cases and, as previously stated, the corresponding dummy was omitted from the regression (for collinearity purposes).

There is empirical evidence reporting that higher debt decreases the probability of survival. Huynh et al. (2009) found that once they control for size and productivity, firms with high level of leverage (debt to value ratio measured debt over assets) face an increasing failure risk with an increase in leverage. Alternatively, firms with low to moderate leverage have higher survival chances. Huynh et al. (2008) look at the introduction of the initial debt to value ratio into the firm dynamics and found it to be economically and statistically significant. They find that the higher the debt to asset ratio is at birth, the lower the life expectancy of the firm. However, it is to be noted that it is the increase in the debt to asset ratio that is dangerous and therefore it could either be an increase in debt or a decrease in asset value (book value depreciation maybe).Myers (1977) had already suggested that higher level of debt may limit a firm's real value. Access to debt can influence survival trough both a positive and a negative relation. On the one hand, the more a firm has access to debt, the more it can finance its activities and therefore survive. On the other hand, the more debt a firm owes, the higher the temptation to walk away from the debt when found in harsh economic conditions. The debt to value ratio allows me to measure the financial obligations of a firm for each value unit of assets (book value) it has. Huynh et al. (2009) control simultaneously for size, age and leverage and find that initial asset value had a positive effect on growth, providing evidence to the "deep pocket theory" suggested by Zingales 
(1998). The higher the asset stock at creation, the more positive the message sent to debt institutions and the more the firm has access to debt to finance its growth.

Huynh, Petronia and Voia research was conducted on the startup financial conditions and on a sample of manufacturing firms. Actually, most of the papers I have come across testing for leverage effects (financial conditions) onto survival or growth were done on a sample of manufacturing firms. Those results should be tested on other industries due to the fact that the manufacturing industry is highly capital-intensive. The KFS also provides me with a higher range of smaller industries. The interesting question would be whether or not increasing debt in the firm youth is a predictor of exit, while controlling for industry scale? This question will be addressed in the third model.

The literature on firm dynamics emphasizes the importance of industry specific variables along firm specific variables. Audretsch (1991) looks at industrial variables effects on survival and found that survival rates do vary across industries; a finding that previous empirical research had not reported. Audretsch indicates that industry's specific technical conditions as well as industry's demand are important predictors of survival. Audretsch and Mahmood (1994), expends Audretsch (1991) by adding macro variables and firm level variables such as size and ownership. Audretsch and Mahmood (1994) shows that size, when added to industry scale variables, can influence survival positively and thus reduce the negative effects of higher scale on survival. The literature ${ }^{24}$ indicates that the bigger a firm is, the closer it will be to the MES and therefore operate at a lower point on the cost curve, reducing cost and increasing profit, thus increasing chances of survival.

The third model adds a scale variable defined as the percentage of firms found in the two digits NAICS industry code in 2004 (represents date of entry for the sample) with fewer than 20 employees. Åstebro and Bernhadt (2003) find entering a small scale industry is a positive

\footnotetext{
${ }^{24}$ Geroski et al. (2010), Mata and Portugal (1994).
} 
predictor of survival while entering a high scale industry is a negative predictor of survival. Åstebro and Bernhadt run probit regressions and found that initial entrance into a higher scale industry is a hazard for survival. The coefficient attributed to their variable representing a scale of fewer than 50 employees was negative and twice as big in magnitude as compared to the coefficient on the variable representing a scale of fewer than 20 employees (positive sign). The research and results provided by Åstebro and Bernhadt are only giving information on the founding conditions. I am not aware of a study that joins a leverage variable to an industry scale variable. I trust that M3 will help understand whether the impact of debt is increased or decreased when industry scale is controlled for.

Audretsch and Mahmood (1994) have studied the effect of concentration in an industry on survival and they have found it to be significantly negative. Geroski et al. (2010) suggest the more concentrated the industry at time of entry, the less the chances of exit, with the effects disappearing post entry. Geroski et al. (2010)'s finding on industry concentration supports the trial by fire hypothesis and suggests that the fittest survive in a highly concentrated market, hence in reality high concentration at entry increases probability of exit for the unfit firms. Once a firm enters a highly concentrated market and survives, it is more likely it will prosper in the future.

The scale variable proxies for the scale of the industry in which the observation is operating. When the scale variable is not in the model, the number of employees accounts for its effects via the MES theory. A firm's large size represents the will to reach a higher scale of operation bringing the coefficient on size down. Once the scale variable is added, correcting for its effect on size, the coefficient on size should increase. Assuming Geroski et al. (2010) are right; I should observe insignificant results on the years following entrance ${ }^{25}$. Moreover, assuming that low scale industries are associated with high competitive forces - and conversely that high scale

${ }^{25}$ Concentration was found insignificant in previous studies like Mata and Portugal (1994) and Huyghebaert and Van de Gucht (2004). 
industries are associated with strong negative forces at entrance due to incumbents' market control — entry in a low scale industry should decrease ${ }^{26}$ probability of survival.

\subsection{Empirical Results}

- Effects of current year conditions on survival in the following period

Results for this section are presented in Tables 1.5, 1.6 and 1.7. The model M1 returns a positive, significant and persistent effect of size on survival. The literature has reported that the bigger a firm is, the more it can access external debt ${ }^{27}$ to finance growth and survive (Dunne et al. 1989, Thompson 2005). The coefficients found for each year on size suggest that size contributes consistently to the probability of survival next year.

The coefficient on the total number of employees goes up once the industry scale is accounted for in 2005 and 2006. An increase on the total number of employees' coefficient is expected because we know that total number of employees accounts for at least two effects in M1 and M2. First, how successful the firm is (the more employees the firm has, the better it is doing) - this effect is positive. Second, how much employees are needed in the industry (the more employees a firm has the higher the probability it is in a higher scale industry and therefore the lower the probability of survival) - this effect is negative. By adding the industry scale variable to M2, I am controlling for the number of employees needed in the industry, which was previously bringing the coefficients on size down. Therefore the coefficient on the number of employees has to go up in the third model as compared to M1 and M2.

The mean experience in the industry, which is a proxy for quality, also proves to be an interesting predictor of survival. The coefficient is always really significant and positive. The coefficient on experience does not fluctuate much across models, suggesting that its effects on survival are somehow independent from other predictors. However, we do notice that the

\footnotetext{
${ }^{26}$ Hannan and Carrol (1992) asserts that competition increases mortality.

${ }^{27}$ See Pointevin (1989), Zingales (1998).
} 
coefficients go up from one year to the next, suggesting that experience becomes increasingly important for survival. As previously assumed, the quadratic variable for experience reports a consistently small negative coefficient indicating that relevant experience have a slight marginal decreasing return on survival.

Table 1.5

Regressions of Survival in 2005 using 2004 Control Variables

\begin{tabular}{|c|c|c|c|}
\hline Models & $M 1$ & M2 & $M 3$ \\
\hline Control Variables in 2004 & $\begin{array}{c}\text { Probability } \\
\text { of survival } \\
\text { in year } \\
2005\end{array}$ & $\begin{array}{c}\text { Probability } \\
\text { of survival } \\
\text { in year } \\
2005\end{array}$ & $\begin{array}{c}\text { Probability } \\
\text { of survival } \\
\text { in year } \\
2005\end{array}$ \\
\hline Total number of employees & $\begin{array}{c}0.026 \\
(2.39)^{* *}\end{array}$ & $\begin{array}{c}0.023 \\
(2.10)^{* *}\end{array}$ & $\begin{array}{c}0.028 \\
(2.50)^{* *}\end{array}$ \\
\hline Relevance of experience & $\begin{array}{c}0.033 \\
(3.56)^{* * *}\end{array}$ & $\begin{array}{c}0.031 \\
(3.27)^{* * *}\end{array}$ & $\begin{array}{c}0.029 \\
(3.06)^{* * *}\end{array}$ \\
\hline $\begin{array}{l}\text { Quadratic of the relevance } \\
\text { of experience }\end{array}$ & $\begin{array}{c}-0.001 \\
(2.88)^{* * *}\end{array}$ & $\begin{array}{c}-0.001 \\
(2.60)^{* * *}\end{array}$ & $\begin{array}{c}-0.001 \\
(2.48)^{* *}\end{array}$ \\
\hline Leverage between 0 and 1 & - & $\begin{array}{c}0.169 \\
(1.96)^{*}\end{array}$ & $\begin{array}{c}0.171 \\
(1.98)^{* *}\end{array}$ \\
\hline Leverage equal to 1 & - & $\begin{array}{l}0.029 \\
(0.31)\end{array}$ & $\begin{array}{l}0.035 \\
(0.36)\end{array}$ \\
\hline Leverage greater than 1 & - & $\begin{array}{l}-0.167 \\
(1.64)\end{array}$ & $\begin{array}{l}-0.165 \\
(1.62)\end{array}$ \\
\hline Leverage is infinite & - & $\begin{array}{c}-0.203 \\
(2.14)^{* *}\end{array}$ & $\begin{array}{c}-0.2 \\
(2.10)^{* *}\end{array}$ \\
\hline $\begin{array}{l}\text { Portion in the industry with } \\
\text { fewer than } 20 \text { employees }\end{array}$ & - & - & $\begin{array}{c}1.847 \\
(2.85)^{* * *}\end{array}$ \\
\hline Constant & $\begin{array}{c}1.379 \\
(22.97)^{* * *}\end{array}$ & $\begin{array}{c}1.399 \\
(18.67)^{* * *}\end{array}$ & $\begin{array}{l}-0.21 \\
(0.37)\end{array}$ \\
\hline Observations & 4582 & 4582 & 4582 \\
\hline
\end{tabular}

Absolute value of $\mathrm{z}$ statistics in parentheses.

$*$ significant at $10 \% ; * *$ significant at $5 \% ; * * *$ significant at $1 \%$

Adding leverage dummies to the regression consistently bring the coefficients on size down. Thus, size must be accounting for a portion of the contribution of leverage on survival, which confirms the important role of financial structure on survival. 
As previously stated, some studies ${ }^{28}$ found that the hazard of exit was augmented by debt and hence debt had a negative effect on survival. The M2 model output reaffirms the results found in Huynh et al. (2008) and (2009). The coefficients associated to leverage with more debt than asset are negative and the larger the difference, the more negative the coefficients become (the coefficients on infinite leverage are more negative than the coefficients on leverage greater than 1). Therefore more debt increases the incentive to walk away and close the company as opposed to finance growth (the second hypothesis is stronger than the first one).

During the first year of activity, survival probability is increased when assets are financed with debt and equity. A debt amount below the assets value means that the owners have some positive equity in the company and therefore have an incentive to put more efforts into running the company, which in turn increases the probability of survival. In this scenario the positive effect dominates. The incentive to walk away from the debt is low because of the positive equity. The coefficient on leverage between 0 and 1 is only significant in the first year. The negative effects associated with the coefficients on infinite leverage are significant for 2005 and 2006 and increase from one year to the next. The increase suggests that if the firm has not financed some assets with the debt it owes by the second year, its exit probability is increased, confirming the second hypothesis regarding the effects of debt (walking away from it). Leverage significance disappears as the firms enter their third year (I explain below that only initial effects are still significant by then). Current leverage becomes an insignificant predictor of survival as the firm becomes older. Checking the validity of both theories as the cohort ages will be possible as more data waves are released. Note that when running linear regressions with size as the dependant variable, I find that the more balanced the leverage is (leverage $=1$ ), the larger the firm (see Appendix 1.3).

${ }^{28}$ Cooley and Quadrini (2001), Huynh et al. (2008) and (2009), Huynh et al. (2009). 
Table 1.6

Regressions of Survival in 2006 using 2005 Control Variables

\begin{tabular}{|c|c|c|c|}
\hline Models & M1 & M2 & M3 \\
\hline Control Variables in 2005 & $\begin{array}{c}\text { Probability } \\
\text { of survival } \\
\text { in year } \\
2006\end{array}$ & $\begin{array}{c}\text { Probability } \\
\text { of survival } \\
\text { in year } \\
2006\end{array}$ & $\begin{array}{c}\text { Probability } \\
\text { of survival } \\
\text { in year } \\
2006\end{array}$ \\
\hline \multirow[t]{2}{*}{ Total number of employees } & 0.029 & 0.027 & 0.028 \\
\hline & $(3.20)^{* * *}$ & $(2.94) * * *$ & $(3.02)^{* * *}$ \\
\hline \multirow[t]{2}{*}{ Relevance of experience } & 0.034 & 0.034 & 0.033 \\
\hline & $(3.43)^{* * *}$ & $(3.35)^{* * *}$ & $(3.27)^{* * *}$ \\
\hline Quadratic of the relevance & -0.001 & -0.001 & -0.001 \\
\hline of experience & $(2.65)^{* * *}$ & $(2.58)^{* * *}$ & $(2.52)^{* *}$ \\
\hline \multirow[t]{2}{*}{ Leverage between 0 and 1} & - & 0.097 & 0.099 \\
\hline & & $(1.19)$ & $(1.22)$ \\
\hline \multirow[t]{2}{*}{ Leverage equal to 1} & - & 0.066 & 0.069 \\
\hline & & $(0.61)$ & $(0.64)$ \\
\hline \multirow[t]{2}{*}{ Leverage greater than 1} & - & -0.071 & -0.069 \\
\hline & & $(0.59)$ & $(0.57)$ \\
\hline \multirow[t]{2}{*}{ Leverage is infinite } & - & -0.264 & -0.264 \\
\hline & & $(2.22)^{* *}$ & $(2.22)^{* *}$ \\
\hline \multirow{2}{*}{$\begin{array}{l}\text { Portion in the industry with } \\
\text { fewer than } 20 \text { employees }\end{array}$} & - & - & 0.616 \\
\hline & & & $(0.82)$ \\
\hline \multirow[t]{2}{*}{ Constant } & 1.233 & 1.234 & 0.694 \\
\hline & $(19.16)^{* * *}$ & $(16.35)^{* * *}$ & $(1.05)$ \\
\hline Observations & 3664 & 3664 & 3664 \\
\hline
\end{tabular}

Absolute value of $\mathrm{z}$ statistics in parentheses.

$*$ significant at $10 \% ; * *$ significant at $5 \% ; * * *$ significant at $1 \%$

The M3 model shows that entering a smaller scale industry increases the probability of survival. Assuming that lower scale industries are less concentrated because of lower barriers of entry, this finding contradicts the common belief ${ }^{29}$ that competition increases exit rates. However, these negative effects are active as the density within the industry is increasing and the market becomes crowded with firms. Hence, it could be that the markets are not crowded yet as the firms enter their respective low scale industry. Not surprisingly, the industry scale variable is only significant the first year, confirming Geroski et al. (2010) that found that the effects of industry

\footnotetext{
${ }^{29}$ See Hannan and Carrol (1992).
} 
concentration at entrance disappear after the first year. Once a firm enters an industry, this decision cannot be reversed. The effects are therefore only visible on the first year and in the founding conditions. Thus it is the industry entrance choice that is significant and the current activity in a specific industry. According to the "trial by fire" hypothesis, a firm entering a highly concentrated market and surviving the first year has more chances to survive and prosper in the future. Only the firms with the financial capacities (deep pocket theory) should adventure themselves in a higher scale industry for the prospects of higher potential price-cost margins. However, the higher scale industry (percentage of firms in the two digit SIC code industry with more than 20 employees) is associated with a negative effect on survival, which raises the question: why would a firm with low financial capacities choose to enter a high scale industry? I suggest a possible intuitive explanation. A higher scale industry requires heavy investments and higher sunk costs as compared to a smaller scale industry. However, the border line is not perceivable (in my definition the marginal employee puts the firm into the higher scale) and firms enter a higher scale industry because of expectations of higher revenues (higher price-cost margin). Pre-entrance, the firm has expectations on costs and revenues. However, those expectations are prone to noise. Once a firm enters, the noise is reduced as time passes and the firm learns about the financial burden associated with higher cost forced by the scale and lower revenues due to the incumbents' market power. When the noise is eliminated, and the firm realizes the true requirements associated with operating in a higher scale industry, it decides to continue its operation(s) or exit. Firms commit the mistake of entering a higher scale industry because they perceive a "mid-scale industry" between the smaller and higher scale. This "midscale" is believed easier to reach than the higher scale, and is expected to provide the firm with higher revenues. Hence the firm commits the mistake to enter and exits later. 
Table 1.7

Regressions of Survival in 2007 using 2006 Control Variables

\begin{tabular}{|c|c|c|c|}
\hline Models & M1 & M2 & M3 \\
\hline Control Variables in 2006 & $\begin{array}{c}\text { Probability } \\
\text { of survival } \\
\text { in year } \\
2007\end{array}$ & $\begin{array}{c}\text { Probability } \\
\text { of survival } \\
\text { in year } \\
2007\end{array}$ & $\begin{array}{c}\text { Probability } \\
\text { of survival } \\
\text { in year } \\
2007\end{array}$ \\
\hline Total number of employees & $\begin{array}{l}0.029 \\
(3.39)^{* * *}\end{array}$ & $\begin{array}{l}0.026 \\
(3.08)^{* * *}\end{array}$ & $\begin{array}{l}0.026 \\
(3.01)^{* * *}\end{array}$ \\
\hline Relevance of experience & $\begin{array}{l}0.037 \\
(3.60)^{* * *}\end{array}$ & $\begin{array}{l}0.036 \\
(3.52)^{* * *}\end{array}$ & $\begin{array}{l}0.036 \\
(3.52)^{* * *}\end{array}$ \\
\hline $\begin{array}{l}\text { Quadratic of the relevance } \\
\text { of experience }\end{array}$ & $\begin{array}{l}-0.001 \\
(2.86)^{* * *}\end{array}$ & $\begin{array}{l}-0.001 \\
(2.79)^{* * *}\end{array}$ & $\begin{array}{l}-0.001 \\
(2.80)^{* * *}\end{array}$ \\
\hline Leverage between 0 and 1 & - & $\begin{array}{l}0.061 \\
(0.75)\end{array}$ & $\begin{array}{l}0.06 \\
(0.74)\end{array}$ \\
\hline Leverage equal to 1 & - & $\begin{array}{l}0.097 \\
(0.88)\end{array}$ & $\begin{array}{l}0.097 \\
(0.88)\end{array}$ \\
\hline Leverage greater than 1 & - & $\begin{array}{l}-0.114 \\
(0.94)\end{array}$ & $\begin{array}{l}-0.114 \\
(0.94)\end{array}$ \\
\hline Leverage is infinite & - & $\begin{array}{l}-0.165 \\
(1.3)\end{array}$ & $\begin{array}{l}-0.165 \\
(1.3)\end{array}$ \\
\hline $\begin{array}{l}\text { Portion in the industry with } \\
\text { fewer than } 20 \text { employees }\end{array}$ & - & - & $\begin{array}{l}-0.181 \\
(0.24)\end{array}$ \\
\hline Constant & $\begin{array}{l}1.093 \\
(16.24)^{* * *}\end{array}$ & $\begin{array}{l}1.095 \\
(14.06)^{* * *}\end{array}$ & $\begin{array}{l}1.254 \\
(1.92)^{*}\end{array}$ \\
\hline Observations & 3092 & 3092 & 3092 \\
\hline
\end{tabular}

Absolute value of $\mathrm{z}$ statistics in parentheses.

* significant at $10 \% ; * *$ significant at $5 \% ; * * *$ significant at $1 \%$

- Effects of founding conditions on survival in the following periods

As previously suggested by Mata et al. (1995) Tables 1.8 and 1.9 show that initial size has persisting positive effects on survival later in the life of the firm. Initial size carries minimal decrease in coefficients in the years following birth. I find that the coefficients on initial size are below those found in Tables 1.5, 1.6 and 1.7, hinting to size in the current year being more important for survival than founding size, echoing the results found in Mata et al. (1995). 
Table 1.8

Regressions of Survival in 2006 using 2004 Control Variables

\begin{tabular}{|c|c|c|c|}
\hline Models & $M 1$ & $M 2$ & M3 \\
\hline Control Variables in 2004 & $\begin{array}{c}\text { Probability } \\
\text { of survival } \\
\text { in year } \\
2006\end{array}$ & $\begin{array}{c}\text { Probability } \\
\text { of survival } \\
\text { in year } \\
2006\end{array}$ & $\begin{array}{c}\text { Probability } \\
\text { of survival } \\
\text { in year } \\
2006\end{array}$ \\
\hline \multirow[t]{2}{*}{ Total number of employees } & 0.02 & 0.017 & 0.02 \\
\hline & $(2.72)^{* * *}$ & $(2.21)^{* *}$ & $(2.65)^{* * *}$ \\
\hline \multirow[t]{2}{*}{ Relevance of experience } & 0.033 & 0.032 & 0.031 \\
\hline & $(4.48)^{* * *}$ & $(4.29)^{* * *}$ & $(4.04)^{* * *}$ \\
\hline \multirow{2}{*}{$\begin{array}{l}\text { Quadratic of the relevance } \\
\text { of experience }\end{array}$} & -0.001 & -0.001 & -0.001 \\
\hline & $(3.43)^{* * *}$ & $(3.26)^{* * *}$ & $(3.09)^{* * *}$ \\
\hline \multirow[t]{2}{*}{ Leverage between 0 and 1} & - & 0.036 & 0.039 \\
\hline & & $(0.55)$ & $(0.6)$ \\
\hline \multirow[t]{2}{*}{ Leverage equal to 1} & - & 0.094 & 0.101 \\
\hline & & $(1.22)$ & $(1.31)$ \\
\hline \multirow[t]{2}{*}{ Leverage greater than 1} & - & -0.179 & -0.175 \\
\hline & & $(2.16)^{* *}$ & $(2.11)^{* *}$ \\
\hline \multirow[t]{2}{*}{ Leverage is infinite } & - & -0.249 & -0.245 \\
\hline & & $(3.23)^{* * *}$ & $(3.17)^{* * *}$ \\
\hline \multirow{2}{*}{$\begin{array}{l}\text { Portion in the industry with } \\
\text { fewer than } 20 \text { employees }\end{array}$} & - & - & 1.668 \\
\hline & & & $(3.21)^{* * *}$ \\
\hline \multirow[t]{2}{*}{ Constant } & 0.948 & 0.988 & -0.466 \\
\hline & $(19.64)^{* * *}$ & $(16.43)^{* * *}$ & $(1.02)$ \\
\hline Observations & 4582 & 4582 & 4582 \\
\hline
\end{tabular}

Absolute value of $\mathrm{z}$ statistics in parentheses.

$*$ significant at $10 \% ; * *$ significant at $5 \% ; * * *$ significant at $1 \%$

Experience has similar coefficients for current and founding conditions. Geroski et al. (2010) suggested that the most valuable experience is the founding experience but my results report a slightly larger coefficient on experience for current conditions. That said, coefficients on relevant experience are not statistically different in the 95 percent confidence interval. Hence, despite the non-negligible contribution made by initial experience, current experience remains an important contributor to survival. I believe that this is a result of the correlation between current 
experience and founding experience. Thinking of experience as a stock of human capital, it is increasing (the human capital stock is building upon the initial stock) as the firm ages.

The coefficients associated with founding leverage dummies are significant in the cases with negative equity (debt is greater than assets). Firms with initial leverage greater than 1 or with an infinite leverage saw their probability of survival greatly diminished. A firm that starts operation with negative equity sees its likelihood of exit soar. This is true in 2006 and 2007. The coefficients on infinite leverage are decreasing in magnitude from 2006 and 2007 while the coefficients for leverage greater than 1 are increasing. The loss in significance associated with the infinite leverage coefficient can be justified with the following intuition. An infinite leverage at foundation is most likely going to force an exit in the first years of activity and thus less firms in the cohort as subject to its effects. To summarize, having negative equity at start up diminishes greatly a firm's probability of survival during the first years of activity. The industry scale variable points to an interesting clue on the effects of industry scale on debt. It seems that entering a smaller scale industry reduces the negative effects brought by debt on survival. The coefficients associated with negative equity and infinite leverage are decreasing in magnitude once small industry scale is controlled for. This could be explained with the following intuition. The individuals entering a low scale industry most likely have to put their own assets as collateral (such as home). Therefore walking away from the debt is harder and efforts and time will be invested by owners, hence increasing the survival probability.

Entering a small industry scale at foundation is an important and significant predictor of survival. The choice of operating industry is made at the firm's entrance and thus the coefficients and foundation are positive and significant in both 2006 and 2007. Tables 1.8 and 1.9 also report that the positive effect associated with entering a lower scale industry is decreasing as the firm ages (from 1.668 in 2006 to 1.003 in 2007).This could be the result of an entrance into a low density industry that becomes more crowded as the firm ages consequently the positive effects 
disappear to give place to - maybe - negative effects in the future. More data waves would help estimate how long the effects associated with an industry entrance remain a significant predictor of survival.

Table 1.9

Regressions of Survival in 2007 using 2004 Control Variables

\begin{tabular}{|c|c|c|c|}
\hline Models & $M 1$ & $M 2$ & $M 3$ \\
\hline Control Variables in 2004 & $\begin{array}{l}\text { Probability } \\
\text { of Survival } \\
\text { in year } \\
2007\end{array}$ & $\begin{array}{c}\text { Probability } \\
\text { of Survival } \\
\text { in year } \\
2007\end{array}$ & $\begin{array}{c}\text { Probability } \\
\text { of Survival } \\
\text { in year } \\
2007\end{array}$ \\
\hline \multirow[t]{2}{*}{ Total number of employees } & 0.019 & 0.017 & 0.02 \\
\hline & $(3.07)^{* * *}$ & $(2.76)^{* * *}$ & $(3.07)^{* * *}$ \\
\hline \multirow[t]{2}{*}{ Relevance of experience } & 0.036 & 0.034 & 0.033 \\
\hline & $(5.48)^{* * *}$ & $(5.12)^{* * *}$ & $(4.96)^{* * *}$ \\
\hline \multirow{2}{*}{$\begin{array}{l}\text { Quadratic of the relevance } \\
\text { of experience }\end{array}$} & -0.001 & -0.001 & -0.001 \\
\hline & $(4.15)^{* * *}$ & $(3.88)^{* * *}$ & $(3.79)^{* * *}$ \\
\hline \multirow[t]{2}{*}{ Leverage between 0 and 1} & - & 0.025 & 0.025 \\
\hline & & $(0.43)$ & $(0.45)$ \\
\hline \multirow[t]{2}{*}{ Leverage equal to 1} & - & 0.01 & 0.013 \\
\hline & & $(0.15)$ & $(0.2)$ \\
\hline \multirow[t]{2}{*}{ Leverage greater than 1} & - & -0.265 & -0.262 \\
\hline & & $(3.60)^{* * *}$ & $(3.57)^{* * *}$ \\
\hline \multirow[t]{2}{*}{ Leverage is infinite } & - & -0.2 & -0.197 \\
\hline & & $(2.85)^{* * *}$ & $(2.80)^{* * *}$ \\
\hline \multirow{2}{*}{$\begin{array}{l}\text { Portion in the industry with } \\
\text { fewer than } 20 \text { employees }\end{array}$} & - & - & 1.003 \\
\hline & & & $(2.16)^{* *}$ \\
\hline \multirow[t]{2}{*}{ Constant } & 0.604 & 0.665 & -0.21 \\
\hline & $(13.99)^{* * *}$ & $(12.46)^{* * *}$ & $(0.52)$ \\
\hline Observations & 4582 & 4582 & 4582 \\
\hline
\end{tabular}

Absolute value of $\mathrm{z}$ statistics in parentheses.

$*$ significant at $10 \% ; * *$ significant at $5 \% ; * * *$ significant at $1 \%$

\subsection{Conclusion}

This paper is to be considered as an introductory study to firm dynamics using the Kauffman Firm Survey. My intention is to provide a starting point and a global perspectiveusing the KFS - on the effects of founding and current firm's conditions on its survival. Scholars 
have already covered a broad range of subjects regarding the factors prone to increase the probability of survival. Many theories followed by empirical evidence assert that size and relevant experience are positive predictors of a firm's survival in both current and founding conditions. However, other dimensions specific to a firm's financial and environmental conditions are more obscure. The effects of leverage and industry's concentration are less evident. The available data had always been lacking financial information on a broader range of industries which is why most financial research on firm dynamics was directed toward manufacturing and high-tech industries. Research has also claimed the non negligible and even important effects of founding conditions on survivability in the future periods. The release of the KFS allows me to conduct a more suitable study on the effects of leverage and industry scale in the current and founding conditions. I run three different probit models on survival using both current and founding conditions.

The results reaffirm the importance of size in both current and founding regressions with current size being more important than startup size. First, a bigger size in the current state allows the firm to be operating closer to the MES and hence be more efficient. Second, the bigger a firm is the more room it has to downgrade when needed. This last theoretical advantage is also true for the founding size. Moreover, bigger size at startup sends a positive signal to lenders.

I find that relevant experience is a significant positive predictor of survival and is prone to diminishing returns. Like Thompson (2005), the regressions report that the importance of relevant experience does not decay.

The probability of survival is decreasing with leverage and it seems that debt-when not justified by acquiring assets - is a negative contributor to survival. The more debt the company has at startup the more likely the exit with effects decaying as the company matures. When the firm has negative equity, the probability of exit is found to be greater in both current and founding conditions regressions. 
The effects of industry scale are significant only for industry entrance as opposed to yearly activity within the industry. The result that causes concern is the positive effects associated with entrance into a small scale industry. This goes against the generally accepted proposition that competition increases the probability of exit but can be justified by low density within the industry at time of entrance. Besides, Åstebro and Bernhardt (2003) find similar results. Moreover, the regressions results on M3 brings up a new proposition-entrance in a small scale industry reduces the negative effects of debt (more realistically of negative equity).

As more waves and data become available, more questions can be answered which opens the door to future research possibilities. For example, can we estimate the time frame before founding conditions' effects on survival become insignificant or what is the link between industry concentration and firms' survival? 


\section{REFERENCES}

Arabsheibani, G., de Meza, J., Maloney, J. \& Pearson, B., 2000. And a vision appeared unto them of a great profit: evidence of self-deception among the self-employed. Economics Letters, 67(1), pp.35-41.

Åstebro, T. \& Bernhardt, I., 2003. Start-up financing, owner characteristics, and survival. Journal of Economics and Business, 55(4), pp.303-319.

Audretsch, D.B., 1991. New-Firm Survival and the Technological Regime. The Review of Economics and Statistics, 73(3), pp.441-450.

Audretsch, D.B. \& Mahmood, T., 1994. The rate of hazard confronting new firms and plants in U.S. manufacturing. Review of Industrial Organization, 9(1), pp.41-56.

Barney, J., 1991. Firm Resources and Sustained Competitive Advantage. Journal of Management, 17(1), pp.99 -120.

Bernardo, A.E. \& Welch, I., 2001. On the evolution of overconfidence and entrepreneurs. Journal of Economics \& Management Strategy, 10(3), pp.301-330.

Braymen, C. \& Neymotin, F., 2009. Immigrant Enclaves and the Success of Entrepreneurial Ventures. Available at: http://ssrn.com/abstract $=1518929$.

Camerer, C. \& Lovallo, D., 1999. Overconfidence and excess entry: An experimental approach. The American Economic Review, 89(1), pp.306-318.

Carroll, G. R., Bigelow, L. S., Seidel, M. D. L. \& Tsai, L. B., 1996. The fates of de novo and de alio producers in the American automobile industry 1885-1981. Strategic Management Journal, 17(S1), pp.117-137.

Cooley, T.F. \& Quadrini, V., 2001. Financial markets and firm dynamics. American Economic Review, pp.1286-1310.

Dunne, T., Roberts, M.J. \& Samuelson, L., 1989a. Plant turnover and gross employment flows in the US manufacturing sector. Journal of Labor Economics, pp.48-71.

Dunne, T., Roberts, M.J. \& Samuelson, L., 1989b. The growth and failure of US manufacturing plants. The Quarterly Journal of Economics, 104(4), p.671-698.

Evans, D.S., 1987. The relationship between firm growth, size, and age: Estimates for 100 manufacturing industries. The Journal of industrial economics, pp.567-581.

Evans, D.S. \& Jovanovic, B., 1989. An estimated model of entrepreneurial choice under liquidity constraints. The Journal of Political Economy, pp.808-827.

Fazzari, S.M., Hubbard, G.R. \& Petersen., B.C., 1988. Financing Constraints and Corporate Investment. Brookings Papers on Economic Activity, 1, pp.141-195.

Geroski, P.A., Mata, J. \& Portugal, P., 2010. Founding conditions and the survival of new firms. Strategic Management Journal, 31(5), pp.510-529. 
Gibrat, R., 1931. Les inégalités économiques, applications: aux inégalités des richesses, à la concentration des entreprises, aux populations des villes, aux statistiques des familles, etc., d'une loi nouvelle, la loi de l'effet proportionnel. Paris: Librairie du Recueil Sirey.

Gordon, R.H., 1998. Can high personal tax rates encourage entrepreneurial activity? Staff PapersInternational Monetary Fund, pp.49-80.

Hall, B.H., 1987. The Relationship Between Firm Size and Firm Growth in the US Manufacturing Sector. The Journal of Industrial Economics, 35(4), pp.583-606.

Hannan, M.T. \& Carroll, G., 1992. Dynamics of organizational populations: Density, legitimation, and competition, Oxford University Press, USA.

Haveman, H.A., 1995. The demographic metabolism of organizations: Industry dynamics, turnover, and tenure distributions. Administrative Science Quarterly, pp.586-618.

Hopenhayn, H.A., 1992. Entry, exit, and firm dynamics in long run equilibrium. Econometrica: Journal of the Econometric Society, 60, pp.1127-1150.

Huyghebaert, N. \& Van de Gucht, L.M., 2004. Incumbent strategic behavior in financial markets and the exit of entrepreneurial start-ups. Strategic Management Journal, 25(7), pp.669688.

Huynh, K.P., Petrunia, R.J. \& Voia, M.C., 2008. Startup financial conditions and survival of new firms. In DRUID 25th Celebration Conference 2008. Copenhagen

Huynh, K., Petrunia, R. \& Voia, M.C., 2009. Fitness Versus Fatness: Productivity, Financial Conditions, and the Survival of New Canadian Manufacturing Firms. Available at SSRN: $\mathrm{http}: / /$ ssrn.com/abstract $=1470869$

Huynh, K.P., Petrunia, R.J. \& Voia, M.C, 2010. The impact of initial financial state on firm duration across entry cohorts. The Journal of Industrial Economics, 58(3), pp.661-689.

Jovanovic, B., 1982. Selection and the Evolution of Industry. Econometrica: Journal of the Econometric Society, 50, pp.649-670.

Jovanovic, B. \& Rousseau, P.L., 2001. Vintage organization capital, National Bureau of Economic Research. NBER Working Papers. Available at : http://econpapers.repec.org/RePEc:nbr:nberwo:8166

Kennickell, A.B., 1998. List Sample Design for the 1998 Survey of Consumer Finances. Board of Governors of the Federal Reserve Board. Available at: http://www. federalreserve. gov/pubs/oss/oss2/method. html.

Kennickell, A.B., 1997. Multiple imputation and disclosure protection: The case of the 1995 Survey of Consumer Finances. Record Linkage Techniques, 1997, pp.248-267.

Klepper, S. \& Simons, K.L., 2003. Dominance by birthright: entry of prior radio producers and competitive ramifications in the US television receiver industry. The SMS Blackwell Handbook of Organizational Capabilities: Emergence, Development, and Change, pp.1542. 
Kumar, M.S., 1985. Growth, acquisition activity and firm size: evidence from the United Kingdom. The Journal of Industrial Economics, 33(3), pp.327-338.

Lucas Jr, R.E., 1978. On the size distribution of business firms. The Bell Journal of Economics, pp.508-523.

Mata, J. \& Portugal, P., 1994. Life duration of new firms. The Journal of Industrial Economics, 13, pp.227-245.

Mata, J., Portugal, P. \& Guimaraes, P., 1995. The survival of new plants: Start-up conditions and post-entry evolution. International Journal of Industrial Organization, 13(4), pp.459481.

Mitchell, W., 1994. The dynamics of evolving markets: The effects of business sales and age on dissolutions and divestitures. Administrative Science Quarterly, pp.575-602.

Myers, S.C., 1977. Determinants of corporate borrowing. Journal of financial economics, 5(2), pp.147-175.

Poitevin, M., 1989. Financial signalling and the“ deep-pocket" argument. The RAND Journal of Economics, pp.26-40.

Robb, A., Ballou, J., DesRoches, D., Potter, F., Zhao, Z. and Reedy, E.J., 2009. An Overview of the Kauffman Firm Survey-Results from the 2004-2007 Data. Kauffman Foundation.

Robb, A. \& Coleman, S., 2009. The Impact of Financial Capital on Business Performance: A Comparison of Women-and Men-Owned Firms. Available at: SSRN: http://ssrn.com/abstract $=1400742$

Shane, S.A., 2008. The illusions of entrepreneurship: The costly myths that entrepreneurs, investors, and policy makers live by, Yale Univ Pr.

Sharma, A. \& Kesner, I.F., 1996. Diversifying entry: Some ex ante explanations for postentry survival and growth. Academy of Management Journal, pp.635-677.

Sutton, J., 1997. Gibrat's legacy. Journal of economic Literature, 35(1), pp.40-59.

Thompson, P., 2005. Selection and firm survival: Evidence from the shipbuilding industry, 18251914. Review of Economics and Statistics, 87(1), pp.26-36.

Wernerfelt, B., 1984. A resource-based view of the firm. Strategic management journal, 5(2), pp.171-180.

Youndt, M., Snell, S., Dean, J. \& Lepak, D., 1996. Human resource management, manufacturing strategy, and firm performance. Academy of management Journal, 39, pp.836-866.

Zingales, L., 1998. Survival of the Fittest or the Fattest? Exit and Financing in the Trucking Industry. The Journal of Finance, 53(3), pp.905-93. 


\section{CHAPTER 2}

\section{Firms' Survival within the Product-Service Spectrum using the KFS: How the Choice between Product or Service Influences Survival.}

\subsection{Introduction}

Services are a large and growing part of gross domestic product (GDP) (see Figure 2.1). Some scholars ${ }^{30}$ believe that because service industries are labor intensive and exhibit little productivity growth, the increasing share of GDP could result in lower economic growth. However, the emergence of new technologies contradicts this belief as they have played an important role, in that services have actually spread to many areas because of them (the Internet, smart phones, etc.). In addition, some studies $^{31}$ suggest that the growth associated to goods' productivity is partly the result of growth in the service sector. The literature has treated services fairly as non-tradable as opposed to goods that are highly tradable. Therefore the trade was highly dominated by good-providing firms, while service-providing firms were limited to the domestic market. With the emergence of the Internet ${ }^{32}$, SPs have seen their market grow and hence potential increase in revenues. Granted, not all services have become tradable, but firms can now consult, advise and diagnose online in exchange for payment. Furthermore, the development of new marketing strategies together with the evolution of technology has created an increasing amount of online firms providing services and being able to survive and even thrive.

Bhattacherjee (2001) discusses the effects of implementing a customer relationship management (CRM) program into e-commerce businesses and shows how beneficial this can be as it moves the business focus towards customer retention. Obviously, this technology explosion has contributed a lot to the growth of the service branch, but it is not the only reason that more

\footnotetext{
${ }^{30}$ Baumol (1967) and Baumol, Blackman and Wolff (1985).

${ }^{31}$ Raa and Wolff (1996).

${ }^{32}$ Freund and Weinhold (2002) found that the Internet contributed to a growth in service trade.
} 
firms are becoming service providers (SPs) or initially start out as SPs. Abraham and Taylor (1996) found that firms contract service providers in order to smooth production cycles and save on labor costs, allowing both companies to increase profits by lowering costs. Other possible explanations for the increase in SPs could be linked to the change in the labor force composition. For instance, the increase in labor supplied by women ${ }^{33}$ as well as in female entrepreneurship ${ }^{34}$ has contributed to the increase in SPs. Indeed, women are now overrepresented in the retail and service industries ${ }^{35}$. Another possibility is linked to new estimates in the literature that suggest that services may be income-inelastic ${ }^{36}$, allowing for greater customer retention. Entry rates may therefore have been higher for service providers, or they may be exiting at a slower pace. It could also be that more product provider firms are becoming service providers than vice versa. The likely explanation is a combination of all of the above.

Firms' survival has been covered extensively in the literature. Scholars have extensively researched the variables that contribute to survival in the hope of benefiting firms' future planning. The majority of determinants for survival studied so far fall into two distinct categories: firm $^{37}$ or industry ${ }^{38}$ specific variables. I am studying a new dimension that falls into the firm specific variable classification. Firms must also choose whether they are service providers (SPs), product providers (PPs) or providers of both service(s) and product(s) (PBs).

\footnotetext{
${ }^{33}$ Oppenheimer (1970).

${ }^{34}$ Kalleberg and Leicht (1991).

${ }^{35}$ Watson (2003).

${ }^{36}$ Falvey and Gemmell (1996).

${ }^{37}$ Size, experience, education, owners' profile, financial profile (assets, debt, debt-equity ratio, etc.) are very common variables in the literature. Klepper and Simons (2000), Thompson (2005), Geroski, Mata, Portugal (2010), Mata and Portugal (1994), Huynh, Petrunia and Voia, (2010) are empirical papers. Cooley and Quadrini (2001) is a reference at the financial theoretical level.

${ }^{38}$ Audretsch (1991) inspect the effects of industry specific variables on firms' survival. Audretsch and Mahmood (1994) and Åstebro and Bernhardt (2003) add firm specific variables to industry specific variables.
} 
Insofar as known, the study of firms' survival from the product-service spectrum has not been done. This paper represents an initial step towards understanding the consequences of this survival choice. Thus, the main motivation for this paper is to find evidence that the decision to be an SP or a PP significantly contributes to a firm's survival. I put forward the possibility that SPs are more likely to survive than PPs. Furthermore, there is also the possibility of providing both service(s) and product(s), which, according to Cohen and Whang (1997), is more advantageous. For example, if a firm offers extended warranties ${ }^{39}$ or maintenance to a consumer that purchases a new product, the firm is providing both a product and service. A maintenance program is seen as a long-term commitment from the consumer and a stream of revenue to the providing firm. Although it would be very interesting to study cases of providing both services and products, this paper will abstain from that in order to simplify the analysis.

Figure 2.1

Services as a Percentage of GDP in the U.S.

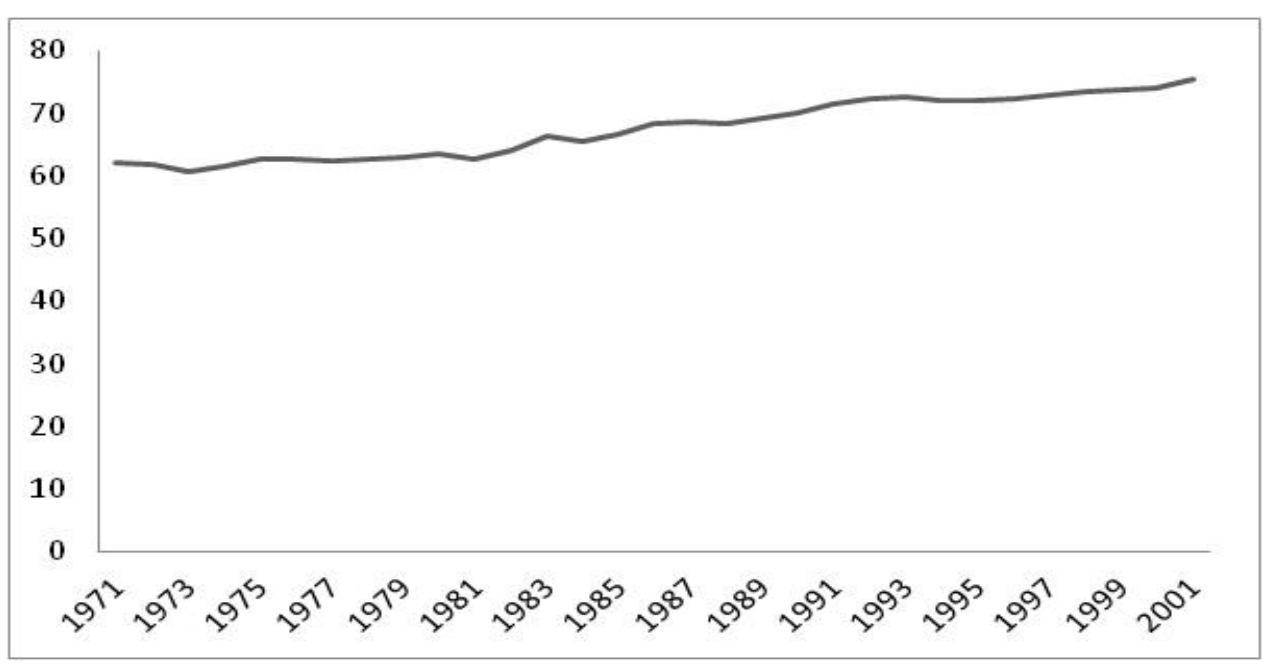

Source: World Bank national accounts data, and OECD National Accounts data files.

\footnotetext{
${ }^{39}$ Priest (2007) explains that there are two branches in the literature that adopt different views regarding extended warranties offered by manufacturers. The first, and oldest, sees warranties as contracts in which manufacturers limit their obligations and is a negative point to the consumer. The second branch explains that consumers can use warranties as a signaling device in order to evaluate product reliability. Thus, the first theory could be a possible contributor to PBs' and SPs' survival.
} 
I used the Kauffman Firm Survey, in which firms are asked whether they are providing a product, a service or both. Using a Cox proportional hazard model, I found that hazard increases when firms are good(s) providers as opposed to service(s) providers. I tested six hypotheses that could explain the causes of this hazard rate behavior. I allowed coefficients to differ depending on whether the firm was an SP, PP or PB. Although none of my stated hypotheses explain SPs' higher survival capabilities, I reviewed some studies suggesting (without testing because of a lack of data) that SPs' higher probability to evade taxes ${ }^{40}$ together with social psychology linked with human bonding and customer satisfaction could be the answer to SPs' higher survival ability, as a result of increased customer retention. For instance, mechanics rely on the confidence and trust their customers have in them. Bolton (1998) analyses SPs customer relations and suggests that customer satisfaction is important for customer retention.

The first section of the paper describes the Kauffman Firm Survey and provides summary statistics on the full data set. The second section describes the model used in the analysis. Hypotheses that could explain the possible causes of SPs' higher potential for survival when compared to PPs are introduced along with a literature review. The third section presents the results together with a little discussion of providers of both service(s) and product(s). Finally, I conclude the paper with a summary of the findings and a discussion for future research possibilities.

\subsection{The Data}

\section{- The Kauffman Firm Survey (KFS)}

I use the public release of the KFS, a panel data set covering a broad range of topics, allowing the study of a sample of firms created in 2004. The data set contains information on a

\footnotetext{
${ }^{40}$ Murray (1997) states:" Some retail firms, especially those with high value added (such as service providers), may choose not to register at all (for sales tax), in turn simply paying sales tax on their inputs."
} 
variety of topics, including financing, organizational structure and legal status, business characteristics and strategy, owner demographics and work behavior.

The KFS is taken from a random sample of businesses - from the Dun and Bradstreet (DB) database - created in 2004. The questionnaires sent to the sample were designed by the Mathematica Policy Research. The baseline questionnaire was sent in 2004, and because of the quest for a longitudinal database, follow-up questionnaires were sent every following year. So far, four follow-up waves consisting of 2005, 2006, 2007 and 2008 data have been added.

The development and change aspects involved with innovations in high-tech industries motivated the Foundation to oversample firms in these fields.

The screening/eligibility test allowed only 15 percent of the potential pool of firms to be part of the sample. The initial sample of firms passed "the eligibility test" defining a new business in 2004 and consisted of 4,928 firms out of an initial pool of 32,429 businesses. Respondents were paid $\$ 50$ to answer questions using a self-administered Web survey or a computer-assisted telephone interview. Eligibility was determined with two tests. A firm had to be a new company, and it had to be created individually by de novo entrepreneurs. The first test ensures that the company had started its activity in 2004. Therefore, if the firm had started activity in 2003 (or earlier) under any other form of structure, and the 2004 initial year of activity, for example, only marked a restructuring (e.g., sold business, renamed business, or changed activity), the firm did not qualify to be part of the sample. The second test checked ownership and provenance of the firm. It could not be a subsidiary of any other business, could not have been a spin off, nor inherited by previous owners. Finally, it could not be a not-for-profit company. Firms that passed both tests were part of the sample in the baseline questionnaire and follow-ups. As previously stated, there are five waves available in the current KFS. Firms that participated in the first wave satisfied two conditions. They first needed to be part of the baseline sample and to have survived the first year of activity. 
The possible reasons for exit were determined at the beginning of the survey. Firms that ceased operation temporarily were a small minority in the sample. I exclude these firms from the study because the survey extends five years. A firm that ceased operation temporarily (for example one that exits in 2005 and is seen to reappear in 2008) is dropped from the sample.

Table 2.1

Firms' Outcomes (2004-2008) ${ }^{41}$ in Percentages

\begin{tabular}{|lcccc|}
\hline Year & $\mathbf{2 0 0 5}$ & $\mathbf{2 0 0 6}$ & $\mathbf{2 0 0 7}$ & $\mathbf{2 0 0 8}$ \\
Survived & 92.3 & 84.2 & 74.6 & 67.6 \\
Closed operations & 5.3 & 11.7 & 19.8 & 26.6 \\
Sold to or merged with another business & 1.2 & 2.8 & 3.9 & 4.8 \\
Temporarily ceased operations or other & 1.2 & 1.3 & 1.8 & 1.1 \\
$\quad$ TOTAL & 100.0 & 100.0 & 100.0 & 100.0 \\
\hline
\end{tabular}

Source: Kauffman Firm Survey Microdata. Sample includes only surviving firms over the 2004-2007 period, and firms that have been verified as going out of business over the same period. The original sample size in 2004 was 4,928.

Within this study, any reason that causes the respondents to declare that the original business is no longer in operation under at least one of the original founders is defined as inactive $^{42}$ (46 observations were removed because the businesses in question either changed ownership or temporarily stopped operations). Businesses that were sold or that merged with other businesses were also described as closed because of this change in ownership. The data show that 4.8 percent of starting firms were sold by the end of 2008. Some of the surviving firms chose not to answer further questions, and sample weights were adjusted accordingly. A firm described as active in a given year had to have been described as active in all previous years.

\footnotetext{
${ }^{41}$ From Robb et al. (2010) "An overview of the Kauffman Firm Survey", Results from the 2004-2008 Data”.

${ }^{42}$ Failure is defined differently between various studies. Hall (1987) considers mergers to be the exit of two firms into the creation of a new firm. The creation of a new firm is irrelevant to my study.
} 
Table 2.2

Firms' Distribution by Industry ${ }^{43}$ in Percentages

\begin{tabular}{|c|c|c|c|}
\hline Industry Names and (Code) & $\begin{array}{l}\text { KFS New } \\
\text { Employer } \\
\text { Businesses }\end{array}$ & $\begin{array}{c}\text { Census } \\
\text { Employer } \\
\text { Firm } \\
\text { Births }\end{array}$ & $\begin{array}{c}\text { PSED } \\
\text { New } \\
\text { Businesses }\end{array}$ \\
\hline $\begin{array}{l}\text { Professional (54), Management, and } \\
\text { Educational Services (61) }\end{array}$ & 16.1 & 14.1 & 16.8 \\
\hline Retail Trade (44) & 15.6 & 12.0 & 18.6 \\
\hline $\begin{array}{l}\text { Administrative and Support, and Waste } \\
\text { Management and Remediation Services (56) }\end{array}$ & 11.4 & 6.0 & 2.1 \\
\hline Construction (23) & 9.8 & 15.7 & 10.0 \\
\hline $\begin{array}{l}\text { Other Services (except Public Administration) } \\
\text { (81) }\end{array}$ & 8.0 & 8.5 & 0.3 \\
\hline Manufacturing (31) & 7.2 & 3.2 & 3.5 \\
\hline Wholesale Trade (42) & 6.0 & 4.5 & 1.5 \\
\hline Real Estate, Rental and Leasing (53) & 3.7 & 5.1 & 5.3 \\
\hline Finance and Insurance (52) & 4.7 & 2.2 & 3.1 \\
\hline Health Care and Social Assistance (62) & 4.2 & 7.7 & 2.9 \\
\hline Information (51) & 2.6 & 1.4 & 4.2 \\
\hline Transportation and Warehousing (48) & 2.9 & 3.3 & 2.4 \\
\hline Arts, Entertainment, and Recreation (71) & 3.1 & 2.1 & 3.2 \\
\hline Accommodation and Food Services (72) & 3.9 & 9.1 & 10.9 \\
\hline $\begin{array}{l}\text { Agriculture, Forestry, Fishing, and hunting } \\
\text { (11) }\end{array}$ & 1.4 & 0.4 & 2.0 \\
\hline Mining (21) & 0.0 & 0.3 & 0.5 \\
\hline Utilities (22) & 0.0 & 0.1 & 0.5 \\
\hline $\begin{array}{l}\text { Management of Companies and Enterprises } \\
\text { (55) }\end{array}$ & 0.0 & 0.1 & 6.7 \\
\hline Unclassified (99) & 0.0 & 2.2 & 5.6 \\
\hline
\end{tabular}

Source: Kauffman Firm Survey, Baseline data: Tabulations by Mathematica Policy Research, Inc; and Office of Advocacy, U.S. Small Business Administration, from longitudinal data (established with some first-quarter payroll) provided by the U.S. Census Bureau; Reynolds, P. 2004. Entrepreneurship in the United States Assessment, Miami, Fla: Florida International University.

${ }^{43}$ From Robb et al. (2010) "An overview of the Kauffman Firm Survey”, Results from the 2004-2007 Data". 
Some firms surveyed may also be firms that were created to reduce an individual's taxes. Prior research, both theoretical and empirical (Åstebro and Bernhadt, 2003; Gordon, 1998), has shown that paying fewer taxes could be one incentive for individuals to create companies. This is because corporate tax rules are often advantageous compared to income tax. Some of the firms surveyed were therefore likely to have been created as tax shelters. I chose to correct for this issue by removing firms that reported no sales in all years of activity ( 47 observations were deleted).

The distribution of firms by industry shows that in comparison to the U.S Census, the KFS has a higher proportion of businesses in multiple industries including manufacturing, professional management, education, retail and wholesale, finance and insurance. However, the KFS has a lower proportion of firms in construction, health care and social assistance, and accommodation and food services (see Table 2.2).

The sample surveyed shows that the majority of firms start as small, with fewer than five employees (75.1 percent). Also, the distribution of firms by size shows similarities with the Census. For example, 10.35 percent of the KFS sample startup with ten or more employees, compared to 10.4 percent $^{44}$ in the Census. Table 2.3 shows that the KFS was not able to capture any firm in its sample with 500 employees or more. The Foundation suggests this could be because few firms have the capacity to begin at such a large scale.

The KFS reports a 92.3 percent survival rate in the first year of activity. This rate is higher than those found in previous studies. For instance, the U.S. Small Business Administration found the survival rate of single-establishment firms founded in 1997 was only 75 percent in the first year. The $\mathrm{CBO}$ has found rates similar to the U.S. Small Business Administration for different cohorts of single-establishment firms (Shane, 2008). The KFS could be registering higher rates for a simple reason: firms created in the beginning of 2004 and closing shortly after may have been omitted from the sample due to the screening method. Therefore, a firm that

\footnotetext{
${ }^{44}$ Robb, Ballou, DesRoches, Potter, Zhao and Reedy (2010).
} 
would have closed before the baseline survey was issued in 2005 could not be part of the sample ${ }^{45}$

Table 2.3

Distribution of Firms by Employment Size Category ${ }^{46}$ in Percentages

\begin{tabular}{|ccc|}
\hline Number of Employees & KFS New businesses & Census New Businesses \\
$\mathbf{1 - 4}$ & 75.1 & 76.7 \\
$\mathbf{5 - 9}$ & 14.6 & 13.0 \\
$\mathbf{1 0 - 1 9}$ & 6.6 & 6.0 \\
$\mathbf{2 0 - 9 9}$ & 3.4 & 3.8 \\
$\mathbf{1 0 0 - 4 9 9}$ & 0.3 & 0.4 \\
$\mathbf{5 0 0 +}$ & 0.0 & $0.0^{47}$ \\
\hline
\end{tabular}

Source: Kauffman Firm Survey, Baseline data; Office of Advocacy, U.S. Small Business Administration, Statistics of U.S. businesses, U.S. Census, 2004.

The KFS baseline questionnaire and following waves ask whether the interviewed firm would describe itself as a service(s) provider (SP), product(s) provider (PP) or as providing both service(s) and product(s) (PB). Thus, each firm could only be classified in one part of the "product-service spectrum." Some firms chose not to answer, and I treat them as missing data in this study. Table 2.4 shows that SPs seem to be the biggest part of the sample every year while PPs remain a smaller part of the sample as time passes. The PBs segment seems to be the only one not monotonically decreasing as a percentage of the sample. Indeed, they became a larger part of the sample from 2004 to 2005 and from 2007 to 2008. It could be because some of the firms that were only providing services or products decided to provide both.

\footnotetext{
${ }^{45}$ Hall (1987) suggests that the sample bias created by the earlier death probability of younger firms is not a problem in her study of growth.

${ }^{46}$ From Robb et al. (2010) "An overview of the Kauffman Firm Survey", results from the 2004-2007 data".

${ }^{47}$ This number rounds to 0.0 . Actual number is 0.04 .
} 
Table 2.4

The Sample of the Surviving Population by Provider Categories in Percentages

\begin{tabular}{|cccccc|}
\hline $\begin{array}{c}\text { Provider } \\
\text { Category } \\
\text { PB }\end{array}$ & $\mathbf{2 0 0 4}$ & $\mathbf{2 0 0 5}$ & $\mathbf{2 0 0 6}$ & $\mathbf{2 0 0 7}$ & $\mathbf{2 0 0 8}$ \\
SP & 37.4 & 38.4 & 36.1 & 34.5 & 35.0 \\
PP & 48.0 & 41.3 & 40.6 & 38.4 & 36.8 \\
Missing Data & 14.3 & 11.3 & 10.1 & 9.6 & 9.1 \\
\hline
\end{tabular}

Source: Tabulation of the Kauffman Firm Survey, 2010 release.

Between 2004 and 2005, 20.3 percent (139) of the PPs decided to provide both services and products by 2005. For comparison, only 11.3 percent (259) of the SPs in 2004 provided both services and products in 2005. Moreover, 14.3 percent (256) of the firms providing both services and products in 2004 stopped providing products (became SP) and 5.8 percent (104) stopped providing services (became PP). Also 0.6 percent (15) of SPs in 2004 became PPs in 2005 and 3.5 percent (24) of the PPs in 2004 became SPs in 2005. Overall, the statistics reflect a trend in the firms' desire to move away from providing products. Also, it is more likely that a firm will move from PPs to PBs than from SPs to the PBs category. Keeping in mind that a firm's best strategy is whatever maximizes its profits given its skill and resources (and referring to Jovanovic, 1982), the trend suggests a desire for firms to move into the PBs group. It may also be harder to operate as a PP than as an SP, as it is easier to add services to your portfolio if you already are providing a product than adding products if you are an SP, as that entails a larger sunk cost. A closer look at the numbers shows that a large number of the PBs have a preference for services, as they seem to continue providing services when deciding whether to provide services or products (14.3 against 5.8 percent). Another possibility is that SPs are more likely to survive than the PPs group. The higher failure rates associated with PPs can be seen in the representation of the Kaplan-Meier surviving function (see Figure 2.2). 
Figure 2.2

Kaplan-Meier Survival Graph

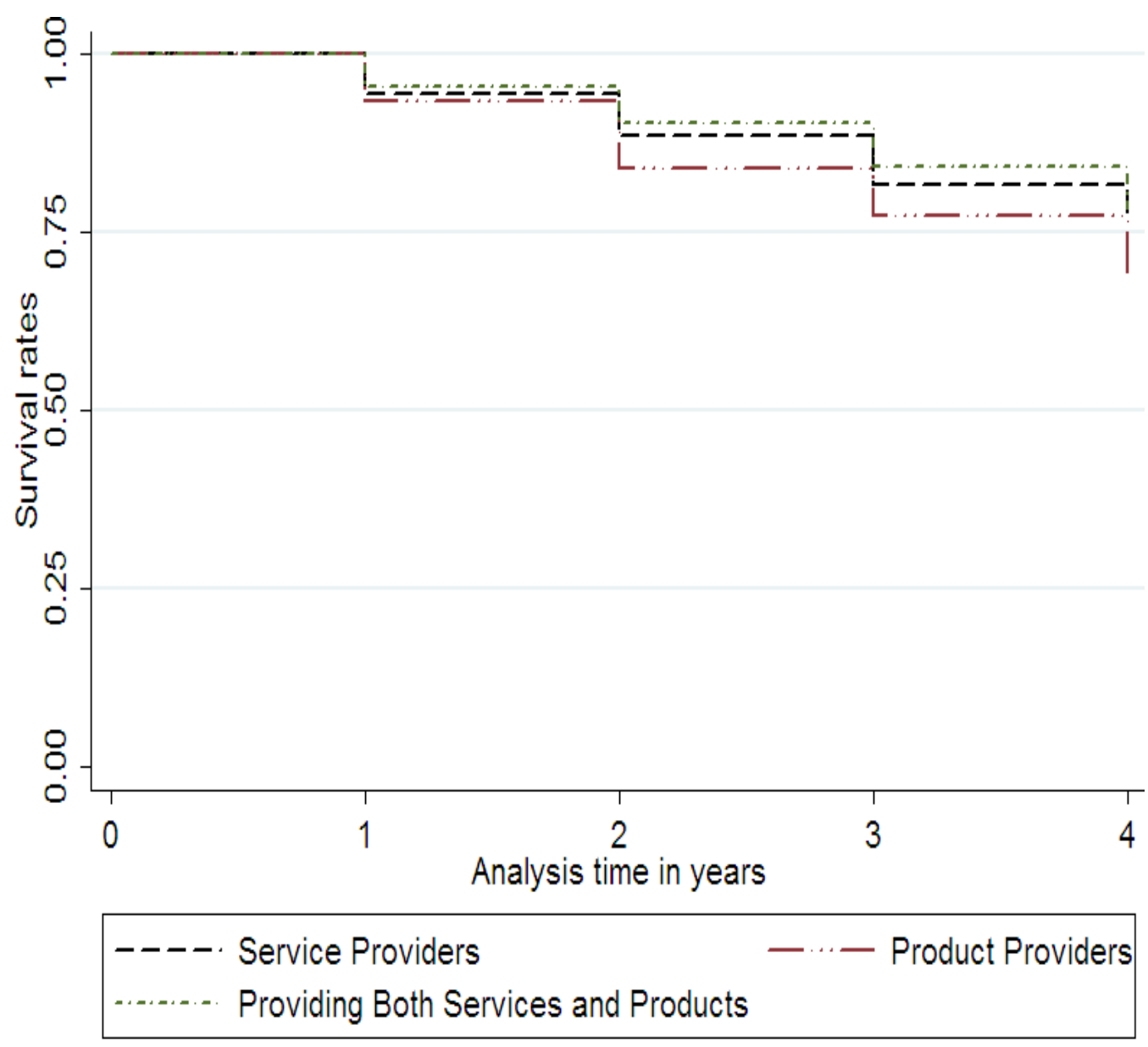

- Added data from the U.S. Bureau of Labor Statistics (BLS)

I created an industry wage variable that was built using information published in the Monthly Labor Review by the BLS dating from March 2008. The BLS published the seasonally adjusted average hourly earnings for some industries in 2005, 2006 and 2007. Thus, I needed to build the data for 2004 and 2008. I proceeded by assuming a linear relationship calculating the average growth rate from 2004 to 2005 and 2005 to 2006 . This average growth was then used to calculate an approximation of the average hourly wage by industry in 2004 and 2008. The results can be found in Table 2.5. 
Table 2.5

Industries' Average Wage

\begin{tabular}{cccccc}
\hline NAICS & $\begin{array}{c}\text { Estimated } \\
\text { Wage 04 }\end{array}$ & Wage 05 & Wage 06 & Wage 07 & $\begin{array}{c}\text { Estimated } \\
\text { Wage 08 }\end{array}$ \\
\hline 11 & 17.68 & 18.72 & 19.90 & 20.99 & 22.23 \\
23 & 18.76 & 19.46 & 20.02 & 20.94 & 21.72 \\
31 & 11.47 & 12.06 & 12.98 & 13.32 & 14.00 \\
32 & 15.89 & 16.51 & 17.49 & 17.83 & 18.53 \\
33 & 16.85 & 17.05 & 17.22 & 17.46 & 17.67 \\
42 & 17.50 & 18.16 & 18.91 & 19.56 & 20.30 \\
44 & 12.15 & 12.36 & 12.58 & 12.80 & 13.03 \\
48 & 16.19 & 16.70 & 17.28 & 17.76 & 18.32 \\
22 & 26.08 & 26.68 & 27.42 & 27.93 & 28.58 \\
51 & 21.18 & 22.06 & 23.23 & 23.92 & 24.91 \\
52 & 17.14 & 17.94 & 18.80 & 19.66 & 20.58 \\
53 & 16.18 & 16.76 & 17.32 & 17.99 & 18.64 \\
54 & 17.13 & 18.08 & 19.12 & 20.15 & 21.27 \\
55 & 25.83 & 27.13 & 28.41 & 29.93 & 31.44 \\
56 & 13.75 & 14.19 & 14.56 & 15.11 & 15.59 \\
61 & 16.09 & 16.71 & 17.38 & 18.03 & 18.73 \\
71 & 8.90 & 9.38 & 9.75 & 10.41 & 10.97 \\
81 & 13.92 & 14.34 & 14.77 & 15.22 & 15.68 \\
\hline
\end{tabular}

\subsection{The Model}

- The Cox Proportional Hazard Model: A semi-parametric specification

The most appropriate method of analysis to be used in survival analysis is unambiguously the hazard model. I do not assume any distribution for the failure time. Subsequent to the trend set by the literature, this paper follows a semi-parametric specification and uses the Cox proportional hazard model (Cox, 1972). The model can be written as:

$$
h_{j}(t)=h_{0}(t) e^{\left(\beta_{0}+x_{j} \beta_{x}\right)}
$$


where $h_{j}$ represents the hazard faced by subject $j$ and $h_{0}$ the baseline hazard that everyone faces $^{48}$. The subject hazard function is therefore a multiplicative of the baseline hazard adapted through an $x_{j}$ vector specific to the firm $j$. An advantage of using the Cox model is that the baseline hazard function does not need to be determined. The reason behind this helpful characteristic is its cancelation when performing calculations in a binary-outcome analysis. The disadvantage of the Cox model is that it imposes proportional hazards.

The specific model used in this study allows each independent variable within $\mathbf{x}_{\mathbf{j}}$ to have different coefficients $\beta$ whether the firm $j$ is a service provider, a product provider or a provider of both. Indeed, it seems logical that some variables may have different effects on the firm whether it is a service provider, a product provider or a provider of both. So far, in the literature, the results associated with all the variables known to be good predictors of survival were never studied from this perspective. This study offers a new point of view on the matter ${ }^{49}$.

\section{- $\quad$ The hypotheses}

There are six possible hypotheses studied in this paper for service providers to have a higher survival probability than product providers. These potential explanatory variables were picked from the literature because they are known to be predictors of survivability. Some of the hypotheses also emerged because SPs and PPs differ drastically in those variables. A summary of means can be found in Table 2.6.

\footnotetext{
${ }^{48}$ I control for industries fixed effects and run robust regressions.

${ }^{49}$ I ran two Wald tests with chi-squared distribution for each variable used in the analysis to determine whether the coefficients are significantly different for SPs, PPs and PBs and if any of the variables would have SPs and PPs coefficient jointly equal to 0. The results can be found in Appendix 2.1. The null hypotheses are: $\beta_{S P}=\beta_{P P}=\beta_{P B}$ and $\beta_{S P}=\beta_{P P}=0$
} 
Table 2.6

Variables' Mean

\begin{tabular}{|c|c|c|c|}
\hline Variables & $\begin{array}{c}S P S \\
\text { Mean }\end{array}$ & $\begin{array}{c}P P S \\
\text { Mean } \\
\end{array}$ & $\begin{array}{c}P B \\
\text { Mean } \\
\end{array}$ \\
\hline Capital per worker & $\begin{array}{c}36,900 * * * \\
(14,700)\end{array}$ & $\begin{array}{c}52,200 * * * \\
(3,080)\end{array}$ & $\begin{array}{c}49,800 * * * \\
(1,940)\end{array}$ \\
\hline Expenses per worker & $\begin{array}{c}51,204 * * * \\
(1,255)\end{array}$ & $\begin{array}{c}61,997 * * * \\
(2,684)\end{array}$ & $\begin{array}{c}65,099 * * * \\
(1,682)\end{array}$ \\
\hline Total expenses & $\begin{array}{c}162,911 * * * \\
(3,277)\end{array}$ & $\begin{array}{c}232,647 * * * \\
(7,661)\end{array}$ & $\begin{array}{c}232,637 * * * \\
(4,428)\end{array}$ \\
\hline Owners' experience & $\begin{array}{c}13.48 * * * \\
(0.126)\end{array}$ & $\begin{array}{c}10.56^{* * *} \\
(0.243)\end{array}$ & $\begin{array}{c}12.35^{* * *} \\
(0.141)\end{array}$ \\
\hline Size & $\begin{array}{c}3.524 * * * \\
(0.0601)\end{array}$ & $\begin{array}{c}4.290 * * * \\
(0.136)\end{array}$ & $\begin{array}{c}4.443 * * * \\
(0.0817)\end{array}$ \\
\hline Total assets & $\begin{array}{c}101,300 * * * \\
(3,370)\end{array}$ & $\begin{array}{c}192,700 * * * * \\
(9,900)\end{array}$ & $\begin{array}{c}174,400 * * * \\
(5,420)\end{array}$ \\
\hline Industry wage & $\begin{array}{c}17.06 * * * \\
(0.0336)\end{array}$ & $\begin{array}{c}15.79 * * * \\
(0.0744)\end{array}$ & $\begin{array}{l}16.44 * * * \\
(0.0466)\end{array}$ \\
\hline Observations & 6,267 & 1,620 & 4,560 \\
\hline
\end{tabular}

Standard errors in parentheses

$* * * \mathrm{p}<0.01, * * \mathrm{p}<0.05, * \mathrm{p}<0.1$

An important aspect that differentiates SPs from PPs is the amount of capital used in both segments. Product providers are more capital intensive than service providers and both Audretsch (1991) and Audretsch and Mahmood (1994) found that capital-intensive industries tend to increase the hazard and could be the result of the larger investments required by higher-scale industries, which makes them harder to operate. The increase in the hazard can be counterbalanced with a higher startup size. In my study, the total assets value represents the sum of the firm's total equipment, its total inventory, its real estate ownership and finally the vehicles bought and registered under the firm's name. In order to control for the size effect of total assets, I divided it by the number of workers to create value of assets per worker.

H1: Capital intensity is a negative predictor of survival. Product providers, on average, are more capital intensive than service providers. Capital intensity will explain the higher probability of exit for a product provider. 
Differing levels of expenses are another possible explanation for the greater likelihood of survival of service providers over product providers. As shown in Table 2.6, product providers have higher expenses on average than service providers. Huyhebaert, Gaeremynck, Roodhooft and Van de Gucht (2000) explain that firms with higher fixed coverage expenses are expected to fail because banks will charge them a higher interest rate, and thus a larger part of the firm's funds will have to be paid to debt providers, meaning the firm has less for future investment. One could argue that expenses could be a proxy for size and that these two variables could therefore be highly correlated. This is a reasonable argument, and hence I created a variable that measures expenses per worker. This variable should allow the study of expenses while controlling for the size effect.

H2: Higher expenses per worker will increase firms' failure rates. Product providers, on average, have more expenses per worker than service providers. Higher expenses per worker explain the higher probability of exit for a product provider.

Human capital is a very important predictor of survival. Together with size, it could also be the most studied predictor of survival. Pre-entry experience relevant to the industry has also been shown to be an important variable in survival studies. The survey reports the years of industry-specific experience each owner had before the creation of the firm. Owners' previous industry experience can act as a proxy for human capital. After showing pre-entry relevant experience to be a good proxy for a firm's quality, Thompson (2005) affirms that relevant experience does indeed have persistent effects on survival and that these effects do not decay over time. Geroski et al. (2010) indirectly test the hypothesis ${ }^{50}$ that human capital is the main factor that provides firms with an edge because it cannot be replicated by competitors. They use education as a proxy for human capital and find that education reduces the hazard of exit. Lucas

\footnotetext{
${ }^{50}$ Following previous research such as Barney, 1991; Wernerfelt, 1984 and Youndt, Snell, Dean and Lepak, 1996.
} 
(1978) shows that having better quality human capital allows a firm to lower its cost at any given level of production. The intuition is that the more experienced the owners are in the related industry prior to starting the firm, the higher the probability for the firm to be of a higher quality. I constructed the variable for the firm's experience by calculating the mean experience brought in by each owner. The survey has an upper bound for years of experience equal to 40 years. If the corresponding owner has 41 or more years of experience, he or she is registered as having $40+$ years of experience, bringing me to censor the years of experience variable from above and lock it to a maximum of 40. Assuming decreasing returns to experience, censoring from above should have little or no consequence. The argument could be made that mean owners' relevant experience is not the best measure of the firm's experience. An average weighted according to the time put in the company by each owner would be a better measure. The more an owner works in the company, the higher the weight of his experience. Unfortunately, this method is impossible to apply given the data.

H3: Higher owners' experience will decrease the hazard on survival. Product providers with a lower average experience increases the hazard rate when compared to service providers.

Industry wage is another measure positively related to survival. Audretsch and Mahmood (1994) explain that industries with higher wages tend to express higher investment in human capital or labor-related sunk costs. Thus, industry wage proxies for human capital in the industry in which the firm operates. Product providers have, on average, smaller industry wages and higher industry wage is likely to be a positive predictor of survival, as demonstrated in Audretsch and Mahmood (1994). Thus product providers could be at a disadvantage compared to service providers.

H4: Industry wage will decrease the hazard rate. Product providers with a lower average wage are disadvantaged when compared to service providers. 
As mentioned, the "total assets" Kauffman Firm Survey. Those variables are range variables. Operations are not possible on range variables, so I have used the ranges' midpoints as a point of reference (I did not have access to the ranges' means and medians). The use of midpoints to proxy for the range values has been used in previous research, ${ }^{52}$ including some working papers using the $\mathrm{KFS},{ }^{53}$ and is accepted as an admissible replacement for the real values.

Asset values are book values and therefore subject to depreciation. Asset value could be used as a proxy for size, and therefore, tone might expect total assets to react as a variable in the same way as size. However, the new findings are expressed in the results. Allowing for different slopes for SPs, PPs and PBs allows a determination of whether asset size could actually play a negative role in survival, depending on firms' activities. As far as I am aware, there has been no previous research on this aspect.

So far, researchers have reported a general positive effect of size (and thus assets) on survival (Geroski et al, 2010; Mata and Portugal, 1994). One possible reason is that the higher the asset stock at creation, the more positive the message sent to debt institutions and therefore, the more access a firm has to debt to finance its growth. However, the fewer assets tied to the business, the more opportunities the firm has to readjust its products and services. Moreover, a firm's assets are subject to depreciation, which is incurred as a cost. As such, I believe that once size is controlled for in $H 6$ (assuming it to be positive on survival), the real effect of total assets

\footnotetext{
${ }^{51}$ The survey classifies financial information under range variables.

${ }^{52}$ Kennickell (1998) suggests that the range variables reported in the Survey of Consumer Finances are a limitation to research and thus suggests in Kennickell (1999) that the midpoints of the respective ranges are used.

${ }^{53}$ The working paper by Braymen and Neymotin entitled "Immigrant enclaves and the success of entrepreneurial ventures" (2011) assigned midpoints to the range variables whenever the respondent was asked to choose a range in the KFS. Robb and Coleman's working paper entitled "The impact of financial capital on business performance: a comparison of women- and men-owned firms" (2009) used a similar approach.
} 
should increase the hazard rate and therefore have a negative effect on survival. Referring to Table 2.6, note that product providers have more assets on average than service providers.

H5: Total assets should decrease firms' failure rates. However, once size is controlled for, total assets will increase the firms' hazard rates. Product providers with higher average assets value will be more likely to exit than service providers.

Some studies have been conducted on the determinants of growth over time, while others have focused on the initial starting size (Audretsh and Mahmood, 1994; Dunne, Roberts and Samuelson, 1989; Geroski et al., 2010; Haverman, 1995; Mata and Portugal, 1994; Mitchell, 1994; Sharma and Kesner, 1996). A simple reason for the higher failure rate of smaller firms is that larger firms have the option to downsize when needed (cut expenses). Moreover, in difficult times, larger firms can withdraw from dying markets and refocus on more viable options. The possibility to withdraw from markets is more difficult for smaller firms because of the smaller scope of their operations. Others ${ }^{54}$ have suggested that larger firms are less susceptible to financial constraints and therefore have access to funds to weather difficult times or even to finance projects. An interesting alternative explanation deals with the costs of production. There are lower per unit costs associated with producing on a large scale (Lucas, 1978). The bigger a firm is, the closer to the minimum efficient scale (MES) of production it is and the lower its costs of production. The lower costs associated with the MES theory could happen for two reasons. First, a larger size allows the firm to operate further down the cost curve. The second reason is that fewer financial constraints allow the firm to operate at a higher scale. Geroski et al. (2010) also report a non-instantaneous increase in survival prospects as a firm's size increases, which is partly consistent with Jovanovic (1982) who states that firms adjust their size (by learning about their efficiency as time goes by) according to past performance, and only current size matters in

\footnotetext{
${ }^{54}$ Fazzari, Hubbard and Petersen (1988) was a pioneer paper that asked the cash flow effect on investment question. Zingales (1998), like Fazzari et al. (1998), study the effect of capital market imperfections on survival. They find that highly leveraged firms are less likely to survive.
} 
predicting survivability. Another interesting possibility is that entering larger in size sends a positive signal and relaxes liquidity constraints proposed by Evans and Jovanovic (1989). On average, product providers are bigger than service providers. I built a size variable using the total number of employees including operating owners.

H6: Size as expressed in numbers of employees will decrease the hazard rate. Product providers are larger on average, and therefore do not explain why product providers have a lower survival likelihood.

\subsection{Empirical Analysis}

I first ran a basic regression that showed being a PP increased the hazard rate by 35.5 percent $(\exp (0.304)=1.3552)$ compared to an SP (variable omitted from the regression). The results are reported in Table 2.7. I ran two types of regressions. The first helped me understand whether one hypothesis alone was responsible for the results found in the base model. Subsequently, I ran a second set of regressions adding one variable at a time to each previous model. I had six hypotheses, and therefore each set of regression had six models on top of the base model. The different Wald tests (chi-squared distribution) rejected the null hypothesis ${ }^{55}$ except those run on expenses per worker, owner's experience and the industry wage variable ${ }^{56}$. Therefore all variables beside these three variables are allowed to have different $\boldsymbol{\beta}$ s for service providers, product providers, and providers of both.

- Survival analysis—testing one hypothesis at a time

The variable PP is always significant, no matter which explanatory variable is used in the Model. This consistent significance on PP points to the fact that none of the hypotheses alone can explain the higher probability of product providers exiting when compared to service providers.

\footnotetext{
${ }^{55}$ The null hypothesis states that all three groups' coefficients are equal for each variable in the vector $\mathrm{x}$.

${ }^{56}$ The results are reported in Appendix2.1.
} 
Although I cannot come to any conclusion using these results, I can however examine how each variable influences PPs' and SPs' survival.

Table 2.7

Individual Regressions

\begin{tabular}{|c|c|c|c|c|c|c|c|}
\hline VARIABLES & $\begin{array}{c}\text { Base } \\
\text { Model }\end{array}$ & Model 1 & Model 2 & Model 3 & Model 4 & Model 5 & Model 6 \\
\hline \multirow[t]{2}{*}{$\mathrm{PP}$} & $0.304^{* *}$ & $0.341^{* *}$ & $0.292 * * *$ & $0.273^{* *}$ & $0.303^{* *}$ & $0.293^{* *}$ & $0.220^{*}$ \\
\hline & $(0.105)$ & $(0.117)$ & $(0.108)$ & $(0.107)$ & $(0.105)$ & $(0.117)$ & $(0.133)$ \\
\hline \multirow[t]{2}{*}{ PB } & $-0.128 *$ & -0.107 & -0.105 & $-0.136^{*}$ & $-0.129 *$ & -0.0844 & $-0.226^{* *}$ \\
\hline & $(0.0774)$ & $(0.0843)$ & $(0.0791)$ & $(0.0787)$ & $(0.0774$ & $(0.0843)$ & $(0.104)$ \\
\hline SP capital per & & -0.0799 & & & & & \\
\hline Worker & & $(0.0510)$ & & & & & \\
\hline PP capital per & & $-0.228 * *$ & & & & & \\
\hline Worker & & $(0.111)$ & & & & & \\
\hline PB capital per & & -0.0746 & & & & & \\
\hline Worker & & $(0.0621)$ & & & & & \\
\hline Expenses per & & & $-0.0171 * * *$ & & & & \\
\hline Worker & & & $(0.00498)$ & & & & \\
\hline Owners' & & & & $-0.0164 * * *$ & & & \\
\hline Experience & & & & $(0.00387)$ & & & \\
\hline Industry wage & & & & & $\begin{array}{c}-0.106 \\
(0.0980\end{array}$ & & \\
\hline SP assets & & & & & & $\begin{array}{c}-0.0559 * * \\
(0.0249)\end{array}$ & \\
\hline PP assets & & & & & & $\begin{array}{c}-0.0613^{*} \\
(0.0338)\end{array}$ & \\
\hline PB assets & & & & & & $\begin{array}{c}-0.0658 * * * \\
(0.0222)\end{array}$ & \\
\hline SP size & & & & & & & $\begin{array}{c}-0.0802 * * * \\
(0.0191)\end{array}$ \\
\hline PP size & & & & & & & $\begin{array}{c}-0.0480 * * \\
(0.0217)\end{array}$ \\
\hline PB size & & & & & & & $\begin{array}{c}-0.0373 * * * \\
(0.0134)\end{array}$ \\
\hline Observations & 14,881 & 13,887 & 14,164 & 14,335 & 14,873 & 14,170 & 14,621 \\
\hline
\end{tabular}

Robust standard errors in parentheses,

$* * * \mathrm{p}<0.01, * * \mathrm{p}<0.05, * \mathrm{p}<0.1$

First, the only significant coefficient found in the first model is the one associated with PP's capital per worker despite the signs on all coefficients confirming a decrease in the hazard rate with an increase in capital per worker and thus rejecting hypothesis 1 . It seems that capital per worker only plays a significant role when the firm is a product provider. The second model, which tests expenses per worker, returns a significant negative coefficient as well, and $H 2$ is also 
rejected. The third model supports $H 3$, and the coefficient is highly significant proving again that owner's experience is an important contributor to a firm's survival. The fourth model returns an insignificant coefficient ${ }^{57}$ with a sign confirming the literature ${ }^{58}$ hence supporting the hypothesis 4. Moreover, in the fifth model, PPs benefit more from an increase in assets ${ }^{59}$ (although this model does not control for size). The coefficients in Model 6 are significant, but the magnitude comparison between SPs and PPs is rather surprising. The coefficients on size seem to indicate a higher marginal contribution toward survival for service providers. Overall, $H 3$ and $H 6$ are supported while $H 5$ is not relevant because I do not control for size in the fifth model.

- Survival analysis with developed model

Table 2.8 shows the results for this analysis. The first model adds capital per worker to the base model. The PP coefficient is still highly significant, and the hazard magnitude went up, which means that capital per worker is actually a positive predictor of survival for PP and provides an advantage to PPs as compared to SPs (note that the increase in PP coefficients from the base model to Model 1 is lower than the standard errors). Therefore I can reject the hypothesis 1. The significant coefficient found for "PP capital per worker" tells the same story. In the base model, capital per worker was embedded within the model and kept the PP hazard coefficient down. When capital per worker is controlled for, the coefficient on PP goes up. Although capital per worker is always beneficial to survival, this variable proves to be a more important contributor to survival for PPs (a higher coefficient than SPs in absolute value). Table 2.6 shows that PPs have higher capital per worker on average. An increase of $\$ 100,000$ reduces the hazard by only 7.7 percent $(\exp (-0.0799)=0.9232)$ for SPs when it reduces the hazard by 20.39 percent

\footnotetext{
${ }^{57}$ This confirms the result found in Appendix 2.1 for industry wage.

${ }^{58}$ See Audretsch and Mahmood (1994).

${ }^{59}$ According to Baumol (1967) and Baumol et al. (1985), service providers are labor intensive as opposed to good providers that are capital intensive.
} 
$(\exp (-0.228)=0.7961)$ for PPs. This clearly shows the importance of capital per worker for product providers.

The second model adds expenses per worker to the first model. The coefficient on PP remains significant. The model clearly rejects $H 2$, and higher expenses per worker reduce failure probability. An increase of $\$ 100,000$ in expense per worker decreases the exit probability by a little more than 1.5 percent $(\exp (-0.0159)=0.9842)$, and the coefficient on expenses per worker is significant.

Owners' experience is added in the third model and the coefficient on PP is still significant. Each additional year of experience reduces the hazard by only 1.55 percent (exp ($0.0156)=0.9845)$ for all three groups. The coefficient on PP has gone down in the third model (decrease is lower than the standard errors), which is in concordance with the means reported in Table 2.6 where we can see that SPs are, on average, more experienced than product providers. Hence, the effects of owners' experience increased the hazard on PP when it was not controlled for. Experience is clearly a contributor to SPs higher survival probability, but the difference in coefficients between the second model and the third model suggests it is not the main predictor I was looking for. Thus, $H 3$ is partly supported.

Industry wage is added in the fourth model and has no effect on the PP coefficient. Industry wage is a proxy for experience. The higher the industry wage, the more likely firms have invested in human capital formation - training, management, higher percentage of white collar jobs. The coefficient associated with industry wage is insignificant, although its economic effect seems to be confirming the literature ${ }^{60}$, namely a positive predictor of survival. Thus, I can neither reject nor support the hypothesis 4 .

\footnotetext{
${ }^{60}$ See Audretsch and Mahmood (1994).
} 
Model 5 adds total assets and the results confirm the first part of H5; namely, the coefficients associated with the different assets groups are indeed negative (the coefficient on PP is statistically insignificant) and thus total assets stock decreases the firms' failure rate when size is not controlled.

Size is added in the last model making Model 6 the most complete model. As expected, the coefficients on total assets are now positive for both SPs and PPs (and statistically significant for PPs), while the coefficients on size are now negative. Thus, once size is controlled for, total assets value does indeed increase the firms' failure rates while size decreases them, confirming the second part of the hypothesis 5. Once I control for the positive effect of size, total assets increase the hazard rate. More assets mean higher sunk costs. On the one hand, this can be interpreted as a reduction in the available capital, resulting in a firm limiting its ability to finance future growth. On the other hand, higher sunk costs are often wrongly interpreted as being tied up in a business by entrepreneurs, who therefore seek to prolong the firm's life. The entrepreneurs' desire to prolong the firm's life due to higher sunk costs is referred as the "sunk cost effect" the literature. The model thus points to the first effect being more significant than the second. The coefficient on PPs, when compared to SPs, indicates that the total assets figure is a larger (and more significant) contributor to PPs' failure rates-PPs' total assets are on average larger than service providers.

My results confirmed previous findings ${ }^{62}$, specifically the significant positive relationship existing between a firm's size and its survival. A marginal employee increases SPs' survival

\footnotetext{
${ }^{61}$ In their paper, Arkes and Ayton (1999) attribute this attitude to the "no waste" attitude found in human Psychology.

${ }^{62}$ The empirical literature has been more developed on the subject with papers such as Dunne et al. (1989); Mitchell (1994), Audretsch and Mahmood (1994), Haverman (1995), Geroski et al. (2010) Huynh et al. (2008). Theoretically, on the other hand, size effects on growth and survival is harder to find. Jonavovic (1982), a reference, assumes that initial size does not matter and current size includes all the information on the firm history allowing survival or exit. This is contrary to some of the empirical findings cited above reporting the importance of initial size for survival.
} 
probability by 9.6 percent $(\exp (-0.101)=0.9039)$ and increases PPs' survival probability by 11.3 percent $(\exp (-0.120)=0.8869)$. Therefore, the marginal contribution of one employee is larger for product providers ${ }^{63}$. The size effect is stronger on product providers than service providers. Product providers clearly have an advantage in this dimension, and Table 2.6 confirms that PPs are on average larger. Thus, $H 6$ is also confirmed. Although this is an interesting finding, neither the fourth nor the fifth models explain SPs' greater likelihood of survival compared to product providers.

Overall, in the sixth model, both $H 1$ and $H 2$ are rejected, while $H 3, H 5$ and $H 6$ are supported. The sign on the industry wage's coefficient does seem to confirm $H 3$, although the coefficient is insignificant. Thus, I can neither confirm nor reject the hypothesis 3 . The coefficient on PP remains significant, and therefore none of the hypotheses was able to explain PPs' higher failure probability.

- Other possible explanations.

A lack of data did not permit me to test two additional hypotheses that could contribute to the higher survival rate of service providers over product providers. The first one is tax evasion, not to be mistaken with tax avoidance. On the one hand, tax avoidance consists of finding ways not to pay taxes through legal means. Tax evasion, on the other hand, consists of using illegal means to avoid them. Tax evasion comes in many forms, and inspiration does not seem to be in short supply when it comes to finding new ways to escape reporting sales. Some businesses practice tax evasion to retain higher revenues, while others cannot report their sales to authorities because of the illegal nature of their activities. This kind of evasion gave birth to what is now referred to as the shadow, black or underground economy. Slemrod (2007) explains that the underground economy mostly involves the provision of services that are not necessarily illegal

\footnotetext{
${ }^{63}$ This is what we would expect. Size should have a larger effect of PPs than SPs.
} 
but become illicit owing to tax evasion. Davis and Henrekson (2005) claim that the underground economy seems to flourish as tax levels rise. This is the effect of a supply decrease in the labor market, and increases in home labor and the underground market. Fichtenbaum (1989) argues that the underground economy is mostly composed of small businesses that offer services because of the ease of exchanging them for cash or other services. Hence, the literature seems to agree that SPs are more likely to evade taxes, allowing them to increase revenues and profits. Assuming that higher revenues - ceteris paribus - increase survival probability, then, by transitive property, SPs are more likely to survive.

Table 2.8

Regressions Stacking Variables

\begin{tabular}{|c|c|c|c|c|c|c|c|}
\hline Variables & Base Model & Model 1 & Model 2 & Model 3 & Model 4 & Model 5 & Model 6 \\
\hline$\overline{\mathrm{PP}}$ & $0.304^{* * *}$ & $0.341 * * *$ & $0.326^{* * *}$ & $0.297 * *$ & $0.297 * *$ & $0.251^{* *}$ & $0.324^{* *}$ \\
\hline & $(0.105)$ & $(0.117)$ & $(0.117)$ & $(0.119)$ & $(0.119)$ & $(0.122)$ & $(0.157)$ \\
\hline PB & $\begin{array}{l}-0.128^{*} \\
(0.0774)\end{array}$ & $\begin{array}{c}-0.107 \\
(0.0843)\end{array}$ & $\begin{array}{c}-0.0975 \\
(0.0843)\end{array}$ & $\begin{array}{c}-0.109 \\
(0.0856)\end{array}$ & $\begin{array}{c}-0.109 \\
(0.0855)\end{array}$ & $\begin{array}{c}-0.0976 \\
(0.0865)\end{array}$ & $\begin{array}{c}-0.247 * * \\
(0.115)\end{array}$ \\
\hline $\begin{array}{l}\text { SP capital } \\
\text { per worker }\end{array}$ & & $\begin{array}{c}-0.0799 \\
(0.0510)\end{array}$ & $\begin{array}{c}-0.0599 \\
(0.0505)\end{array}$ & $\begin{array}{c}-0.0700 \\
(0.0535)\end{array}$ & $\begin{array}{c}-0.0706 \\
(0.0536)\end{array}$ & $\begin{array}{c}0.0711 \\
(0.0583)\end{array}$ & $\begin{array}{l}-0.0916 \\
(0.0827)\end{array}$ \\
\hline PP capital & & $-0.228 * *$ & $-0.190^{*}$ & $-0.179^{*}$ & $-0.179^{*}$ & -0.128 & $-0.419 * * *$ \\
\hline per worker & & $(0.111)$ & $(0.102)$ & $(0.101)$ & $(0.102)$ & $(0.0833)$ & $(0.111)$ \\
\hline PB capital & & -0.0746 & -0.0502 & -0.0550 & -0.0557 & 0.0745 & 0.0174 \\
\hline per worker & & $(0.0621)$ & $(0.0610)$ & $(0.0638)$ & $(0.0639)$ & $(0.0641)$ & $(0.0773)$ \\
\hline Expenses & & & $-0.0159 * * *$ & $-0.0177 * * *$ & $-0.0177 * * *$ & $-0.0174 * * *$ & $-0.0172 * * *$ \\
\hline per worker & & & $(0.00503)$ & $(0.00531)$ & $(0.00532)$ & $(0.00504)$ & $(0.00475)$ \\
\hline Owners' & & & & $-0.0156 * * *$ & $-0.0157 * * *$ & $-0.0149 * * *$ & $-0.0142 * * *$ \\
\hline experience & & & & $(0.00396)$ & $(0.00396)$ & $(0.00396)$ & $(0.00390)$ \\
\hline Industry & & & & & -0.153 & -0.163 & -0.167 \\
\hline wage & & & & & (0.104) & $(0.103)$ & $(0.104)$ \\
\hline SP assets & & & & & & $\begin{array}{c}-0.0951 * * * \\
(0.0352)\end{array}$ & $\begin{array}{c}0.000714 \\
(0.0404)\end{array}$ \\
\hline PP assets & & & & & & $\begin{array}{l}-0.0237 \\
(0.0299)\end{array}$ & $\begin{array}{c}0.112 * * * \\
(0.0408)\end{array}$ \\
\hline PB assets & & & & & & $\begin{array}{c}-0.0861 * * \\
(0.0337)\end{array}$ & $\begin{array}{l}-0.0526 \\
(0.0382)\end{array}$ \\
\hline SP size & & & & & & & $\begin{array}{c}-0.101 * * * \\
(0.0254)\end{array}$ \\
\hline PP size & & & & & & & $\begin{array}{c}-0.120^{* * *} \\
(0.0401)\end{array}$ \\
\hline PB size & & & & & & & $\begin{array}{l}-0.0314 * \\
(0.0174)\end{array}$ \\
\hline Observations & 14,881 & 13,887 & 13,744 & 13,344 & 13,336 & 13,336 & 13,336 \\
\hline
\end{tabular}

Robust standard errors in parentheses; ${ }^{* * *} \mathrm{p}<0.01,{ }^{* *} \mathrm{p}<0.05,{ }^{*} \mathrm{p}<0.1$ 
The second argument I could not study empirically gets its origins from the relationship marketing (RM) literature. The RM scholars agree that the relationship between a firm and its customers is essential for the firm's survival ${ }^{64}$. It seems that SPs are more likely to engage in social human bonds with their customers that will endure for the duration of the relationship (Gronroos, 1990; Czepiel, 1990; Iacobucci, 1994). Bendapudi and Berry (1997) cite three main reasons why customers are more likely to engage in long-term relations with service providers. First, many services — by definition — require customers to commit to long-term relationships by locking them into contracts ${ }^{65}$. Cable provision, insurance, education and extended warranties, are just few examples of service providers locking their customers into long term contracts. Second, hiring an SP without committing to a long-term contract still requires a risk analysis that entails asymmetric information $^{66}$ in the relationship, representing a cost. Changing SPs on a regular basis necessitates new risk analyses, and hence new costs. Retaining the same SPs minimizes cost. For instance, when a person finds a hairdresser that provides her/him with satisfactory results, it is very unlikely she/he will seek out a new hairdresser. Finally, a customer is more likely to establish a relationship with an organization through its employees than through its products ${ }^{67}$. Thus, this human aspect associated with SPs (but defaulting in PPs) should be positively linked to survival.

- Some words about providers of both (PB) service(s) and product(s).

Although this paper does not intend to study PBs, I give the reader an overview of the literature as well as the results found in the analysis. The data show a trend of firms shifting their

\footnotetext{
${ }^{64}$ See Bendapudi and Berry (1997).

${ }^{65}$ This argument was studied in Lovelock (1983).

${ }^{66}$ From Bendapudi and Berry (1997): “...customers may seek on-going relationships with service providers to reduce the perceived risk in evaluating services characterized by intangibility and credence properties."

${ }^{67}$ See Berry (1995).
} 
interests from PPs and SPs to PBs (refer to the data section and Table 2.4). Theoretically, it makes sense for firms to become providers of both.

They get the benefits of selling a product and attracting customers that need to visualize what they are paying for. At the same time, they can secure those customers into contracts that extend for a long period of time. According to Agrawal, Cohen and Zheng (1997) manufacturers are maximizing service quality with enormous markups on service parts in order to maximize service revenue through maintenance contracts after short warranty periods before feeling comfortable letting the customer seek maintenance via independent service providers. Cohen and Whang (1997), by means of a game-strategic set up, studied the difference between a manufacturer and an independent service provider that results from the differentiation in service quality and price. Among their findings, they argue that a large portion of a manufacturer's revenue was derived from the service business offered to their customers. Empirically, I can only make the comparison of PBs to SPs, given PBs and PPs, both in the regressions with SPs acting as missing variable. Referring to both Tables 2.7 and 2.8 , we established that any hypothesis alone — and/or together with other hypotheses — is enough to explain the higher odd of survival of providers of both over service providers. The significance on PB vanishes when any variable is added to the regression.

\subsection{Conclusion}

This study hopefully contributes positively to the literature by looking at firms' survival from a new perspective. I showed that once the contributors to survival were allowed to act differently, when firms are differentiated in the product-service spectrum, new results could be found increasing our knowledge on firms' survival.

Using the KFS as the main dataset, I studied the consequences of the choice firms make on being PPs or SPs on survival. I also included the option to be a PB although this was not the main purpose of this study. I might need to compare PBs to both SPs and PPs in order to see how 
beneficial it could be to firms' survival. When the decision to enter in one part of the "productservice spectrum" is taken, firms could benefit themselves from the general behavior of other similar firms. For instance, on average, we see that product providers are larger, they have more assets, more capital per worker and more expenses when compared to service providers. On the other hand, SPs are more experienced than PPs and additionally they pay higher wages ${ }^{68}$.

Employing a Cox proportional hazard model, I found that the base model does confirm service providers' higher survival probability as compared to product providers. The behaviors associated with the decision to be a PP or an SP were tested to find whether one, or a combination of them, could explain the reasons for the higher survival probability found for service providers over product providers. Unfortunately, none of the stated hypotheses (capital per worker, expenses per worker, owners' experience, size, assets and industry wage) could bring the coefficient on PP to be insignificant, and all those variables were rejected as possible explanatory factors in SPs higher survival likelihood. Two other possible explanations were discussed but not tested opening the door to future research. The first one is the higher likelihood for SPs to evade taxes and therefore increase revenue. Fichtenbaum (1989) explains that firms evading taxes (underground economy) are more likely small businesses specializing in providing service(s). The higher probability of evading taxes associated with service providers could explain how SPs are, on average, more likely to survive. The second possible explanation is the human-bonding experiences that service providers enjoy over product providers. Service providers can lock customers into long-term contracts hence insuring repeat business. Other benefits include the cost associated to asymmetric information emerging from the business-customer relationship and the human social interaction SPs are able to offer thanks to the increasing personal knowledge of each individual customer.

\footnotetext{
${ }^{68}$ Service providers have greater values for the variables usually used to proxy experience and quality.
} 
Although this paper has not found (empirically) the reasons for SPs higher survival probability, new findings emerged that offer a better understanding of firms' survival. Capital per worker is a very important contributor to PPs' survival. The results show that an increase of $\$ 100,000$ in capital per worker for PPs will decrease their exit probability by 20.39 percent. The results found on size are contradictory to the literature ${ }^{69}$. I found that PPs seem to benefit from higher positive marginal effect size on survival (PPs are larger on average). Last, but not least, I found that an increase in assets was actually increasing the hazard for PPs, something previous research has not established. Once the positive effect associated with size ${ }^{70}$ is controlled for and when we allow the coefficients on PPs and SPs to be different, I do find a significant coefficient on PPs' assets suggesting that assets in themselves are negatively related to survival.

\footnotetext{
${ }^{69}$ Namely, service industries known to be labor intensive as opposed to product-providing industries that are known to be capital intensive, I expected the firm's number of employees as proxy for size to have a higher positive marginal effect on survival for SPs.

${ }^{70}$ Assets are a good measure of size. I can assume that the more assets a firm owns the larger it is.
} 


\section{REFERENCES}

Abraham, K.G. \& Taylor, S.K., 1996. Firms' use of outside contractors: theory and evidence. Journal of Labor Economics, 14(3), pp.394-424.

Agrawal, V., Cohen, M.A. \& Zhen, Y.-S., 1997. Service parts logistics: a benchmark analysis. IIE Transactions, 29, p.627+.

Arkes, H.R. \& Ayton, P., 1999. The sunk cost and Concorde effects: Are humans less rational than lower animals? Psychological Bulletin, 125(5), pp.591-600.

Åstebro, T. \& Bernhardt, I., 2003. Start-up financing, owner characteristics, and survival. Journal of Economics and Business, 55(4), pp.303-319.

Audretsch, D.B., 1991. New-firm survival and the technological regime. The Review of Economics and Statistics, 73(3), pp.441-450.

Audretsch, D.B. \& Mahmood, T., 1994. The rate of hazard confronting new firms and plants in U.S. manufacturing. Review of Industrial Organization, 9(1), pp.41-56.

Barney, J., 1991. Firm resources and sustained competitive advantage. Journal of Management, 17(1), pp.99 -120.

Baumol, W.J., 1967. Macroeconomics of unbalanced growth: the anatomy of urban crisis. The American Economic Review, 57(3), pp.415-426.

Baumol, W.J., Blackman, S.A.B. \& Wolff, E.N., 1985. Unbalanced growth revisited: asymptotic stagnancy and new evidence. The American Economic Review, 75(4), pp.806-817.

Bendapudi, N. \& Berry, L.L., 1997. Customers' motivations for maintaining relationships with service providers. Journal of Retailing, 73(1), pp.15-37.

Berry, L.L., 1995. On great service: A framework for action., New York: The Free Press.

Bhattacherjee, A., 2001. An empirical analysis of the antecedents of electronic commerce service continuance. Decision Support Systems, 32(2), pp.201-214.

Bolton, R.N., 1998. A dynamic model of the duration of the customer's relationship with a continuous service provider: the role of satisfaction. Marketing Science, 17(1), pp.45-65.

Braymen, C.B. \& Neymotin, F., 2011. Immigrant enclaves and the success of entrepreneurial ventures. Available at: SSRN: http://ssrn.com/abstract=1518929.

Cohen, M.A. \& Whang, S., 1997. Competing in product and service: a product life-cycle model. Management Science, 43(4), pp.535-545.

Cooley, T.F. \& Quadrini, V., 2001. Financial markets and firm dynamics. The American Economic Review, 91(5), pp.1286-1310.

Cox, D.R., 1972. Regression models and life-tables. Journal of the Royal Statistical Society. Series B (Methodological), 34(2), pp.187-220. 
Czepiel, J.A., 1990. Service encounters and service relationships: Implications for research. Journal of Business Research, 20(1), pp.13-21.

Davis, S.J. \& Henrekson, M., 2005. Tax effects on work activity, industry mix and shadow economy size: evidence from rich-country comparisons. R. Gomez Salvador et al., eds. In Labour Supply and Incentives to Work in Europe. Edward Elgar Press.

Dunne, T., Roberts, M.J. \& Samuelson, L., 1989. The growth and failure of U. S. manufacturing plants. The Quarterly Journal of Economics, 104(4), pp.671-698.

Evans, D.S. \& Jovanovic, B., 1989. An estimated model of entrepreneurial choice under liquidity constraints. Journal of Political Economy, 97(4), pp.808-827.

Falvey, R.E. \& Gemmell, N., 1996. Are services income-elastic? Some new evidence. Review of Income and Wealth, 42(3), pp.257-269.

Fazzari, S.M., Hubbard, G.R. \& Petersen., B.C., 1988. Financing constraints and corporate investment. Brookings Papers on Economic Activity, 1, pp.141-195.

Fichtenbaum, R., 1989. The Productivity slowdown and the underground economy. Quarterly Journal of Business and Economics, 28, pp.78-90.

Freund, C. \& Weinhold, D., 2002. The internet and international trade in services. The American Economic Review, 92(2), pp.236-240.

Geroski, P.A., Mata, J. \& Portugal, P., 2010. Founding conditions and the survival of new firms. Strategic Management Journal, 31(5), pp.510-529.

Gordon, R.H., 1998. Can high personal tax rates encourage entrepreneurial activity? IMF Staff Papers, 45(1), pp.49-80.

Gronroos, C., 1990. Relationship approach to marketing in service contexts: The marketing and organizational behavior interface. Journal of Business Research, 20(1), pp.3-11.

Hall, B.H., 1987. The Relationship between firm size and firm growth in the US manufacturing sector. The Journal of Industrial Economics, 35(4), pp.583-606.

Haveman, H.A., 1995. The demographic metabolism of organizations: industry dynamics, turnover, and tenure distributions. Administrative Science Quarterly, 40(4), pp.586-618.

Huyhebaert, N., Gaeremynck, A. \& Van de Gucht, L. M., 2000. New firm survival: the effects of start-up characteristics. Journal of Business Finance \& Accounting, 27(5-6), pp.627-651.

Huynh, K.P., Petrunia, R.J. \& Voia, M.C., 2010. The impact of initial financial state on firm duration across entry cohorts.The Journal of Industrial Economics, 58(3), pp.661-689.

Huynh, K.P., Petrunia, R.J. \& Voia, M.C., 2008. Startup financial conditions and survival of new firms. In DRUID 25th Celebration Conference 2008. Copenhagen.

Iacobucci, D., 1994. Toward Defining Relationship Marketing. In Relationship Marketing: Theory, methods and applications proceedings of the 1994 Research Conference. Center for Relationship Marketing, Emory University, Atlanta, pp. 89-97. 
Jovanovic, B., 1982. Selection and the evolution of industry. Econometrica, 50(3), pp.649-670.

Kalleberg, A.L. \& Leicht, K.T., 1991. Gender and organizational performance: determinants of small business survival and success. The Academy of Management Journal, 34(1), pp.136-161.

Kennickell, A.B., 1998. List sample design for the 1998 Survey of Consumer Finances. Board of Governors of the Federal Reserve System.

Kennickell, A.B., 1999. Multiple imputation and disclosure protection: The case of the 1995 survey of consumer finances. Luxembourg: Office for Official Publications of the European Communities, pp.381-400.

Klepper, S. \& Simons, K.L., 2000. The making of an oligopoly: firm survival and technological change in the evolution of the U.S. tire industry. Journal of Political Economy, 108(4), pp.728-760.

Lovelock, C.H., 1983. Classifying services to gain strategic marketing insights. The Journal of Marketing, 47(3), pp.9-20.

Lucas, R.E., 1978. On the size distribution of business firms. The Bell Journal of Economics, 9(2), pp.508-523.

Mata, J. \& Portugal, P., 1994. Life duration of new firms. The Journal of Industrial Economics, 42(3), pp.227-245.

Mitchell, W., 1994. The dynamics of evolving markets: the effects of business sales and age on dissolutions and divestitures. Administrative Science Quarterly, 39(4), pp.575-602.

Murray, M.N., 1997. Would tax evasion and tax avoidance undermine national retail sales tax? National Tax Journal, 50(1), pp.167-182.

Oppenheimer, V., 1970. The female labor force in the United States; demographic and economic factors concerning its growth and changing composition. Population Monograph Series, No. 5., Publications Office, Institute of International Studies, 2538 Channing Way, Room 215, Berkeley, California 94720.

Priest, G.L., 2007. A theory of the consumer product warranty. In Economic Analysis of the Law. Blackwell Publishing Ltd, pp. 111-121.

Raa, T.T. \& Wolff, E., 2001. Outsourcing of services and the productivity recovery in U.S. manufacturing in the 1980s and 1990s. Journal of Productivity Analysis, 16(2), p.149.

Robb, A. \& Coleman, S., 2009. The impact of financial capital on business performance: a comparison of women- and men-owned firms. Available at: http://ssrn.com/paper=1400742.

Robb, A., Ballou, J., DesRoches, D., Potter, F., Zhao, Z. \& Reedy, E.J., 2010. An overview of the Kauffman Firm Survey. Kauffman Foundation.

Shane, S., 2008. The illusions of entrepreneurship: The costly myths that entrepreneurs, investors, and policy makers live by, New Heaven: Yale University Press. 
Sharma, A. \& Kesner, I.F., 1996. Diversifying Entry: Some ex ante explanations for postentry survival and growth. The Academy of Management Journal, 39(3), pp.635-677.

Slemrod, J., 2007. Cheating ourselves: The economics of tax evasion. The Journal of Economic Perspectives, 21(1), pp.25-48.

Thompson, P., 2005. Selection and firm survival: Evidence from the Shipbuilding Industry, 18251914. The Review of Economics and Statistics, 87(1), pp.26-36.

Watson, J., 2003. Failure rates for female-controlled businesses: are they any different? Journal of Small Business Management, 41, pp.262-277.

Wernerfelt, B., 1984. A resource-based view of the firm. Strategic Management Journal, 5(2), pp.171-180.

Youndt, M.A., Snell, S.A., Dean, J.W. \& Lepak, D.P., 1996. Human resource management, manufacturing strategy, and firm performance. The Academy of Management Journal, 39(4), pp.836-866.

Zingales, L., 1998. Survival of the fittest or the fattest? Exit and financing in the trucking industry. The Journal of Finance, 53(3), pp.905-938. 


\section{CHAPTER 3}

\section{Why are Women-Owned Firms Associated with Higher Failure Rates? A Cross Gender Survival Analysis using the KFS.}

\subsection{Introduction}

Previous research has extensively covered the field of survival and gender differences in business settings. Surprisingly, given the amount of studies published, researchers still have many disagreements about the mechanism at work in determining the effects of being women-owned on a startup's (or firm's) survival. More precisely, a majority of studies have found women to have higher failure rates than their men counterparts, but much of this effect may be explained by human capital, industries (Watson 2003), financial capital (Boden and Nucci 2000) or management style (Carter, Williams, and Reynolds 1997). Others, such as Kalleberg and Leicht (1991), have found no negative effects of gender on survival. These opposing results could be attributed to different factors. First, the definition of failure in the literature ${ }^{71}$ varies from broad to specific. For example, some scholars have defined failure as discontinuation ${ }^{72}$ of the firm, including a change of ownership ${ }^{73}$, while others believe that a firm sold does not constitute failure. Another possibility for the lack of consistent results could be the lack of data on womenowned firms.

While comparing women- and men-owned firms' success or failure, social and/or psychological aspects could be at play. The fact that women and men have had differing pasts in the labor market could influence the way they manage or their perception of success. Women are less preoccupied with profits than men (Burns, Carter, Hamilton and Rosa 1994). Therefore, if a man does not get a financial return greater or equal to what he would have made as an employee,

\footnotetext{
${ }^{71}$ Headd (2003) studies the differences in the definitions of success and failure.

${ }^{72}$ Bates (1995); Bates and Nucci (1989); Dunne, Roberts and Samuelson (1989) define failure as discontinuance.

${ }^{73}$ Churchill (1952); Watson and Everett (1999).
} 
even if the firm is still profitable, he would most likely close, and the firm would be registered as a failure. On the other hand, a woman who gets a lower financial return from her business, as compared to what she could have made in the labor market, could choose to keep the company afloat because of the greater flexibility associated with her work schedule, hence reducing failure rates for women. A greater flexibility implies that she can choose when to work and still take care of her home. Thus, there are different maximization problems associated with gender when the decision to remain or exit is made. Furthermore, women and men differ in their evaluation of priorities (Orban 2001).

Firm survival analysis has also been conducted using many economic variables, which are mostly endogenous of social differences, such as accumulated human capital. Historically, women have had less access to education, although the gap is now closing. The actual cross gender differences in education are mostly attributed to the field of education sought by women and men (Honing-Haftel and Martin 1986). Women are more prone to follow liberal arts majors, while men seem to be attracted to technical fields, such as business. Boden and Nucci (2000) hypothesize that the differences among genders that impose a higher burden on women-owned firms' survival could be explained by the lower opportunities offered to women in the wage market. According to Boden and Nucci, answers to financial capital and experience differences can be explained by the lower wages offered to women on average and the lower managerial jobs women partake in. Others have used differences in industry concentrations to explain that women are more active in the retail and services industries, which are more competitive because they are associated with lower barriers of entry (Watson 2003; Coleman and Robb 2009).

Linking both social and labor market experiences, Carter, et al. (1997) suggest that women can use what the authors refer to as "women dispositional characteristics" to overcome deficiencies induced by their "situational differences." Situational differences result from the reality that women have been denied equal access to labor markets, while dispositional 
characteristics are linked to the way women define their values and way of thinking (psychological aspect).

A recurring idea in the literature relates women's lower survival rates to women's lower abilities or opportunities (depending if you view it from the demand or supply side) for them to gather enough financial capital for their startup to grow and survive. It is true that women tend to reach to debt institutions and equity holders less than men. Using the Kauffman Firm Survey (KFS), Coleman and Robb (2009) studied differences in startup capital by gender. Coleman and Robb find that women-owned startups tend to start with significantly less capital than those started by men, and their results remain significant regardless of the addition of controls such as firm's and owner's characteristics. Their contribution to the field was that women tend to raise less capital through debt and equity in the years after foundation (second and third). Considering this, it would be appealing to state that the inability to raise funds must be the reason behind women's lower survival rates in entrepreneurship. Lee and Zhang studied survival associated with financial variables. They find that breaking down debt and equity into different sources was necessary to find the real effects of financial variables. Women have long complained of discrimination in the financial markets (Coleman and Robb 2009). Other papers have dismissed any sign of discrimination in the financial markets and have attributed the differences in access to financial capital to differences in human capital or the industry being operated. Thus, a review of the literature provides the main points as to why women are associated with higher failure rates, but it is difficult to say with certainty which economic variable explains this behavior.

Most of the studies conducted on gender firms' survival were conducted (as far as I know) on dated data sources. Therefore, the release of the Kauffman Firm Survey (KFS), a current longitudinal data set, motivated this paper. Social differences could be an explanation for the higher rates of failure among women-owned firms, and social gaps between genders seem to be diminishing as time passes (women are becoming a more significant part of the labor and 
entrepreneurship market). For these reasons, I believe that the effects of social differences could be diminished in newer data sets. I also have found the empirical methodology in the literature to be inconsistent. Namely, some papers ${ }^{74}$ only use a gender dummy variable in the study. Others papers ${ }^{75}$ are content to compare women-owned firms' survival to those owned by men by dividing the data sets and comparing coefficients. Finally, some papers ${ }^{76}$ have used interaction variables. I will make use of the data at my disposal to find whether economic factors can explain failure rate differences between genders. A proxy for owner's confidence (combining the sociological and psychological) is added as well.

My study will make use of two empirical methods to conduct a more complete survival analysis. I first compare the hazard rates of the firms by using a Cox model. The first empirical method allows me to analyze each variable effect within each subsample and determine whether there are different marginal effects associated with each subgroup. I find that size has a larger negative marginal effect on women-owned firms' failure. Taking into account that women's management styles more often consider employees' satisfaction ${ }^{77}$ to be important, that satisfaction motivates employees, and assuming that employees' satisfaction increases the marginal product of labor, the results seem reasonable. The first empirical method used for the survival analysis also reveals that confidence in holding a competitive advantage is more beneficial to the survival of firms owned by men.

The second empirical model allows interactive gender variables to be added. I ran consecutive regressions after stacking variables, along with their interactive pairs. Only when the competitive advantage variable is added does the gender variable become insignificant. The

\footnotetext{
${ }^{74}$ Bates (1995).

${ }^{75}$ Boden and Nucci (2000).

${ }^{76}$ Carter, et al (1997).

${ }^{77}$ Sheppard (1992).
} 
model's results point out that differences in social and psychological variables play an important role in explaining women-owned firms' higher failure rates. Overall, the full model is unable to fully explain why women-owned firms are associated with higher failure rates.

The paper is organized as follows: I first provide the reader with a review of the literature on how gender differences affect firms' survival. This review will concentrate mostly, but not exclusively, on the variables I use herein. I then give a brief overview of the KFS and provide some descriptive analyses for some of the variables. The third section provides the empirical models and corresponding results. The first model is the gender comparison survival analysis, which precedes the main survival analysis with successive regressions that clarifies womenowned firms' higher chances of failure. Finally, I conclude the paper with a review of the findings and suggestions for future research.

\subsection{The Literature Review}

The literature on firms' success or the survival prospects of firms is extensive. However, only a small part of it is dedicated to gender differences. As society evolves, it has become more evident that there was a need for more research as women started to gain strength in the business environment. Women, as entrepreneurs, have been a growing part of the new creators of small businesses in America, although men are still more likely to be self-employed (Kalleberg and Leicht 1991). Therefore, it is important to understand what factors influence women for business success and survival. There is research that has concentrated on studying women-owned businesses' performance in terms of growth, revenue, profit, and other business success measures. This branch has reported that women-owned firms tend to perform worse than men-owned businesses (Aldrich 1989; Cuba, DeCenzo, and Anish 1983; Du Rietz and Henrekson 2000; Anna, Chandler, Jansen and Mero 1999). Another branch concentrated on survival. Nevertheless, there is an important link between both branches of the literature given that one is a consequence of the other. 
It is reasonable to assume that a business fails because of its performance ${ }^{78}$. Therefore, most of the variables studied in either branch are often found in the other branch of the literature. There are few agreements among researchers. To be more accurate, there is little we can assert with confidence. After considering the reasons that could explain this lack of harmony among studies, I first describe what we know, or what we agree most upon, before discussing the different theories that explain the differences in survival rates between women-owned and menowned businesses.

Carter, et al. (1997) assert that the lack of empirical findings that would corroborate each other had been attributed to "inadequate research design" and "varying assumptions" by researchers. For example the definition of failure is still not agreed upon among studies. Some researchers define failure as entrepreneurs not being able to reach the goals they set for their companies at startup $^{79}$. Over-optimism is a well-known characteristic among entrepreneurs (Cassar and Craig 2009). Others have defined failure as a firm's discontinuation or the business being sold or bankrupt (Watson and Everett 1993).

Among the previous studies there seems to be an agreement among researchers on a higher failure rate experienced by women-owned businesses. Most research found that womenowned businesses are more likely to fail.

Bates (1995) studied the survival rates of newly started firms and franchises in the retail industry using the 1987 Characteristics of Business Owners dataset. Bates (1995) confirmed that firms owned by men were more likely to survive. Some studies were not able to find reasons for the higher likelihood of failure of women-owned firms. Kalleberg and Leicht's (1991) coefficient for gender was insignificant within the general sample regression. This finding was echoed in Lee

\footnotetext{
${ }^{78}$ Although Headd (2003) indicated that some of the businesses reported as having failed (closed) were successful at closure. Headd believed these are not failures.

${ }^{79}$ Headd (2003).
} 
and Zhang's working paper. Cooper, Gimeno-Gascon and Woo (1994) found that women-owned firms were just as likely to survive, but were less likely to grow than men-owned firms.

Many researchers have investigated women's higher business failure rate by analyzing differences between men and women. For instance, Watson (2003) controlled for industry because previous research found evidence that women tend to be over-represented in certain specific industries such as retail and service industries. Kalleberg and Leicht (1991) referred to this as the "female ghetto". Brush and Chaganti (1999) affirmed that the retail and service industries tend to be at the bottom of the value chain, which tends to imply lower returns. Their results confirmed previous studies such as Rosa, Carter and Hamilton (1996), which argued that some of the differences between men and women-owned firms lie in the fact that women have a tendency to start businesses in low-return industries. Hutchinson, Hutchinson and Newcomers (1938) noted that industries with lower capital requirements tend to have a higher failure rate because of lower barriers to entry that increase competition (Brüderl, Preisendörfer and Ziegler 1992). Furthermore, the fact that women use less financial capital on average (Coleman and Robb 2009) (the reasons for this are discussed later) completes a formula for increased failure rates. However, it is not known if women have a preference for the industries cited above because of their lower financial capital requirements (Brush and Chaganti, 1999) or whether women prefer these industries because they fit their management styles.

The age of businesses has also been linked to women's higher failure rates. Some have argued that women-owned firms are younger on average than men-owned firms and that, because younger firms are more likely to fail (Evans 1987), age could thus be a variable negatively linked to women-owned firms' survival ability (Rosa, et al. 1996; Carter, et al. 1997).

The survival literature has consistently agreed that a firm's size is an important contributor to survival (Mata and Portugal 1994; Geroski, et al. 2010). The bigger a firm is at startup, the more it has access to financial markets. Financial institutions may interpret a larger 
firm as reflecting the entrepreneur's confidence in the project and are therefore more likely to invest. Women-owned firms have a tendency to be smaller, on average (Charboneau 1981; Humphreys and McClung 1981; Coleman 2002; Robb and Wolken 2002; Fairlie and Robb 2009). It is hard to say why; the possibilities are numerous. As mentioned previously, it could be because a majority of women start their businesses from home, which puts an upper limit on the number of employees they can hire. It could also be that women have less access to financial markets. Consequently, women have more constraints on liquidity than men, and have a lower capacity for hiring employees ${ }^{80}$, which makes it harder to raise future financial capital.

Another possibility is that women's management style is a better fit for smaller groups. While studying a small sample of women, Sheppard (1992) reported that women portrayed their management style as being based on maintaining good relationships and being people oriented. She affirmed that women have a strong propensity for basing their decision making on personal relations.

Human capital is usually described as the owners' own attributes, acquired through selfinvestment. Easier-to-measure proxies of human capital have often been measures of experience and education. It has been reported that the more specific to an industry previously acquired experience is, the higher the likelihood of survival (Thompson 2005; Van de Ven, Hudson and Schroeder 1984). Theoretically, many factors possibly affecting women-owned firms' higher failure rates could be endogenous results of differences in human capital between men and women. The differences could be at any level of the many spectrums of experience. Running a business as an entrepreneur can be associated with many differing levels of experience, and the question of whether the previous years of experience were acquired in the same or an identical industry has been shown to be deterministic of survival. Taking into account experience acquired

\footnotetext{
${ }^{80}$ Aldrich and Auster (1986) affirm that because of their businesses' smaller size, women have difficulties competing against larger firms for labor, as the latter have a greater ability to pay higher wages and offer better benefits.
} 
while starting a business rather than that of acquiring an older business that has already overcome the challenges of earlier stages of growth is also a major step towards understanding startup survival. Cromie and Birley (1991) reported that women's previous experience was less likely to have been acquired while starting a business. Carter, et al. (1997) found, however, that men seemed to be using the experience acquired from starting previous companies to improve their survival chances. On the other hand, the lack of startup experience for women did not affect survival chances differently. Simply said, women with previous startup experience did not use this advantage to increase survival probability. Boden and Nucci (2000) hypothesize that women, on average, acquire less human capital because of differences in the labor market. Boden and Nucci believe that differences in the labor market (women have historically held lower wage jobs than men) explain why women's accumulated experience and financial capital stock is less than men's.

Education is another measure of human capital that has been widely used in the literature. Honing-Haftel and Martin (1986) report differences among women and men in the areas they seek education in. Women seem to be more attracted to studies in liberal arts, while men are more likely to seek education in technical disciplines ${ }^{81}$. Education in liberal arts is less likely to yield advantages in skills, such as management, finance and development of new technologies, all part of the daily tasks of an entrepreneur. Orban (2001) reported the results of a survey she conducted on women and men in which she asked entrepreneurs to self-evaluate their competencies in different fields. Women who owned firms with employees in the range of 1 to 499, believed themselves to have deficiencies in financial skills. For firms in the range of 10 to 499 employees, women still believed they had lower financial skills than their men counterparts. Men consistently

\footnotetext{
${ }^{81}$ Menzies, Diochon and Gasse (2004) found that women are well educated on average, yet they were less likely to hold degrees in business or technical studies.
} 
evaluated themselves above women's self-evaluations for managerial skills ${ }^{82}$ as well. Interestingly, women in the range of 1 to 499 employees evaluated themselves above men's selfevaluation for technical skills. The question is not really whether women are less educated than men $^{83}$, but rather how do they educate themselves?

Family commitment and the ability to devote enough time to business is an aspect differentiating women and men (Fasci and Valdez 1998). Women have reported challenges in balancing their time between home duties and time to dedicate to their businesses. Assuming that a firm's survival is a positive function of time invested into the business (Boden and Nucci 2000), women-owned firms are therefore more likely to fail (Fasci and Valdez 1998; Birley 1989). Women are attracted to the idea of operating their businesses from home. It allows them to take care of their families and run their businesses. Boden and Nucci (2000) used a dummy variable for home-based businesses on two samples of the Characteristics of Business Owners survey (1982 and 1987). They reported that businesses operating from home were less likely to use financial capital at startup and therefore were less likely to survive. One reason is that homeoperated businesses have an upper limit in size, which in turn could be a negative signal sent to financial institutions that will result in lower financial capital availability.

Among the greatest debate found in the literature is the question of whether or not women are discriminated against in the financial markets (Coleman and Robb 2009). The question was raised because women usually mention that they face some discriminatory treatment when they apply for loans with financial institutions. However, I was not able to find any study that could present results to defend this argument. It is true that women use less capital than men both at startup and in the early stages of a company's life. Coleman and Robb (2009) studied the

\footnotetext{
${ }^{82}$ Hisrich (1985) reported that women lack experience in the financial and managerial fields of business.

${ }^{83}$ Mahot (1997) reported than in the E.U. countries, women's education was equivalent to or even higher than men's.
} 
KFS and found that the women in the sample started their firms with significantly less financial capital than men, and that women also tend to raise less capital in the second and third years of the firm's life. Their results remained significant even after controlling for the usual measures of human capital. However, whether this is an effect of the supply (the financial institutions' selection process) or of the demand side (entrepreneurs' application for financing) of financial markets is harder to say. They found evidence that financial institutions tend to invest more in firms with specific characteristics such as hours spent in the business, prior startup experience and being classified as an organization; these characteristics are not usually associated with women-owned businesses. They also found that women relied more heavily on personal sources of debt and equity, while other research has found women to be more risk averse ${ }^{84}$ than men, leading them to start smaller and more manageable businesses. This would indicate that women themselves are reluctant to apply for external debt and equity. Other papers have indicated that the lower amount of capital raised by women was the results of differences in human capital and the variations could be explained by differences in experience and education between the genders. Tigges and Green (1994) suggested that women's lower levels of experience and lower amounts of equity invested into their businesses might explain women's reduced access to capital markets.

Boden and Nucci's (2000) paper and results are very interesting, as they may show the roots of the financial capital difficulties. Assuming that women's wages in the labor market are actually lower than men's, and that past wages constitute the main source of startup capital, Boden and Nucci found that survival was indeed positively related to startup capital ${ }^{85}$. The negative effects of the demand side consist of women being less likely to apply for loans,

\footnotetext{
${ }^{84}$ Risk aversion has also been presented as a possible contributor to women's higher failure rates. Smaller sizes of business and reduced access to financial markets for investment funds are signs of risk aversity. Therefore other explanatory variables may be endogenous of risk aversity. Several previous studies have suggested that women may be more risk averse (Cliff 1998; Orser and Hogarth-Scott 2002).

${ }^{85}$ They did test for prior managerial experience as well, but have not found it to be statistically significant.
} 
although they are not more likely to be turned down. A couple of studies confirmed demand-side effects on the financial markets (Coleman 2002; Cole and Mehran 2009; Treichel and Scott 2006). This is a puzzle, as women insist on encountering barriers to secure loans in a study by Constantinidis, Cornet and Asandei (2006), yet when the authors separated the firms by growth potential, they found that women with higher growth-potential firms encountered less barriers. I would like to add that the only reference to discrimination in the financial markets I was able to find in the literature was reported mostly by surveys that would describe women's feelings. Women's lower use of financial institutions' services were, usually, the results of other factors that are characteristic of women-owned firms, whether it was human capital, the industry, motivation, or any other factor besides gender. No matter what the causes were, women are more concerned with access to capital than any other problem in managing their businesses (Orser, Hogarth-Scott and Riding, 2000).

Women may be less concerned with financial rewards that men are (Rosa, et al. 1994; Brush 1992), and thus women may pursue a different level of satisfaction when they start a business. Brush (1992) indicated that women thought of their business more as a "cooperative network of relationships" than a "profit-making entity." Nonetheless, Orban (2001) found that women and men classified their motivations more or less in the same order but weighed them differently. For instance, in Orban's sample, independence and self-accomplishment were ranked first in both groups of men and women, but women indicated that prestige attributes, such as social status and power, had a lower value to them as compared to men. These differences in motivation lead to differences in management styles as well. Sheppard (1992) reported that women believed their management style was less cost oriented, with an accent on persuasion and personal relations ${ }^{86}$. My study will not address these latest issues given that the KFS does not

\footnotetext{
${ }^{86}$ This finding was previously reported in Neider (1987).
} 
provide information on management style or preferences. There are other differences reported in the literature ${ }^{87}$, but it is my belief that the ones reported herein provide a good basis for the reader's general understanding of the question.

\subsection{The KFS and Descriptive Statistics}

- $\quad$ The Kauffman Firm Survey (KFS)

The KFS is a random sample of 4,928 businesses taken from an initial pool of 32,429 firms from the Dun and Bradstreet (DB) database created in 2004. The baseline questionnaire was sent in 2004, and follow-up questionnaires were sent every year following that. So far, five following waves consisting of data from 2005, 2006, 2007, 2008, and 2009 have been added to the baseline. The dataset contains information on a variety of topics, including financing, organizational structure and legal status, business characteristics and strategies, owner demographics, and work behavior.

To be part of the KFS sample, a startup could not be a spin-off, a subsidiary of any other business, or inherited by previous owners. The sample weights were adjusted accordingly for surviving firms that chose not to answer.

Some firms surveyed could also be firms created to reduce taxes on individuals. It has been shown in prior research, both theoretical and empirical (Åstebro and Bernhadt 2003; Gordon 1998), that paying fewer taxes could be an incentive for individuals to create companies as tax shelters, because corporate tax rules are often advantageous compared to income taxes. I expect some of the firms surveyed were also created as tax shelters. The way I chose to correct for this issue was to drop the firms that reported no sales in all years of activity (33 observations were deleted).

\footnotetext{
${ }^{87}$ Reese (1992) reported that women had lower levels of social networking.
} 
Table 3.1

Industry Distribution in the KFS

\begin{tabular}{|lccc|}
\hline \multicolumn{1}{|c}{ Industry Names and (Code) } & $\begin{array}{c}\text { KFS New } \\
\text { Employer } \\
\text { Businesses }\end{array}$ & $\begin{array}{c}\text { Census } \\
\text { Employer } \\
\text { Firm Births }\end{array}$ & $\begin{array}{c}\text { PSED New } \\
\text { Businesses }\end{array}$ \\
$\begin{array}{l}\text { Professional (54), Management, } \\
\text { and Educational Services (61) }\end{array}$ & 16.1 & 14.1 & 16.8 \\
Retail Trade (44) & 15.6 & 12.0 & 18.6 \\
Administrative and Support, and Waste & 11.4 & 6.0 & 2.1 \\
Management and Remediation Services (56) & & 15.7 & 10.0 \\
Construction (23) & 9.8 & 8.5 & 0.3 \\
Other Services (except Public Administration) & 8.0 & 3.2 & 3.5 \\
(81) & 7.2 & 4.5 & 1.5 \\
Manufacturing (31) & 6.0 & 5.1 & 5.3 \\
Wholesale Trade (42) & 3.7 & 2.2 & 3.1 \\
Real Estate, Rental and Leasing (53) & 4.7 & 7.7 & 2.9 \\
Finance and Insurance (52) & 4.2 & 1.4 & 4.2 \\
Health Care and Social Assistance (62) & 2.6 & 3.3 & 2.4 \\
Information (51) & 2.9 & 2.1 & 3.2 \\
Transportation and Warehousing (48) & 3.1 & 9.1 & 10.9 \\
Arts, Entertainment, and Recreation (71) & 3.9 & 0.4 & 2.0 \\
Accommodation and Food Services (72) & 1.4 & 0.3 & 0.5 \\
Agriculture, Forestry, Fishing, and hunting (11) & 0.0 & 0.1 & 0.5 \\
Mining (21) & 0.0 & 6.7 \\
Utilities (22) & 0.0 & 5.6 \\
Management of Companies and Enterprises (55) & & & \\
Unclassified (99) & & & \\
\hline
\end{tabular}

Source: Kauffman Firm Survey, Baseline data: Tabulations by Mathematica Policy Research, Inc; and Office of Advocacy, U.S. Small Business Administration, from longitudinal data (established with some first-quarter payroll) provided by the U.S. Census Bureau; Reynolds, P. 2004. Entrepreneurship in the United States Assesment, Miami, Fla: Florida International University.

Finally, it is worth mentioning that as compared to the U.S. Census, the distribution of firms by industry in the KFS has higher proportions of businesses in certain industries ${ }^{88}$, such as manufacturing, professional management, education, retail and wholesale, and finance and

\footnotetext{
${ }^{88}$ The oversampled industries are the ones most favored by women.
} 
insurance, just to cite a few. However, the KFS has a lower proportion of firms in construction, healthcare and social assistance, and accommodations and food services (see Table 3.1).

- Descriptive statistics

An objective of the paper is to first check if women-owned firms are indeed more likely to fail in the KFS, considering its novelty.

Each firm in the sample can describe 10 of its owners. If a firm has more than one owner, the KFS declares the owner with the most equity invested in the firm to be the main owner. In case of equal ownership, the KFS uses the number of hours worked and other characteristics to determine the main owner. Therefore, if a firm's main owner was found to be a woman, this firm is classified as women-owned. 26 percent of firms were women-owned at startup in 2004. This percentage decreases every year, among surviving firms, before reaching 15 percent in 2009 (see Table 3.2). As mentioned in the literature review, studies use different definitions of failure. I define discontinuance at time $\mathrm{t}$ as a firm that was active in the lagged period, $\mathrm{t}-1$, and if the firm has stopped operations temporarily (and does not reappear in any other period) or has declared to be permanently out of business, or has declared to be out of business for any other reason besides a change in ownership.

As demonstrated by the Nelson-Aalen cumulative hazard graph (see Figure 3.1), women do have a higher likelihood of failure. Looking at the Nelson-Aalen graph, we see the difference between the men-owned and women-owned curves is increasing in every period. This is an indication that the difference in failure rates is increasing every year. 
Table 3.2

Summary Statistics for the Whole Sample

\begin{tabular}{|c|c|c|c|c|c|c|}
\hline & \multicolumn{2}{|c|}{2004} & \multicolumn{2}{|c|}{2005} & \multicolumn{2}{|c|}{2006} \\
\hline Variables & Mean & Sd & Mean & Sd & Mean & Sd \\
\hline Gender & 0.26 & 0.44 & 0.22 & 0.41 & 0.19 & 0.39 \\
\hline Size & 3.12 & 4.11 & 4.25 & 5.28 & 4.6 & 5.68 \\
\hline Main owner experience & 12.69 & 10.5 & 13.03 & 10.58 & 13.36 & 10.61 \\
\hline Mean experience & 12.29 & 9.84 & 12.62 & 9.94 & 12.74 & 9.88 \\
\hline Home Operation & 0.5 & 0.5 & 0.42 & 0.49 & 0.38 & 0.49 \\
\hline Competitive advantage & 0.64 & 0.48 & 0.58 & 0.49 & 0.51 & 0.5 \\
\hline Total debt & 73,144 & 189,792 & 54,757 & 163,264 & 54,480 & 162,613 \\
\hline Total equity & 59,874 & 165,486 & 36,833 & 138,635 & 25,705 & 116,443 \\
\hline Total equity OO & 57,076 & 151,332 & 24,170 & 99,967 & 16,687 & 84,872 \\
\hline Total equity NOO & 22,842 & 120,108 & 14,951 & 104,131 & 10,099 & 83,126 \\
\hline \multirow{3}{*}{$\begin{array}{l}\text { Total equity NOO formal } \\
\text { Total equity NOO non- } \\
\text { formal }\end{array}$} & 17,145 & 118,930 & 12,775 & 103,911 & 10,073 & 99,029 \\
\hline & 3,931 & 43,806 & 2,514 & 36,290 & 1,332 & 24,637 \\
\hline & \multicolumn{2}{|c|}{2007} & \multicolumn{2}{|c|}{2008} & \multicolumn{2}{|c|}{2009} \\
\hline Variables & Mean & Sd & Mean & Sd & Mean & Sd \\
\hline Gender & 0.17 & 0.38 & 0.16 & 0.37 & 0.15 & 0.36 \\
\hline Size & 4.63 & 6.31 & 4.59 & 6.13 & 4.52 & 6.14 \\
\hline Main owner experience & 13.57 & 10.65 & 13.94 & 10.79 & 14.05 & 10.66 \\
\hline Mean experience & 12.97 & 9.95 & 13.32 & 10.02 & 13.54 & 9.96 \\
\hline Home Operation & 0.34 & 0.47 & 0.34 & 0.47 & 0.33 & 0.47 \\
\hline Competitive advantage & 0.44 & 0.5 & 0.4 & 0.49 & 0.33 & 0.47 \\
\hline Total debt & 46,678 & 150,625 & 50,395 & 161,185 & 44,564 & 152,451 \\
\hline Total equity & 18,520 & 99,995 & 15,847 & 92,713 & 14,962 & 91,706 \\
\hline Total equity OO & 11,827 & 70,444 & 11,468 & 71,519 & 10,232 & 67,345 \\
\hline Total equity NOO & 6,945 & 70,976 & 5,674 & 65,772 & 5,747 & 67,210 \\
\hline Total equity NOO formal & 6,064 & 77,876 & 5,650 & 74,176 & 5,720 & 79,355 \\
\hline formal & 1,345 & 23,359 & 433 & 9,761 & 677 & 16,425 \\
\hline
\end{tabular}

Source: Kauffman Firm Survey, 2011 release.

Table 3.3 shows the summary statistics for both men and women. I calculate the firm size as the total number of employees working for the firm, including the number of operating owners. We can see that women-owned firms are smaller on average than men-owned firms. The difference in size seems to grow as the firms become older-although there is a big dispersion in the distribution as shown by the standard deviations. 
Figure 3.1

Nelson-Aalen Cumulative Hazard Graph

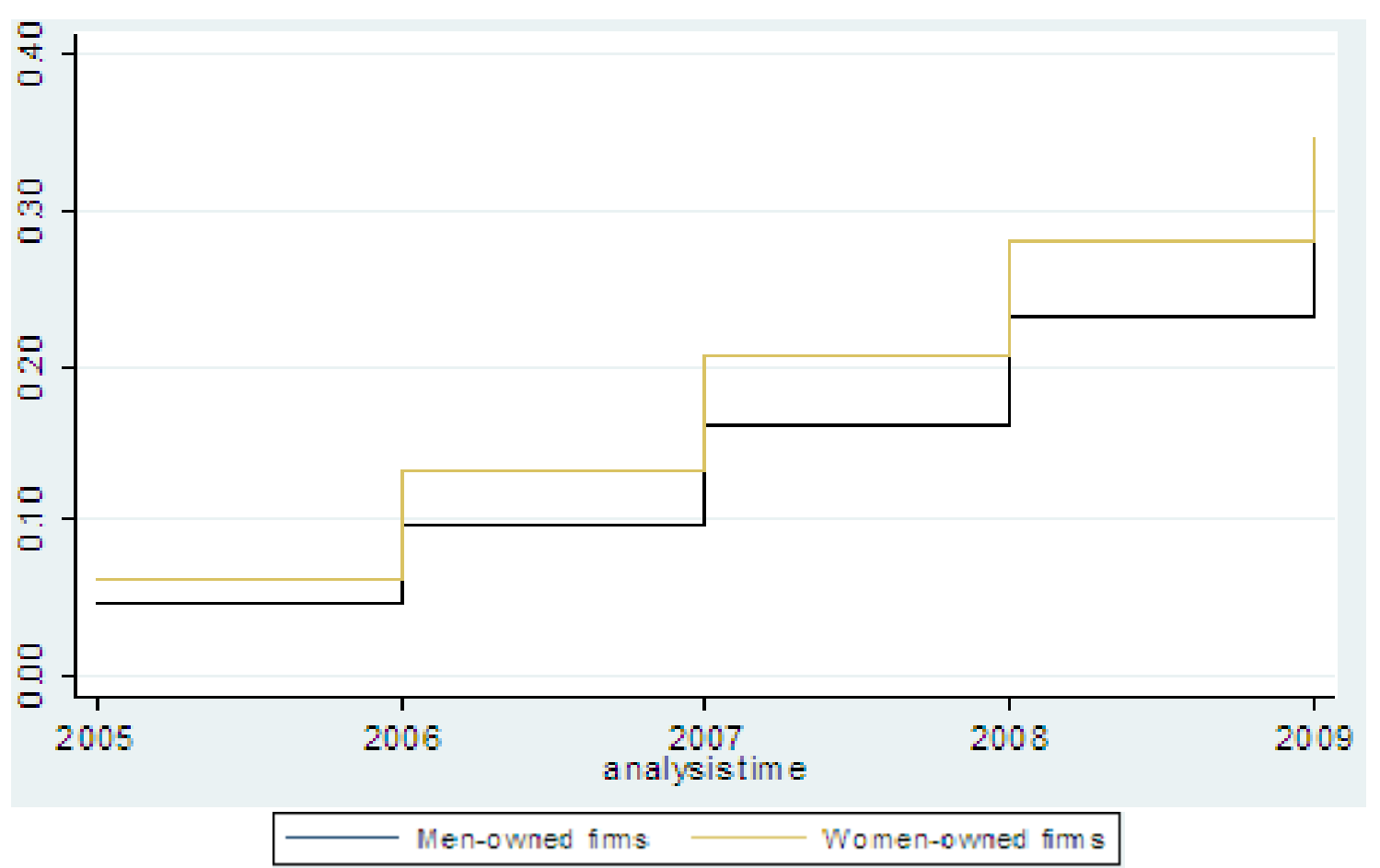

Source: Kauffman Firm Survey, 2011 release.

The owners' experience is defined by the KFS as the years of experience in the same industry the firm competes in $^{89}$. I link a firm's experience to the levels reported by the firm's main owner. It seems that the KFS is no exception to previous findings. Women are, on average, less experienced when compared to men.

I then look at home-operated businesses and whether the owners believe they hold a competitive advantage over their competition. As expected, women are more likely to operate from their homes. What is surprising is that the percentage of women operating from home does not decrease as the firms grow older, although the percentage of men operating from home tends to go down. We would expect firms - regardless of the owner's gender-operating from home to make up a lower part of the sample as firms start exiting (see Figure 3.2). If home-operated

\footnotetext{
${ }^{89}$ This variable is bounded from above at 40 years.
} 
businesses are more likely to exit, then it could be that women tend to move their businesses home later in the life of the business ${ }^{90}$.

Figure 3.2

\section{Home-Operated Businesses Comparison between Women- and Men-Owned Firms}

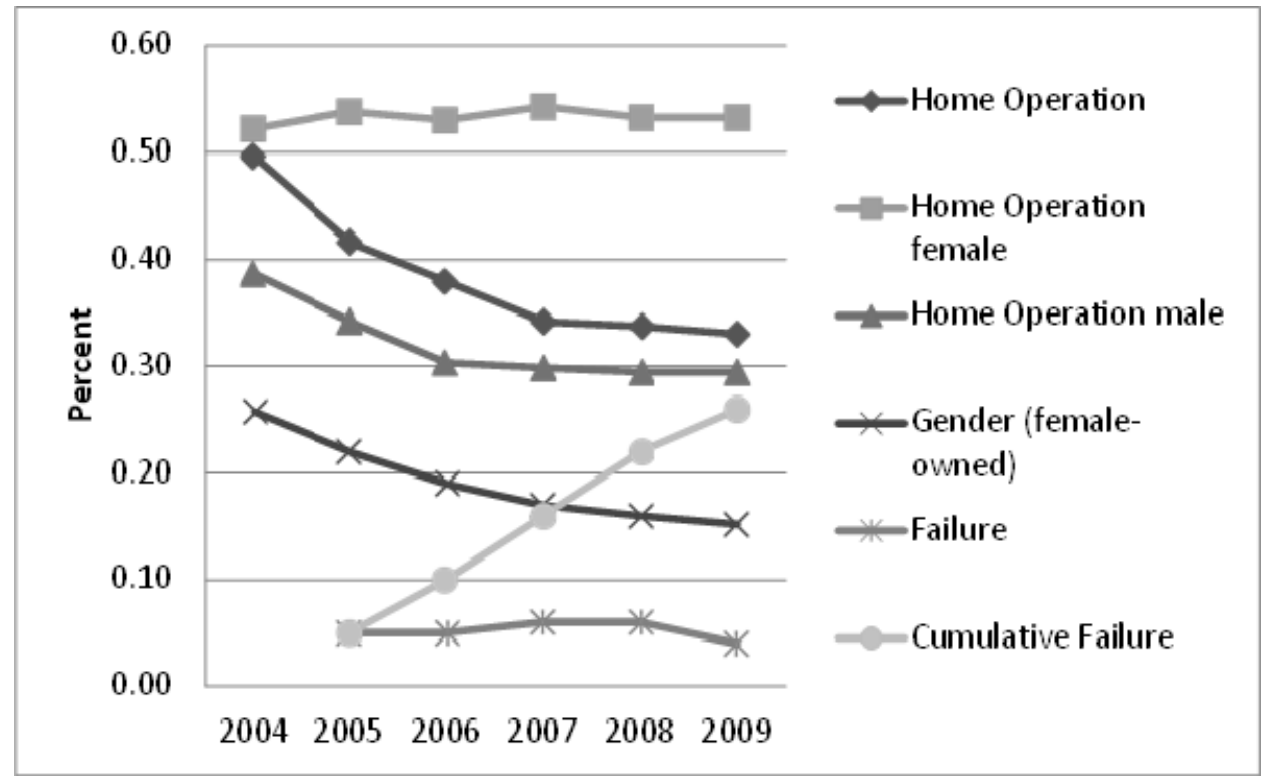

Source: Kauffman Firm Survey, 2011 release.

I use the competitive advantage dummy to proxy for owner's confidence. Given this is a self-reported variable, I assume ${ }^{91}$ that owners do not have a clear idea of their advantage over the competition in the early stages of the firm's life. Therefore, an owner who declares having a competitive advantage could be exhibiting a sign of confidence ${ }^{92}$. Surprisingly, the data suggest that 68 percent of women-owned firms believe they held a competitive advantage at startup compared to only 55 percent of men-owned firms. Overall, women seem to be more confident

\footnotetext{
90 The results for the probit regressions on home-operated businesses can be found in Appendix 3.1. I find that the probability for women to be operating from home increases every year.

${ }^{91}$ Jovanovic (1980) suggested that an entrepreneur's judgment of the venture became clearer as the firm grew older.

${ }^{92}$ Koellinger, Minniti and Schade (2007) found entrepreneurs to be overconfident by analyzing samples in many countries. Forbes (2005) found a negative correlation between overconfidence and survival rates.
} 
than men in their competitive advantage in every year of the firm's existence. There could be three explanations. The first one is that these data reflect the reality that women have a better competitive advantage than men on average. The second possible explanation is that women overvalue their competitive advantage position (optimism), and finally ${ }^{93}$, the third possibility is that men undervalue their competitive advantage (pessimism).

Table 3.2 gives an overview of the financial variables ${ }^{94}$ for the whole sample. Debt seems to be the preferred way to finance the startups when analyzing the whole sample, if we look at the mean, but the standard deviation indicates that there is a big dispersion in the sample distribution.

Actually, all the financial variables shown in Table 3.2 are very dispersed ${ }^{95}$, which is why I calculate the median ${ }^{96}$ of these variables. The medians for total debt and total equity are 751 and 4001, respectively, for 2004 . Therefore, 50 percent of the sample used more equity than debt. The medians for formal and non-formal sources of equity from non-owners/operators were both zero. Therefore, the analysis through the mean can be misrepresenting the data. According to Coleman and Robb (2009), findings on gender financing - using the three first waves of the KFS (2004, 2005, and 2006) - firms owned by men raised more money in the first three years of operations when compared to women-owned firms (US $\$ 200,000$ for men and US $\$ 120,000$ for women). They also found that women use less financial capital to start up their business and raise considerably less financial capital than men in the following years (at least for 2005 and 2006) of operations. Both women and men prefer internal to external sources of funds.

\footnotetext{
${ }^{93}$ Forbes (2005) found an negative correlation between overconfidence and survival rates.

${ }^{94}$ Note that the variables "total debt" (and "total equity") are the total amount of debt (equity) owed by the firm at time t. It is both the amount of outstanding and new debt (equity) the firm used to finance its operations.

${ }^{95}$ The distribution of the financial variables is asymmetrical and positively skewed, as shown by the financial variables' detailed summary statistics in Appendix3.2.

${ }^{96}$ Not shown here.
} 
Table 3.3

Summary Statistics Comparison between Genders

\begin{tabular}{|c|c|c|c|c|c|c|c|c|}
\hline \multirow[b]{3}{*}{ Variables } & \multicolumn{4}{|c|}{2004} & \multicolumn{4}{|c|}{2005} \\
\hline & \multicolumn{2}{|c|}{ Women-owned } & \multicolumn{2}{|c|}{ Men-owned } & \multicolumn{2}{|c|}{ Women-owned } & \multicolumn{2}{|c|}{ Men-owned } \\
\hline & Mean & Sd. & Mean & Sd & Mean & Sd. & Mean & Sd. \\
\hline Size & 3.41 & 4.39 & 4.54 & 5.52 & 3.55 & 4.26 & 4.93 & 6.03 \\
\hline Main owner experience & 9.53 & 9.27 & 14.25 & 10.73 & 9.68 & 9.2 & 14.59 & 10.76 \\
\hline Mean experience & 9.63 & 8.72 & 13.66 & 10.13 & 9.86 & 8.72 & 13.7 & 10.06 \\
\hline Home Operation & 0.52 & 0.5 & 0.39 & 0.49 & 0.54 & 0.5 & 0.34 & 0.47 \\
\hline Competitive advantage & 0.68 & 0.47 & 0.55 & 0.5 & 0.66 & 0.47 & 0.48 & 0.5 \\
\hline Total debt & 42,250 & 138,373 & 58,282 & 169,471 & 47,257 & 145,007 & 56,175 & 166,450 \\
\hline Total equity & 20,452 & 90,600 & 41,449 & 149,094 & 18,802 & 91,654 & 27,326 & 121,486 \\
\hline Total equity $\mathrm{OO}$ & 13,573 & 61,174 & 27,156 & 108,241 & 11,547 & 58,531 & 17,894 & 89,907 \\
\hline Total equity NOO & 6,423 & 63,921 & 17,354 & 112,796 & 6,831 & 65,459 & 10,866 & 86,744 \\
\hline $\begin{array}{l}\text { Total equity NOO } \\
\text { formal }\end{array}$ & 4,404 & 61,559 & 15,134 & 112,911 & 5,493 & 72,470 & 11,148 & 104,267 \\
\hline \multirow[t]{3}{*}{$\begin{array}{l}\text { Total equity NOO non- } \\
\text { formal }\end{array}$} & 2,593 & 34,910 & 2,492 & 36,675 & 1,364 & 19,976 & 1,325 & 25,610 \\
\hline & \multicolumn{4}{|c|}{2006} & \multicolumn{4}{|c|}{2007} \\
\hline & \multicolumn{2}{|c|}{ Women-owned } & \multicolumn{2}{|c|}{ Men-owned } & \multicolumn{2}{|c|}{ Women-owned } & \multicolumn{2}{|c|}{ Men-owned } \\
\hline Variables & Mean & Sd & Mean & Sd & Mean & Sd & Mean & Sd \\
\hline Size & 3.51 & 4.86 & 4.97 & 6.65 & 3.52 & 4.74 & 4.91 & 6.46 \\
\hline Main owner experience & 9.81 & 9.31 & 14.8 & 10.77 & 10.56 & 9.77 & 15.04 & 10.87 \\
\hline Mean experience & 10.16 & 8.83 & 13.91 & 10.13 & 10.73 & 9.11 & 14.2 & 10.17 \\
\hline Home Operation & 0.53 & 0.5 & 0.3 & 0.46 & 0.54 & 0.5 & 0.3 & 0.46 \\
\hline Competitive advantage & 0.61 & 0.49 & 0.4 & 0.49 & 0.59 & 0.49 & 0.36 & 0.48 \\
\hline Total debt & 45,294 & 143,786 & 46,961 & 152,006 & 58,909 & 175,650 & 48,777 & 158,265 \\
\hline Total equity & 15,614 & 83,178 & 19,115 & 103,098 & 13,509 & 80,071 & 16,292 & 94,930 \\
\hline Total equity OO & 9,776 & 52,732 & 12,247 & 73,543 & 9,785 & 61,617 & 11,788 & 73,254 \\
\hline Total equity NOO & 6,034 & 65,247 & 7,132 & 72,100 & 3,278 & 47,021 & 6,129 & 68,756 \\
\hline $\begin{array}{l}\text { Total equity NOO } \\
\text { formal }\end{array}$ & 3,459 & 55,940 & 6,597 & 81,636 & 3,010 & 50,380 & 6,151 & 77,876 \\
\hline $\begin{array}{l}\text { Total equity NOO non- } \\
\text { formal }\end{array}$ & 1,176 & 21,450 & 1,380 & 23,734 & 464 & 5,155 & 427 & 10,409 \\
\hline
\end{tabular}

Source: Kauffman Firm Survey, 2011 release. 
Table 3.3 Continued

\begin{tabular}{|c|c|c|c|c|c|c|c|c|}
\hline \multirow[b]{3}{*}{ Variables } & \multicolumn{4}{|c|}{2008} & \multicolumn{4}{|c|}{2009} \\
\hline & \multicolumn{2}{|c|}{ Women-owned } & \multicolumn{2}{|c|}{ Men-owned } & \multicolumn{2}{|c|}{ Women-owned } & \multicolumn{2}{|c|}{ Men-owned } \\
\hline & Mean & Sd & Mean & Sd & Mean & Sd & Mean & Sd \\
\hline Size & 3.51 & 4.83 & 4.81 & 6.45 & 3.51 & 4.83 & 4.81 & 6.45 \\
\hline Main owner experience & 10.7 & 9.58 & 15.12 & 10.77 & 10.7 & 9.58 & 15.12 & 10.77 \\
\hline Mean experience & 10.97 & 9.02 & 14.36 & 10.11 & 10.97 & 9.02 & 14.36 & 10.11 \\
\hline Home Operation & 0.53 & 0.5 & 0.29 & 0.46 & 0.53 & 0.5 & 0.29 & 0.46 \\
\hline Competitive advantage & 0.48 & 0.5 & 0.31 & 0.46 & 0.48 & 0.5 & 0.31 & 0.46 \\
\hline Total debt & 46,159 & 145,121 & 44,278 & 153,747 & 46,159 & 145,121 & 44,278 & 153,747 \\
\hline Total equity & 11,050 & 74,331 & 15,661 & 94,471 & 11,050 & 74,331 & 15,661 & 94,471 \\
\hline Total equity OO & 6,864 & 42,569 & 10,835 & 70,857 & 6,864 & 42,569 & 10,835 & 70,857 \\
\hline Total equity NOO & 4,443 & 61,421 & 5,980 & 68,201 & 4,443 & 61,421 & 5,980 & 68,201 \\
\hline $\begin{array}{l}\text { Total equity NOO } \\
\text { formal }\end{array}$ & 6,326 & 98,984 & 5,612 & 75,327 & 6,326 & 98,984 & 5,612 & 75,327 \\
\hline $\begin{array}{l}\text { Total equity NOO non- } \\
\text { formal }\end{array}$ & 229 & 2,222 & 757 & 17,808 & 229 & 2,222 & 757 & 17,808 \\
\hline
\end{tabular}

Source: Kauffman Firm Survey, 2011 release.

Finally, Tables 4 and 5 show the industry choice for women- and men-owned firms. As expected, we can see that a high percentage of women locate in the "retail trade" industry, with 15.4 percent (NAICS 44 and 45) of women-owned firms at startup in 2004. Surprisingly, the "professional, scientific, and technical services" industry did better, with 21.84 percent of women-owned firms starting in 2004. "Other services" is third, with 11.68 percent of women choosing it for their firms in 2004. Lastly, "manufacturing" was another preferred industry for women, with 10.79 percent. Excluding "professional, scientific, and technical services" the analysis, men seemed to be more present in the "manufacturing" and "construction" industries. "Other services" is only the fourth industry where men choose to operate. Tables 3.4 and 3.5 clearly show a difference in genders' industrial distribution.

${ }^{97}$ As stated previously, the KFS oversampled firms in NAICS 54. 
Table 3.4

Women-Owned Firms' Industry Distribution

\begin{tabular}{|c|c|c|c|c|c|c|c|}
\hline \multirow[b]{2}{*}{ NAICS } & \multirow[b]{2}{*}{ Industry description } & \multicolumn{2}{|c|}{2004} & \multicolumn{2}{|c|}{2007} & \multicolumn{2}{|c|}{2009} \\
\hline & & $\mathrm{N}$ & $\%$ & $\mathrm{~N}$ & $\%$ & $\mathrm{~N}$ & $\%$ \\
\hline 11 & $\begin{array}{l}\text { Agriculture, forestry, fishing and } \\
\text { hunting }\end{array}$ & 9 & 0.73 & 5 & 0.73 & 3 & 0.56 \\
\hline 21 & Mining & 1 & 0.08 & 0 & - & 1 & 0.19 \\
\hline 23 & Construction & 55 & 4.43 & 36 & 5.26 & 25 & 4.69 \\
\hline 31 & Manufacturing & 23 & 1.85 & 13 & 1.9 & 11 & 2.06 \\
\hline 32 & Manufacturing & 42 & 3.38 & 30 & 4.39 & 14 & 2.63 \\
\hline 33 & Manufacturing & 69 & 5.56 & 42 & 6.14 & 26 & 4.88 \\
\hline 42 & Wholesale trade & 55 & 4.43 & 23 & 3.36 & 20 & 3.75 \\
\hline 44 & Retail trade & 83 & 6.69 & 41 & 5.99 & 28 & 5.25 \\
\hline 45 & Retail trade & 108 & 8.7 & 50 & 7.31 & 40 & 7.5 \\
\hline 48 & Transportation and warehousing & 21 & 1.69 & 10 & 1.46 & 8 & 1.5 \\
\hline 49 & Transportation and warehousing & 1 & 0.08 & 1 & 0.15 & 0 & - \\
\hline 51 & Information & 28 & 2.26 & 13 & 1.9 & 12 & 2.25 \\
\hline 52 & Finance and Insurance & 32 & 2.58 & 18 & 2.63 & 18 & 3.38 \\
\hline 53 & $\begin{array}{l}\text { Real Estate and Rental and } \\
\text { Leasing }\end{array}$ & 47 & 3.79 & 28 & 4.09 & 21 & 3.94 \\
\hline 54 & $\begin{array}{l}\text { Professional, Scientific and Tech } \\
\text { serv }\end{array}$ & 271 & 21.84 & 165 & 24.12 & 132 & 24.77 \\
\hline 55 & $\begin{array}{l}\text { Management of companies and } \\
\text { enterprises }\end{array}$ & 2 & 0.16 & 0 & - & 0 & - \\
\hline 56 & $\begin{array}{l}\text { Adm and support and waste } \\
\text { management and remediation }\end{array}$ & 90 & 7.25 & 49 & 7.16 & 38 & 7.13 \\
\hline 61 & Educational Services & 13 & 1.05 & 7 & 1.02 & 6 & 1.13 \\
\hline 62 & Health Care and Social Assist & 68 & 5.48 & 43 & 6.29 & 36 & 6.75 \\
\hline 71 & Arts, entertainment and recreation & 52 & 4.19 & 29 & 4.24 & 25 & 4.69 \\
\hline 72 & Accommodation and food services & 26 & 2.1 & 9 & 1.32 & 9 & 1.69 \\
\hline 81 & $\begin{array}{l}\text { Other Services (except Public } \\
\text { adm) }\end{array}$ & 145 & 11.68 & 72 & 10.53 & 60 & 11.26 \\
\hline Total & & 1241 & 100 & 684 & 100 & 533 & 100 \\
\hline
\end{tabular}

Source: Tabulation of the Kauffman Firm Survey, 2011 release. 
Table 3.5

Men-Owned Firms' Industry Distribution

\begin{tabular}{llcccccc}
\hline & & \multicolumn{2}{c}{2004} & \multicolumn{2}{c}{2007} & \multicolumn{2}{c}{2009} \\
\hline NAICS & Industry description & $\mathrm{N}$ & $\%$ & $\mathrm{~N}$ & $\%$ & $\mathrm{~N}$ & $\%$ \\
\hline 11 & Agriculture, forestry, fishing and hunting & 28 & 0.79 & 29 & 0.83 & 26 & 0.91 \\
21 & Mining & 4 & 0.11 & 4 & 0.12 & 4 & 0.14 \\
22 & Utilities & 6 & 0.17 & 7 & 0.2 & 7 & 0.25 \\
$\mathbf{2 3}$ & Construction & $\mathbf{3 2 3}$ & $\mathbf{9 . 0 9}$ & $\mathbf{3 2 1}$ & $\mathbf{9 . 2 4}$ & $\mathbf{2 7 6}$ & $\mathbf{9 . 6 6}$ \\
31 & Manufacturing & 27 & 0.76 & 36 & 1.04 & 38 & 1.33 \\
32 & Manufacturing & 105 & 2.96 & 91 & 2.62 & 83 & 2.91 \\
$\mathbf{3 3}$ & Manufacturing & $\mathbf{4 3 1}$ & $\mathbf{1 2 . 1 3}$ & $\mathbf{3 6 0}$ & $\mathbf{1 0 . 3 6}$ & $\mathbf{2 9 9}$ & $\mathbf{1 0 . 4 7}$ \\
42 & Wholesale trade & 160 & 4.5 & 177 & 5.09 & 146 & 5.11 \\
44 & Retail trade & 197 & 5.55 & 198 & 5.7 & 144 & 5.04 \\
45 & Retail trade & 131 & 3.69 & 150 & 4.32 & 114 & 3.99 \\
48 & Transportation and warehousing & 76 & 2.14 & 72 & 2.07 & 57 & 2 \\
49 & Transportation and warehousing & 9 & 0.25 & 6 & 0.17 & 6 & 0.21 \\
51 & Information & 131 & 3.69 & 119 & 3.42 & 95 & 3.33 \\
52 & Finance and Insurance & 150 & 4.22 & 140 & 4.03 & 91 & 3.19 \\
53 & Real Estate and Rental and Leasing & 127 & 3.58 & 135 & 3.88 & 106 & 3.71 \\
$\mathbf{5 4}$ & Professional, Scientific and Tech serv & $\mathbf{8 9 1}$ & $\mathbf{2 5 . 0 8}$ & $\mathbf{8 7 5}$ & $\mathbf{2 5 . 1 8}$ & $\mathbf{7 4 8}$ & $\mathbf{2 6 . 1 8}$ \\
55 & Management of companies and enterprises & 7 & 0.2 & 5 & 0.14 & 5 & 0.18 \\
$\mathbf{5 6}$ & Adm, support, waste management and remediation & $\mathbf{2 5 8}$ & $\mathbf{7 . 2 6}$ & $\mathbf{2 4 9}$ & $\mathbf{7 . 1 7}$ & $\mathbf{2 0 5}$ & $\mathbf{7 . 1 8}$ \\
61 & Educational Services & 16 & 0.45 & 24 & 0.69 & 17 & 0.6 \\
62 & Health Care and Social Assist & 51 & 1.44 & 65 & 1.87 & 60 & 2.1 \\
71 & Arts, entertainment and recreation & 52 & 1.46 & 61 & 1.76 & 48 & 1.68 \\
72 & Accommodation and food services & 71 & 2 & 57 & 1.64 & 46 & 1.61 \\
$\mathbf{8 1}$ & Other Services (except Public adm) & $\mathbf{2 9 8}$ & $\mathbf{8 . 3 9}$ & $\mathbf{2 9 2}$ & $\mathbf{8 . 4}$ & $\mathbf{2 3 3}$ & $\mathbf{8 . 1 6}$ \\
92 & Public Administration & 3 & 0.08 & 2 & 0.06 & 3 & 0.11 \\
$\mathbf{T o t a l}$ & & 3552 & 100 & 3475 & 100 & 2857 & 100 \\
\hline $\mathbf{5 0}$ & & & & & &
\end{tabular}

Source: Tabulation of the Kauffman Firm Survey, 2011 release.

\subsection{The Empirics}

- Survival analysis

I use a Cox proportional hazard model throughout the entire survival analysis. Industry fixed effects are controlled for throughout the survival analysis. 


\section{- A comparison of the women- and men-owned firms subsample}

I first follow the empirical techniques set in some studies such as Boden and Nucci (2000) and compare the survival prospects of women- and men-owned firms on the different variables.

It has been explained throughout this paper that size is an important contributor to survival. The literature has shown a difference in firms' size, on average, between women- and men-owned firms. Theoretically, I do not see a reason why the marginal increase of one employee would be more beneficial for one gender's firm's survival over the other if the external effects - such as the link between size and debt-are controlled. Whether or not this is true remains an empirical issue. The second variable worth investigating is the effect of being a homeoperated business. I do expect that a business operated from home is more likely to fail than a business operated from an office. However, whether or not one particular gender is more penalized by operating from home is unclear. On the one hand, women are more likely to selfselect to work from home to take care of domestic tasks. Thus, if women are spending some working hours on domestic tasks, it is reasonable to assume they are spending fewer hours on their firms. On the other hand, men are less likely to self-select working from home and therefore less likely to spend their working hours on domestic tasks. Therefore, a man's choice to operate his business from home is most likely the result of higher liquidity constraints ${ }^{98}$.

The financial sources a firm uses differ, on average, by gender. Literature has reported that women are less likely to file requests for loans from financial institutions (Coleman and Robb 2009). As Lee and Zhang did in their working paper, I differentiated the models by breaking down the sources of equity.

\footnotetext{
${ }^{98}$ According to Evans and Jovanovic (1989), one's propensity to be self-employed — and his/her success— is positively related to the entrepreneur's wealth.
} 
I ran three models that can generally be written, at time $(\mathrm{t})$, as:

$h_{j}(t)=h_{0}(t) e^{\left(\beta_{0}+\text { Size }_{j i} \beta_{\text {size }}+\text { Home }_{j t} \beta_{\text {Home }}+\text { Finance }_{j t} \beta_{\text {finance }}+\text { Experience }_{j i t} \beta_{\text {exp erience }}+C A_{j t} \beta_{C A}{ }^{+} \mathcal{E}_{t}\right)}$, where $h_{j}$ represents the hazard faced by subject $\mathrm{j}$ and $h_{0}$ represents the baseline hazard that everyone faces within the gender group. The variable size is the total number of employees in the firm $\mathrm{j}$. The variable "home" is equal to one (home=1) if the firm is operated from home. The vector "finance" contains total debt and total equity used by $\mathrm{j}$. The difference between the three models relies on this last variable. The first model, M1, uses total debt and total equity values while the other two models break down equity. The M2 model differentiates total equity between owners-operators' and non-owners operators' equity. The M3 model differentiates non-ownersoperators' equity from formal and informal sources. "Experience" is a proxy of human capital that consists of the primary owner's experience in the industry. Finally, "CA" (competitive advantage) is a variable that proxies for owner's confidence. Competitive advantage is equal to one $(\mathrm{CA}=1)$ if the respondent believed the firm holds a competitive advantage over its competition.

The results are presented in Table 3.6. Perhaps the most surprising result is that the marginal effect of one employee is slightly more beneficial to women for survival (the difference in coefficients is smaller than the standard errors). The same analysis can be done for one year of "experience". The results on "size" may be the caused ${ }^{99}$ by women's style of leadership that stresses the importance of a good relationship with their employees and a management style that accentuates their employees' motivation (Sheppard 1992). The belief of holding a competitive advantage has a higher negative effect on failure for men. The results associated with men-owned firms belief in holding a competitive advantage could be because men are more conservative

\footnotetext{
${ }^{99}$ Further research is needed in order to find the reasons for this result.
} 
when estimating their competitive advantage or that men better understand how to use their competitive advantage. Regarding the financial variables, overall, holding any kind of equity increases failure rates (only the coefficient on non-owners-operators- non-formal equity on the men-owned subsample is significant.); while holding debt seems to decrease failure rates (none of the coefficients on debt is significant). These results echo Lee and Zhang's findings. Finally, operating a business increases failure rates in both subsamples, although the women subsample has slightly lower coefficients for "home-operated".

- The survival analysis for women's hazard rate

In this section, I seek a reason that could explain why women-owned firms are more likely to exit. The empirical model makes use of interactive variables that would represent the variables' effects on women-owned firms. The variable of interest is "gender" which represents women-owned-firms (gender=1 if the firm is owned by a woman). The basic model B0 seeks to confirm that women are indeed more likely to exit.

Once this is established, I run successive models successively adding variables. Each additional model is contingent on whether I have found the "gender" variable to be significant in the previous model. First, among the most likely contenders to explain women-owned firms' higher likelihood of exit, I expect the firm's size to matter; also, women have a higher tendency to run their businesses from home, which could also be a possible cause for women's higher failure rates, as these two variables have a very large difference between women- and men-owned firms. If none of these variables succeeds in explaining the gender coefficient, I add the financial vector that includes "total debt" and "total equity." The next option is to add the main owner's experience and its squared value to control for the non-monotonic trait of the experience function. The last added control is "competitive advantage," which is the closest proxy the KFS provides that can be used for sociological and psychological differences between women and men. 
The model can generally be expressed as follows at time any time $(\mathrm{t})$ :

$h_{j}(t)=h_{0}(t) e^{\left(\beta_{0}+\text { Gender }_{j t} \beta_{\text {gender }}+X_{j t} \beta_{X}+\left(X_{j t} \times \text { Gender }_{j t}\right) \beta_{x \times g}+\mathcal{E}_{t}\right)}$,

where "gender" represents a vector of dummies equal to one if the firm is owned by a woman (gender=1 if $j$ is woman-owned). $X_{j}$ represents the vector for the control variables ${ }^{100}$ discussed above, and $\left(X_{j} \times\right.$ Gender $)$ represents the vector of interactive variables. Note that the coefficients in $\beta_{x}$ should be the ones from the corresponding variables on men-owned firms, while $\beta_{x \times g}$ represents the difference between the women- and men-owned coefficients in the subsample survival analysis. The results are presented in Table 3.7.

The B0 model confirms that women-owned firms are indeed more likely to fail, as the coefficient on gender is positive and statistically significant. The next model adds the firm's size and an interactive variable for women-owned firms' size. As expected, the coefficient on firms' size confirms that size decreases the men-owned firms' hazard rate. However, the coefficient on the size*gender indicates that the difference between women and men is not statistically significant in the model. Moreover, the coefficient on gender is still positive and significant. Therefore, I conclude that the difference in size among women- and men-owned firms cannot explain the difference in survival rates within genders. M2 adds the home-operated business dummy and its interactive variable. The results suggest that a home-based firm increases a menowned firm's hazard rate, as the coefficient on home is positive and significant. The surprising result is that the higher trend for women to operate their businesses from home does not explain their higher failure rates. The coefficient on gender remains significant—and positive- - while the coefficient on home*gender is insignificant. The results found on total debt and the corresponding interactive variable are insignificant, and I deduce that they, too, cannot explain the women-

\footnotetext{
${ }^{100} \mathrm{Chi}$-squared tests were conducted on the different variables, and the results are presented in Appendix 3.3.
} 
owned firms' higher likelihood of failure. The coefficient on the equity interactive variable is insignificant, implying that this variable also fails to explain the reasons behind women-owned firms' higher failure rates.

Adding experience (and experience squared) in M3 does not change the behavior of the model. The coefficient on gender remains significant and increases again. So far, the coefficient on gender increased from 0.132 to 0.302 while controlling for size, home-operation, use of debt and equity and experience. Taking into account the results reported in Table 3.6, this is not surprising. Women have better coefficients (for survival) in the variables used so far. Thus, it is expected that controlling for these variables increases the coefficient on gender. Intuitively, however, these results indicate that the negative effect on a firm's survival probability for being women-owned is increasing when the controls cited previously are added to the model.

The last model, M4, adds the competitive-advantage dummy variable. The coefficient on gender becomes insignificant. The point estimate on gender drops from 0.302 to 0.194 (from M3 to M4) and increases overall from 0.132 to 0.194 (from B0 to M4). Unfortunately, the increase from B0 to M4 is smaller in magnitude than the standard errors, and therefore both coefficients can be considered similar. Therefore, the last model was also unable to explain women's higher failure rates on the firms' survival. 
Table 3.6

Survival Analysis with Gender Subsamples

\begin{tabular}{|c|c|c|c|c|c|c|}
\hline \multirow[b]{2}{*}{ VARIABLES } & \multicolumn{2}{|c|}{ M1 } & \multicolumn{2}{|c|}{ M2 } & \multicolumn{2}{|c|}{ M3 } \\
\hline & $\begin{array}{c}\text { Women- } \\
\text { owned }\end{array}$ & Men-owned & $\begin{array}{c}\text { Women- } \\
\text { owned }\end{array}$ & Men-owned & $\begin{array}{c}\text { Women- } \\
\text { owned }\end{array}$ & Men-owned \\
\hline Size & $\begin{array}{c}-0.0704 * * * \\
(0.0263)\end{array}$ & $\begin{array}{c}-0.0568 * * * \\
(0.0130)\end{array}$ & $\begin{array}{c}-0.0739 * * * \\
(0.0269)\end{array}$ & $\begin{array}{c}-0.0605 * * * \\
(0.0133)\end{array}$ & $\begin{array}{c}-0.0740 * * * \\
(0.0270)\end{array}$ & $\begin{array}{c}-0.0593 * * * \\
(0.0132)\end{array}$ \\
\hline Home-operated & $\begin{array}{c}0.270 * * \\
(0.129)\end{array}$ & $\begin{array}{c}0.371 * * * \\
(0.0858)\end{array}$ & $\begin{array}{c}0.285^{* *} \\
(0.129)\end{array}$ & $\begin{array}{c}0.377 * * * \\
(0.0858)\end{array}$ & $\begin{array}{c}0.286^{* *} \\
(0.130)\end{array}$ & $\begin{array}{l}0.381 * * * \\
(0.0859)\end{array}$ \\
\hline Total debt & $\begin{array}{l}-0.00449 \\
(0.0452)\end{array}$ & $\begin{array}{c}0.0200 \\
(0.0237)\end{array}$ & $\begin{array}{l}-0.0224 \\
(0.0471)\end{array}$ & $\begin{array}{c}0.0122 \\
(0.0238)\end{array}$ & $\begin{array}{l}-0.0243 \\
(0.0477)\end{array}$ & $\begin{array}{c}0.0121 \\
(0.0240)\end{array}$ \\
\hline Total equity & $\begin{array}{l}-0.206 \\
(0.174)\end{array}$ & $\begin{array}{l}-0.120 * * \\
(0.0573)\end{array}$ & & & & \\
\hline Total equity owners-operators & & & $\begin{array}{l}-0.0244 \\
(0.0937)\end{array}$ & $\begin{array}{c}-0.0877 * \\
(0.0504)\end{array}$ & $\begin{array}{l}-0.0252 \\
(0.0931)\end{array}$ & $\begin{array}{c}-0.0895 * \\
(0.0499)\end{array}$ \\
\hline Total equity non owners-operators & & & $\begin{array}{l}0.0105 \\
(0.123)\end{array}$ & $\begin{array}{c}0.0516 \\
(0.0448)\end{array}$ & & \\
\hline Total equity non owners-operators, non-formal & & & & & $\begin{array}{l}0.0547 \\
(0.177)\end{array}$ & $\begin{array}{c}0.184 * * * \\
(0.0670)\end{array}$ \\
\hline Total equity non owners-operators, formal & & & & & $\begin{array}{l}0.0225 \\
(0.132)\end{array}$ & $\begin{array}{c}0.0102 \\
(0.0459)\end{array}$ \\
\hline Experience & $\begin{array}{c}-0.0580 * * * \\
(0.0197)\end{array}$ & $\begin{array}{c}-0.0441 * * * \\
(0.0118)\end{array}$ & $\begin{array}{c}-0.0575 * * * \\
(0.0197)\end{array}$ & $\begin{array}{c}-0.0441 * * * \\
(0.0118)\end{array}$ & $\begin{array}{c}-0.0574 * * * \\
(0.0197)\end{array}$ & $\begin{array}{c}-0.0439 * * * \\
(0.0118)\end{array}$ \\
\hline Experience squared & $\begin{array}{l}0.00148 * * \\
(0.000648)\end{array}$ & $\begin{array}{c}0.000937 * * * \\
(0.000327)\end{array}$ & $\begin{array}{l}0.00146 * * \\
(0.000651)\end{array}$ & $\begin{array}{c}0.000939 * * * \\
(0.000327)\end{array}$ & $\begin{array}{l}0.00146 * * \\
(0.000651)\end{array}$ & $\begin{array}{c}0.000937 * * * \\
(0.000327)\end{array}$ \\
\hline Competitive advantage & $\begin{array}{c}-0.270^{* *} \\
(0.115)\end{array}$ & $\begin{array}{c}-0.487 * * * \\
(0.0780)\end{array}$ & $\begin{array}{c}-0.269^{* *} \\
(0.115)\end{array}$ & $\begin{array}{c}-0.494 * * * \\
(0.0780)\end{array}$ & $\begin{array}{c}-0.269 * * \\
(0.115)\end{array}$ & $\begin{array}{c}-0.497 * * * \\
(0.0782)\end{array}$ \\
\hline Observations & 4,255 & 12,528 & 4,257 & 12,539 & 4,257 & 12,539 \\
\hline
\end{tabular}


Table 3.7

Survival Analysis for the Gender Effect using Interaction Variables

\begin{tabular}{|c|c|c|c|c|c|c|}
\hline VARIABLES & B0 & M0 & M1 & M2 & M3 & M4 \\
\hline \multirow[t]{2}{*}{ Gender } & $0.132 * *$ & $0.228 * *$ & $0.269^{*}$ & $0.282 *$ & $0.302 *$ & 0.194 \\
\hline & $(0.0656)$ & $(0.102)$ & $(0.146)$ & $(0.147)$ & $(0.182)$ & $(0.188)$ \\
\hline \multirow[t]{2}{*}{ Size } & & $-0.0870 * * *$ & $-0.0675 * * *$ & $-0.0652 * * *$ & $-0.0614 * * *$ & $-0.0554 * * *$ \\
\hline & & $(0.0132)$ & $(0.0126)$ & $(0.0127)$ & $(0.0132)$ & $(0.0128)$ \\
\hline \multirow[t]{2}{*}{ Gender $*$ Size } & & -0.0101 & -0.0129 & -0.00898 & -0.0162 & -0.0183 \\
\hline & & $(0.0306)$ & $(0.0293)$ & $(0.0288)$ & $(0.0296)$ & $(0.0292)$ \\
\hline \multirow[t]{2}{*}{ Home-operated } & & & $0.396 * * *$ & $0.383 * * *$ & $0.396 * * *$ & $0.367 * * *$ \\
\hline & & & $(0.0827)$ & $(0.0835)$ & $(0.0853)$ & $(0.0853)$ \\
\hline \multirow[t]{2}{*}{ Home-operated $*$ Gender } & & & -0.0735 & -0.0791 & -0.123 & -0.119 \\
\hline & & & $(0.145)$ & $(0.146)$ & $(0.147)$ & $(0.146)$ \\
\hline \multirow[t]{2}{*}{ Total debt } & & & & 0.0284 & 0.0228 & 0.0235 \\
\hline & & & & $(0.0230)$ & $(0.0238)$ & $(0.0237)$ \\
\hline \multirow[t]{2}{*}{ Total debt $*$ Gender } & & & & -0.0324 & -0.0356 & -0.0324 \\
\hline & & & & $(0.0504)$ & $(0.0509)$ & $(0.0506)$ \\
\hline \multirow[t]{2}{*}{ Total equity } & & & & $-0.113 * *$ & $-0.131 * *$ & $-0.120 * *$ \\
\hline & & & & $(0.0522)$ & $(0.0582)$ & $(0.0568)$ \\
\hline \multirow[t]{2}{*}{ Total equity $*$ Gender } & & & & -0.0971 & -0.0820 & -0.0918 \\
\hline & & & & $(0.186)$ & $(0.188)$ & $(0.184)$ \\
\hline \multirow[t]{2}{*}{ Experience } & & & & & $-0.0474 * * *$ & $-0.0445 * * *$ \\
\hline & & & & & $(0.0117)$ & $(0.0117)$ \\
\hline \multirow[t]{2}{*}{ Experience squared } & & & & & $0.00102 * * *$ & $0.000950 * * *$ \\
\hline & & & & & $(0.000326)$ & $(0.000325)$ \\
\hline \multirow[t]{2}{*}{ Experience $*$ Gender } & & & & & -0.0123 & -0.0143 \\
\hline & & & & & $(0.0224)$ & $(0.0223)$ \\
\hline \multirow[t]{2}{*}{ Experience squared $*$ Gender } & & & & & 0.000446 & 0.000504 \\
\hline & & & & & $(0.000724)$ & $(0.000718)$ \\
\hline \multirow[t]{2}{*}{ Competitive adv } & & & & & & $-0.491 * * *$ \\
\hline & & & & & & $(0.0777)$ \\
\hline \multirow[t]{2}{*}{ Competitive adv * Gender } & & & & & & $0.239 *$ \\
\hline & & & & & & $(0.138)$ \\
\hline Observations & 20,607 & 17,188 & 17,188 & 17,174 & 16,783 & 16,783 \\
\hline
\end{tabular}

Robust standard errors in parentheses; ${ }^{* * *} \mathrm{p}<0.01,{ }^{* *} \mathrm{p}<0.05,{ }^{*} \mathrm{p}<0.1$ 


\subsection{Conclusion}

This study updates the literature on the effects of gender differences on firms' survival rates. Using the KFS, a recent dataset that surveyed firms founded in 2004, I confirm the literature findings that women-owned firms are more likely to fail. By separating the sample into two subsamples of women- and men-owned firms, I compare the effects of previously studied variables, such as firms' size, human capital, financial capital use, and home-operated businesses on survival. I add a variable never used previously, as far as I know: self-reported competitive advantage, which proxies for owners' confidence.

The summary statistics also showed that the percentage of women operating from home was not decreasing as firms were aging, as opposed to men-owned firms. Moreover, the percentage of women operating from home increased from 2004 to 2005 . Considering that operating from home is found to increase the hazard rate, I assume that this increase in homeoperated businesses was due to a flow of women-owned firms from a professional work environment back to their home (maybe because they started a family). More research is needed to determine whether this proposition is correct.

The model, which analyses both genders' subsamples, has been used before in the literature. The results indicate that a marginal employee hired by a women-owned firm had a greater contribution to survival than one marginal employee on men-owned firms. More research towards genders' different styles of management should be conducted to determine whether this result was the product of greater employee motivation associated with women's style of management.

A marginal year of experience for the main owner in the industry the firm is competing in had a similar contribution for each gender (although it was slightly higher for women), indicating that experience is used similarly across genders. Thus, assuming that experience does play a role in explaining genders' differences in failure rates, it must be that it is the difference in experience 
levels that penalizes women-owned firms. Indeed, women are less experienced on average. The genders-separated survival analysis also shows that women-owned firms' self-reported belief in holding a competitive advantage was a lower contributor for survival than it was for men-owned firms. The summary statistics showed that women-owned firms, on average, thought more often than men that they held a competitive advantage. The higher proportion of women-owned firms to believe they held a competitive advantage is a hint that women-owned firms may be overconfident (or men are more careful) in claiming they have a competitive advantage, which, considering Koellinger, et al. (2007), should increase women-owned firms' failure rates. The results could also indicate that men better utilize their competitive advantage. I also find that operating a business from home increases the hazard rate for both men and women. More research is needed to assert with certainty which of the reasons stated previously is the most plausible.

After confirming that women-owned firms are more likely to fail, I seek a reason using a new survival model. With the use of gender-interactive variables, I investigate whether the differences in the coefficients across genders found in the first survival model are important enough to force women-owned firms to fail more frequently. I find that the difference in coefficients for variables previously thought to be the reasons behind women-owned firms' higher likelihood of failure were insignificant within the KFS.

Variables such as size, home-operated businesses, financing and experience were not enough to explain the coefficient on gender. I added "competitive advantage" in the last model. The difference in the gender coefficients on competitive advantage was significant, while gender became insignificant. The coefficient on gender decreased from the previous model (M3) while increasing from the base model (B0). Before me, Carter et al. (1997) had found that differences in management styles were very important in analyzing genders firms' survival. 
Despite findings that contribute to the literature by confirming that differences in sociological and psychological factors across genders are part of the explanation for womenowned firms' higher failure rates, this study was not able to explain the entire gender effect on firms' survival. 


\section{REFERENCES}

Aldrich, H.E.1989. Networking among women entrepreneurs. In 0. Hagan, C. Rivchun, \& D. Sexton (Eds.), Women-owned businesses: 103-132. New York: Praeger.

Aldrich, H. E. \& Auster, E.R., 1986. Even dwarfs started small: Liabilities of age and size and their strategic implications. Research in Organizational Behavior, 8, pp.165-198.

Anna, A.L., Chandler, G.N., Jansen, E. \& Mero, N.R., 2000. Women business owners in traditional and non-traditional industries. Journal of Business Venturing, 15(3), pp.279303.

Åstebro, T. \& Bernhardt, I., 2003. Start-up financing, owner characteristics, and survival. Journal of Economics and Business, 55(4), pp.303-319.

Bates, T., 1995. A comparison of franchise and independent small business survival rates. Small Business Economics, 7(5), pp.377-388.

Bates, T. \& Nucci, A., 1989. An analysis of small business size and rate of discontinuance. Journal of Small Business Management, 27, pp.1-7.

Birley, S., 1989. Female Entrepreneurs: Are they really any different? Journal of Small Business Management, pp.32-37.

Boden JR., R.J. \& Nucci, A.R., 2000. On the survival prospects of men's and women's new business ventures. Journal of Business Venturing, 15(4), pp.347-362.

Brüderl, J., Preisendörfer, P. \& Ziegler, R., 1992. Survival chances of newly founded business organizations. American Sociological Review, 57(2), pp.227-242.

Brush, C.G., 1992. Research on women business owners: Past trends, a new perspective and future directions. Entrepreneurship Theory and Practice, 16(2), pp.6-30.

Brush, C.G. \& Chaganti, R., 1999. Businesses without glamour? An analysis of resources on performance by size and age in small service and retail firms. Journal of Business Venturing, 14(3), pp.233-257.

Burns, H., Carter, S., Hamilton, D., \& Rosa, P., 1994. The impact of gender on small business management: preliminary findings of a British study. International Small Business Journal, 12, pp.25-32.

Carter, N.M., Williams, M. \& Reynolds, P.D., 1997. Discontinuance among new firms in retail: The influence of initial resources, strategy, and gender. Journal of Business Venturing, 12(2), pp.125-145.

Cassar, G. \& Craig, J., 2009. An investigation of hindsight bias in nascent venture activity. Journal of Business Venturing, 24(2), pp.149-164. 
Charboneau, F.J., 1981. The woman entrepreneur. American Demographics, pp.21-23.

Churchill, B.C., 1952. Survival Patterns of the Postwar Business Population. Survey of Current Business, pp.12-19.

Cliff, J.E., 1998. Does one size fit all? Exploring the relationship between attitudes towards growth, gender, and business size. Journal of Business Venturing, 13(6), pp.523-542.

Cole, R.A. \& Mehran, H., 2011. Gender and the availability of credit to privately held firms: Evidence from the Surveys of Small Business Finances, Available at: SSRN: http://ssrn.com/abstract=1799649.

Coleman, S., 2002. Characteristics and borrowing behavior of small, women-owned firms: Evidence from the 1998 Survey of Small Business Finances. Journal of Business and Entrepreneurship, 14(2), pp.151-166.

Coleman, S. \& Robb, A., 2009. A comparison of new firm financing by gender: evidence from the Kauffman Firm Survey data. Small Business Economics, 33(4), pp.397-411.

Constantinidis, C., Cornet, A. \& Asandei, S., 2006. Financing of women-owned ventures: The impact of gender and other owner -and firm-related variables. Venture Capital, 8(2), pp.133-157.

Cooper, A.C., Gimeno-Gascon, F.J. \& Woo, C.Y., 1994. Initial human and financial capital as predictors of new venture performance. Journal of Business Venturing, 9(5), pp.371-395.

Cox, D.R., 1972. Regression models and life-tables. Journal of the Royal Statistical Society. Series B (Methodological), 34(2), pp.187-220.

Cromie, S. \& Birley, S., 1991. Networking by female business owners in Northern Ireland. Journal of Business Venturing, 7(3), pp.237-251.

Cuba, R., DeCenzo, D. \& Anish, A., 1983. Management practices of successful female business owners. American Journal of Small Business, 8(2), pp.40-46.

Du Rietz, A. \& Henrekson, M., 2000. Testing the female underperformance hypothesis. Small Business Economics, 14(1), pp.1-10.

Dunne, T., Roberts, M.J. \& Samuelson, L., 1989. The Growth and failure of U. S. manufacturing plants. The Quarterly Journal of Economics, 104(4), pp.671-698.

Evans, D.S., 1987. The Relationship between firm growth, size, and age: Estimates for 100 manufacturing industries. The Journal of Industrial Economics, 35(4), pp.567-581.

Evans, D.S. \& Jovanovic, B., 1989. An estimated model of entrepreneurial choice under liquidity constraints. Journal of Political Economy, 97(4), pp.808-827. 
Fairlie, R.W. \& Robb, A.M., 2009. Gender differences in business performance: evidence from the Characteristics of Business Owners survey. Small Business Economics, 33(4), pp.375375-395.

Fasci, M.A. \& Valdez, J., 1998. A performance contrast of male- and women-owned small accounting practices. Journal of Small Business Management, 36(3), pp.1-7.

Forbes, D.P., 2005. Are some entrepreneurs more overconfident than others? Journal of Business Venturing, 20(5), pp.623-640.

Geroski, P.A., Mata, J. \& Portugal, P., 2010. Founding conditions and the survival of new firms. Strategic Management Journal, 31(5), pp.510-529.

Gordon, R.H., 1998. Can high personal tax rates encourage entrepreneurial activity? International Monetary Fund Staff Papers. 45(1), pp 49-80.

Headd, B., 2003. Redefining business success: Distinguishing between closure and failure. Small business economics, 21(1), pp.51-61.

Hisrich, R.D., 1985. The Woman Entrepreneur: Characteristics, skills, problems, and prescriptions for success. In D. L. Sexton \& R. W. Smilor, eds. The Art and Science of Entrepreneurship. Cambridge, Mass: Ballinger Publishing Company.

Honing-Haftel, S. \& Martin, L., 1986. Is the female entrepreneur at a disadvantage? The Journal for Employment and Training Professionals, 7, pp.49-64.

Humphreys, M.A. \& McClung, J., 1981. Women entrepreneurs in Oklahoma. Review of Regional Economics and Business, 6(2), pp.13-21.

Hutchinson, R.G., Hutchinson, A.R. \& Newcomer, M., 1938. A Study in business mortality: Length of life of business enterprises in Poughkeepsie, New York, 1843-1936. The American Economic Review, 28(3), pp.497-514.

Jovanovic, B., 1980. Selection and the evolution of industry. Econometrica, 50(3), pp.649-670.

Kalleberg, A.L. \& Leicht, K.T., 1991. Gender and organizational performance: determinants of small business survival and success. The Academy of Management Journal, 34(1), pp.136-161.

Koellinger, P., Minniti, M. \& Schade, C., 2007. "I think I can, I think I can": Overconfidence and entrepreneurial behavior. Journal of Economic Psychology, 28(4), pp.502-527.

Lee, J. \& Zhang, W., 2010. Financial capital and startup survival. SSRN. Available at: http://ssrn.com/abstract=1659046. 
Mahot, P., 1997. Le financement des femmes chefs d'entreprise, une difficulte reelle, neanmoins controversee. Presented at the 1997 OECD Conference on Women Entrepreneurs in Small and Medium Enterprises: A Major Force in Innovation and Job Creation in Paris.

Mata, J. \& Portugal, P., 1994. Life duration of new firms. The Journal of Industrial Economics, 13, pp.227-245.

Menzies, T.V., Diochon, M. \& Gasse, Y., 2004. Examining venture-related myths concerning women entrepreneurs. Journal of Developmental Entrepreneurship, 9(2), pp.89-107.

Neider, L., 1987. A preliminary investigation of female entrepreneurs in Florida. Journal of Small Business Management, 25(3), pp.22-29.

Orban, M., 2001. Women business owners in France: The Issue of Financing Discrimination. Journal of Small Business Management, 39, pp.95-102.

Orser, B. \& Hogarth-Scott,, S, 2002. Opting for growth: Gender dimensions of choosing enterprise development. Canadian Journal of Administrative Sciences / Revue Canadienne des Sciences de l'Administration, 19(3), pp.284-300.

Orser, B.J., Hogarth-Scott, S. \& Riding, A.L., 2000. Performance, firm size, and management problem solving. Journal of Small Business Management, 38, pp.42-59.

Reese, P., 1992. Resource acquisition: Does gender make a difference? Presented at The Second Annual Global Entrepreneurship Research Conference in London.

Robb, A. \& Wolken, J.D., 2002. Firm, owner, and financing characteristics: differences between female- and men-owned small businesses, Washington, D.C.: Divisions of Research \& Statistics and Monetary Affairs, Federal Reserve Board.

Rosa, P., Carter, S. \& Hamilton, D., 1996. Gender as a determinant of small business performance: Insights from a british study. Small Business Economics, 8(4), pp.463-478.

Sheppard, D., 1992. Women manager's perceptions of gender and organizational life A. J. Mills \& p Tancred, eds. Sage Publications, Newbury Park, CA.

Thompson, P., 2005. Selection and firm survival: Evidence from the shipbuilding industry, 18251914. The Review of Economics and Statistics, 87(1), pp.26-36.

Tigges, L.M. \& Green, G.P., 1994. Small business success among men- and women-owned firms in rural areas1. Rural Sociology, 59(2), pp.289-310.

Treichel, M.Z. \& Scott, J.A., 2006. Women-owned businesses and access to bank credit: Evidence from three surveys since 1987. Venture Capital, 8(1), pp.51-67. 
Van de Ven, A.H., Hudson, R. \& Schroeder, D.M., 1984. Designing new business startups: Entrepreneurial, organizational, and ecological considerations. Journal of Management, $10(1)$, pp. $87-108$.

Watson, J., 2003. Failure rates for female-controlled businesses: are they any different? Journal of Small Business Management, 41, pp.262-277.

Watson, J. \& Everett, J., 1999. Small business failure rates: choice of definition and industry effects. International Small Business Journal, 17(2), pp.31-47. 


\section{APPENDICES}

\section{Appendix 1}

\section{Appendix 1.1}

Regressions results with the firm's total number of employees variable including the firm's number of owner-operators. The first and second columns show the results of the first year survival probability using 2004 conditions. The third and fourth columns show the results of the probability of survival in the last year of the survey (2007) using founding conditions. The results are pretty straightforward. Including the firm's owner-operators to the number of employees for a measure of size do not change anything in the regressions whether it be on current conditions or on founding conditions (See Appendix 1.1 below for results).

\section{Appendix 1.2}

Regressions results using two measures of industry scale like Åstebro and Bernhardt (2003) show that the second measure of scale (percentage of firms in the two digit sic industry employing fewer than 50 employees) is not useful in my study. The second measure of scale is found to be insignificant in the current conditions regression and both measure of scale are found to be insignificant in the founding conditions regression (see Appendix 1.2 below for results). 
Appendix 1.1

Regressions Adding the Firm's Owner-operators to the Number of Employees

\begin{tabular}{|c|c|c|c|c|}
\hline Model & $\begin{array}{l}\text { M3 in first } \\
\text { year }\end{array}$ & $\begin{array}{l}\text { M3 in first } \\
\text { year }\end{array}$ & $\begin{array}{l}\text { Founding } \\
\text { conditions } \\
\text { using } M 3\end{array}$ & $\begin{array}{l}\text { Founding } \\
\text { conditions } \\
\text { using M3 }\end{array}$ \\
\hline & $\begin{array}{c}\text { Model } \\
\text { including } \\
\text { owner- } \\
\text { operators in } \\
\text { total number } \\
\text { of employees }\end{array}$ & $\begin{array}{c}\text { Model } \\
\text { excluding } \\
\text { owner- } \\
\text { operators in } \\
\text { total } \\
\text { number of } \\
\text { employees }\end{array}$ & $\begin{array}{c}\text { Model } \\
\text { including } \\
\text { owner- } \\
\text { operators in } \\
\text { total } \\
\text { number of } \\
\text { employees }\end{array}$ & $\begin{array}{c}\text { Model } \\
\text { excluding } \\
\text { owner- } \\
\text { operators in } \\
\text { total number } \\
\text { of employees }\end{array}$ \\
\hline Control Variables in 2004 & $\begin{array}{l}\text { Probability } \\
\text { of Survival } \\
\text { in year } 2005\end{array}$ & $\begin{array}{l}\text { Probability } \\
\text { of Survival } \\
\text { in year } \\
2005\end{array}$ & $\begin{array}{c}\text { Probability } \\
\text { of Survival } \\
\text { in year } \\
2007\end{array}$ & $\begin{array}{l}\text { Probability of } \\
\text { Survival in } \\
\text { year } 2007\end{array}$ \\
\hline $\begin{array}{l}\text { Total number of employees } \\
\text { without owners operator }\end{array}$ & - & $\begin{array}{c}0.027 \\
(2.40)^{* *}\end{array}$ & - & $\begin{array}{c}0.018 \\
(2.78)^{* * *}\end{array}$ \\
\hline $\begin{array}{l}\text { Total number of employees } \\
\text { with owners operator }\end{array}$ & $\begin{array}{c}0.025 \\
(2.42)^{* *}\end{array}$ & - & $\begin{array}{c}0.019 \\
(3.02)^{* * *}\end{array}$ & - \\
\hline Relevance of experience & $\begin{array}{c}0.029 \\
(3.06)^{* * *}\end{array}$ & $\begin{array}{c}0.03 \\
(3.10)^{* * *}\end{array}$ & $\begin{array}{c}0.034 \\
(5.01)^{* * *}\end{array}$ & $\begin{array}{c}0.034 \\
(5.06)^{* * *}\end{array}$ \\
\hline $\begin{array}{l}\text { Quadratic of the relevance } \\
\text { of experience }\end{array}$ & $\begin{array}{c}-0.001 \\
(2.49)^{* *}\end{array}$ & $\begin{array}{c}-0.001 \\
(2.54)^{* *}\end{array}$ & $\begin{array}{c}-0.001 \\
(3.91)^{* * *}\end{array}$ & $\begin{array}{c}-0.001 \\
(3.98) * * *\end{array}$ \\
\hline Leverage between 0 and 1 & $\begin{array}{c}0.169 \\
(1.93)^{*}\end{array}$ & $\begin{array}{c}0.166 \\
(1.90)^{*}\end{array}$ & $\begin{array}{l}0.028 \\
(0.49)\end{array}$ & $\begin{array}{l}0.028 \\
(0.48)\end{array}$ \\
\hline Leverage equal to 1 & $\begin{array}{c}0.028 \\
(0.3)\end{array}$ & $\begin{array}{l}0.028 \\
(0.29)\end{array}$ & $\begin{array}{c}0.01 \\
(0.15)\end{array}$ & $\begin{array}{l}0.012 \\
(0.18)\end{array}$ \\
\hline Leverage greater than 1 & $\begin{array}{l}-0.15 \\
(1.45)\end{array}$ & $\begin{array}{l}-0.153 \\
(1.47)\end{array}$ & $\begin{array}{c}-0.239 \\
(3.18)^{* * *}\end{array}$ & $\begin{array}{c}-0.24 \\
(3.19)^{* * *}\end{array}$ \\
\hline Leverage is infinite & $\begin{array}{c}-0.2 \\
(2.08)^{* *}\end{array}$ & $\begin{array}{c}-0.203 \\
(2.11)^{* *}\end{array}$ & $\begin{array}{c}-0.203 \\
(2.84)^{* * *}\end{array}$ & $\begin{array}{c}-0.205 \\
(2.87) * * *\end{array}$ \\
\hline $\begin{array}{l}\text { Portion in the industry with } \\
\text { fewer than } 20 \text { employees }\end{array}$ & $\begin{array}{c}1.958 \\
(2.99) * * *\end{array}$ & $\begin{array}{c}1.949 \\
(2.98)^{* * *}\end{array}$ & $\begin{array}{c}1.096 \\
(2.32)^{* *}\end{array}$ & $\begin{array}{c}1.069 \\
(2.26)^{* *}\end{array}$ \\
\hline Constant & $\begin{array}{l}-0.36 \\
(0.62)\end{array}$ & $\begin{array}{l}-0.318 \\
(0.55)\end{array}$ & $\begin{array}{l}-0.331 \\
(0.79)\end{array}$ & $\begin{array}{l}-0.281 \\
(0.67)\end{array}$ \\
\hline Observations & 4366 & 4366 & 4366 & 4366 \\
\hline
\end{tabular}

Absolute value of $\mathrm{z}$ statistics in parentheses

$*$ significant at $10 \%$; * significant at $5 \%$; ** significant at $1 \%$ 
Appendix 1.2

Regressions for Comparison using Åstebro and Bernhardt (2003) two Measures of Scale

\begin{tabular}{|c|c|c|c|c|}
\hline \multirow[b]{2}{*}{ Control Variables in 2004} & M3 on first year & $\begin{array}{c}\text { Astebro and } \\
\text { Bernhardt } \\
\text { (2003): on first } \\
\text { year }\end{array}$ & $\begin{array}{l}\text { M3 on founding } \\
\text { conditions }\end{array}$ & $\begin{array}{l}\text { Astebro and } \\
\text { Bernhardt } \\
\text { (2003) on } \\
\text { founding } \\
\text { conditions }\end{array}$ \\
\hline & $\begin{array}{l}\text { Probability of } \\
\text { Survival in } \\
\text { year } 2005 \\
\text { using one } \\
\text { measure of } \\
\text { industry scale } \\
\text { (M3) }\end{array}$ & $\begin{array}{l}\text { Probability of } \\
\text { Survival in } \\
\text { year } 2005 \\
\text { using two } \\
\text { measures of } \\
\text { industry scale } \\
\text { in M3 }\end{array}$ & $\begin{array}{l}\text { Probability of } \\
\text { Survival in } \\
\text { year } 2007 \\
\text { using one } \\
\text { measure of } \\
\text { industry scale } \\
\text { (M3) }\end{array}$ & $\begin{array}{c}\text { Probability of } \\
\text { Survival in } \\
\text { year } 2007 \\
\text { using two } \\
\text { measures of } \\
\text { industry scale } \\
\text { in M3 }\end{array}$ \\
\hline \multirow[t]{2}{*}{ Total number of employees } & 0.027 & 0.028 & 0.018 & 0.019 \\
\hline & $(2.40)^{* *}$ & $(2.48)^{* *}$ & $(2.78)^{* * *}$ & $(2.77)^{* * *}$ \\
\hline \multirow[t]{2}{*}{ Relevance of experience } & 0.03 & 0.029 & 0.034 & 0.034 \\
\hline & $(3.10)^{* * *}$ & $(3.06)^{* * *}$ & $(5.06)^{* * *}$ & $(5.05)^{* * *}$ \\
\hline \multirow{2}{*}{$\begin{array}{l}\text { Quadratic of the relevance } \\
\text { of experience }\end{array}$} & -0.001 & -0.001 & -0.001 & -0.001 \\
\hline & $(2.54)^{* *}$ & $(2.50)^{* *}$ & $(3.98)^{* * *}$ & $(3.96)^{* * *}$ \\
\hline \multirow[t]{2}{*}{ Leverage between 0 and 1} & 0.166 & 0.168 & 0.028 & 0.028 \\
\hline & $(1.90)^{*}$ & $(1.92)^{*}$ & $(0.48)$ & $(0.48)$ \\
\hline \multirow[t]{2}{*}{ Leverage equal to 1} & 0.028 & 0.032 & 0.012 & 0.013 \\
\hline & $(0.29)$ & $(0.33)$ & $(0.18)$ & $(0.19)$ \\
\hline \multirow[t]{2}{*}{ Leverage greater than 1} & -0.153 & -0.149 & -0.24 & -0.239 \\
\hline & $(1.47)$ & $(1.43)$ & $(3.19)^{* * *}$ & $(3.18)^{* * *}$ \\
\hline \multirow[t]{2}{*}{ Leverage is infinite } & -0.203 & -0.203 & -0.205 & -0.205 \\
\hline & $(2.11)^{* *}$ & $(2.12)^{* *}$ & $(2.87)^{* * *}$ & $(2.87)^{* * *}$ \\
\hline \multirow[t]{2}{*}{$\begin{array}{l}\text { Portion in the industry with } \\
\text { fewer than } 20 \text { employees }\end{array}$} & 1.949 & 3.028 & 1.069 & 1.201 \\
\hline & $(2.98)^{* * *}$ & $(1.97)^{* *}$ & $(2.26)^{* *}$ & -1.04 \\
\hline \multirow{4}{*}{$\begin{array}{l}\text { Portion in the industry with } \\
\text { fewer than } 50 \text { employees } \\
\text { Constant }\end{array}$} & - & -2.484 & - & -0.299 \\
\hline & & $(0.77)$ & & $(0.12)$ \\
\hline & -0.318 & 1.101 & -0.281 & -0.112 \\
\hline & $(0.55)$ & $(0.57)$ & $(0.67)$ & $(0.08)$ \\
\hline Observations & 4366 & 4366 & 4366 & 4366 \\
\hline
\end{tabular}

Absolute value of $\mathrm{z}$ statistics in parentheses

* significant at $10 \% ; * *$ significant at $5 \% ; * * *$ significant at $1 \%$ 
Appendix 1.3

Linear Regressions of Size

\begin{tabular}{|lccc|}
\hline \multicolumn{1}{|c}{$\begin{array}{c}\text { Total number of } \\
\text { employees }\end{array}$} & $\mathbf{2 0 0 5}$ & $\mathbf{2 0 0 6}$ & $\mathbf{2 0 0 7}$ \\
Relevance of & 0.041 & 0.115 & 0.114 \\
experience & $(2.36)^{* *}$ & $(4.56)^{* * *}$ & $(3.92)^{* * *}$ \\
Quadratic of the & -0.001 & -0.002 & -0.003 \\
relevance of experience & $(1.54)$ & $(3.20)^{* * *}$ & $(3.13)^{* * *}$ \\
Leverage between 0 and 1 & 0.79 & 1.174 & 1.291 \\
& $(5.50)^{* * *}$ & $(6.19)^{* * *}$ & $(5.94)^{* * *}$ \\
Leverage equal to 1 & 2.122 & 1.733 & 2.145 \\
& $(12.85)^{* * *}$ & $(6.86)^{* * *}$ & $(7.50)^{* * *}$ \\
Leverage greater than 1 & 0.584 & 0.28 & -0.295 \\
& $(2.91)^{* * *}$ & -0.9 & -0.81 \\
Leverage is infinite & -0.081 & 0.119 & -0.164 \\
& $(0.43)$ & $(0.36)$ & $(0.43)$ \\
Constant & 0.791 & 1.28 & 1.551 \\
& $(5.60)^{* * *}$ & $(6.52)^{* * *}$ & $(6.79)^{* * *}$ \\
Observations & 4582 & 3664 & 3092 \\
R-squared & 0.04 & 0.03 & 0.03 \\
\hline
\end{tabular}

Absolute value of $\mathrm{z}$ statistics in parentheses.

* significant at $10 \%$; * significant at $5 \%$; ** significant at $1 \%$

\section{Appendix 2}

\section{Appendix 2.1: Chi-Square Test Results}

A Wald test is used for each variable after a full model was run. The tests have two degrees of freedom because they compare three coefficients for each variable.

Appendix 2.1.1: $H_{0}$; The effect of the variable on each group is the same. The coefficients between SPs, PPs and PBs are not significantly different. For each variable in the vector $\mathrm{x}: \beta_{S P}=\beta_{P P}=\beta_{P B}($ See Appendix 2.1.1 below $)$. 


\section{Appendix 2.1.1}

\begin{tabular}{lcc}
\hline Variables & chi2( 2) & Prob $>$ chi2 \\
Capital per worker & 11.3 & $0.0035^{* *}$ \\
Expenses per worker & 0.71 & $0.3997^{*}$ \\
Owners' experience & 1.28 & $0.5273^{*}$ \\
Size & 7.82 & $0.0200^{* *}$ \\
Assets & 9 & $0.0111^{* *}$ \\
Industry wage & 2.01 & $0.3654^{*}$ \\
\hline
\end{tabular}

* The null hypothesis $H_{0}$ cannot be rejected.

** The null hypothesis $H_{0}$ is rejected

Appendix 2.1.2: $H_{0}$; The coefficients for SPs are PPs are significantly equal to 0. For each variable in the vector $\mathrm{x}: \beta_{S P}=\beta_{P P}=0$ (See Appendix 2.1.2 below).

Appendix 2.1.2

\begin{tabular}{lll}
\hline Variables & chi2( 2) & Prob $>$ chi2 \\
Capital per worker & 16.28 & $0.0003^{* *}$ \\
Expenses per worker & 6.18 & $0.0456^{* *}$ \\
Owners' experience & 5.46 & $0.0652^{* *}$ \\
Size & 24.23 & $0.0000^{* *}$ \\
Assets & 7.76 & $0.0207^{* *}$ \\
Industry wage & 1.69 & $0.4304^{*}$ \\
\hline
\end{tabular}

* The null hypothesis $H_{0}$ cannot be rejected.

** The null hypothesis $H_{0}$ is rejected

\section{Appendix 3}

\section{Appendix 3.2}

Probit Regressions on Gender for Firms Operating From Home.

\begin{tabular}{lccccc}
\hline \multirow{2}{*}{ VARIABLES } & $\begin{array}{c}\mathrm{T}=2005 \\
\text { Home- } \\
\text { operated }\end{array}$ & $\begin{array}{c}\mathrm{T}=2006 \\
\text { Home- } \\
\text { operated }\end{array}$ & $\begin{array}{c}\mathrm{T}=2007 \\
\text { Home- } \\
\text { operated }\end{array}$ & $\begin{array}{c}\mathrm{T}=2008 \\
\text { Home- } \\
\text { operated }\end{array}$ & $\begin{array}{c}\mathrm{T}=2009 \\
\text { Home- } \\
\text { operated }\end{array}$ \\
\hline Gender T-1 & $0.0927^{* *}$ & $0.306^{* * *}$ & $0.552^{* * *}$ & $0.646^{* * *}$ & $0.707^{* * *}$ \\
& -0.0417 & -0.0451 & -0.0489 & -0.0527 & -0.0559 \\
Constant & $-0.285^{* * *}$ & $-0.473^{* * *}$ & $-0.667 * * *$ & $-0.738^{* * *}$ & $-0.804^{* * *}$ \\
& -0.0213 & -0.0212 & -0.0216 & -0.0216 & -0.0218 \\
Observations & 4,789 & 4,789 & 4,789 & 4,789 & 4,789 \\
\hline
\end{tabular}

Standard errors in parentheses

$* * * \mathrm{p}<0.01,{ }^{*} * \mathrm{p}<0.05,{ }^{*} \mathrm{p}<0.1$ 
The probit regression above clearly shows that being women-owned increases every yearcoefficients are positive and significant - the probability of being home-operated every year.

\section{Appendix 3.1}

Summary Statistics Details for Financial Variables.

\begin{tabular}{lcccc}
\hline \multirow{2}{*}{ Women -Owned } & Total debt & Total equity & Total equity OO & Total equity NOO \\
& 2004 & 2004 & 2004 & 2004 \\
\hline Obs & 1237 & 1234 & 1237 & 1237 \\
Mean & 54301.08 & 37105.59 & 38528.27 & 12873.97 \\
Std. Dev. & 155150.3 & 117102.3 & 114847.8 & 83119.24 \\
Skewness & 3.314858 & 4.249769 & 4.315237 & 7.516754 \\
Kurtosis & 13.3611 & 20.44443 & 21.18427 & 63.28097 \\
\hline
\end{tabular}

Appendix 3.1 Continued

\begin{tabular}{lcccc}
\hline \multicolumn{1}{c}{ Men -Owned } & Total debt & Total equity & Total equity OO & Total equity NOO \\
& 2004 & 2004 & 2004 & 2004 \\
\hline Obs & 3552 & 3540 & 3552 & 3552 \\
Mean & 79840.29 & 68135.54 & 63690.61 & 26433.73 \\
Std. Dev. & 200220.4 & 179050.3 & 161806.3 & 130710 \\
Skewness & 2.840198 & 3.261514 & 3.340379 & 5.669601 \\
Kurtosis & 10.47714 & 13.39233 & 13.95409 & 36.36728 \\
\hline
\end{tabular}

\section{Appendix 3.3: Chi- Squared Tests.}

$H_{0}$ : The effect of the variable on each group is the same. The coefficients between men and (women-men) are statistically similar.

$$
\beta_{x}=\beta_{x * g}
$$

\begin{tabular}{lcc}
\hline Variables & chi2( 1) & Prob $>$ chi2 \\
Size & 1.01 & $0.31^{*}$ \\
Home-operated & 4.24 & $0.0396^{* *}$ \\
Total debt & 0.83 & $0.3632^{*}$ \\
Total equity & 0.05 & $0.8249^{*}$ \\
Experience & 1.21 & $0.2718^{*}$ \\
Competitive Advantage & 13.36 & $0.0003^{* *}$ \\
\hline
\end{tabular}

* The null hypothesis $H_{0}$ cannot be rejected.

** The null hypothesis $H_{0}$ is rejected. 
VITA

NASSEREDDINE MOHAMAD

2003

2005

2007

2010

\section{B.A Business}

Double Major Finance Real-Estate

Florida International University

Miami, Florida

Masters in Business Administration

Florida International University

Miami, Florida

M. A. Economics

Florida International University

Miami, Florida

Doctoral Candidate in Economics

Florida International University

Miami, Florida

\section{RESEARCH AND PRESENTATIONS}

Nassereddine, Mohamad. "Start-ups Survival Analysis Using the Kauffman Firm Survey: An Analysis of Founding and Current Conditions on Survival." Working Paper, Department of Economics, Florida International University, 2010.

- Paper presented at the annual meeting of the Academy of Management, San Antonio, Texas, August 12-16, 2011

Nassereddine, Mohamad. "Firms' Survival within the Product-Service Spectrum using the KFS:

How the Choice between Product and Service Influences Survival." Working Paper, Department of Economics, Florida International University, 2011.

Nassereddine, Mohamad. "Why are Women-Owned Firms Associated with Higher Failure Rates? A Cross Gender Survival Analysis Using the KFS." Working Paper, Department of Economics, Florida International University, 2011 